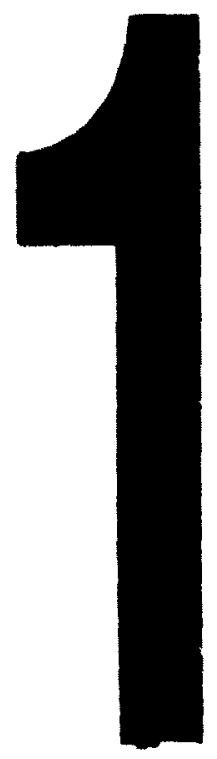

PM-1 31/2"X4" PHOTOCRAPHIC MICAOCOPY TARGET MAS $1010 a$ ANSI/ISO $\# 2$ EOUMALENT

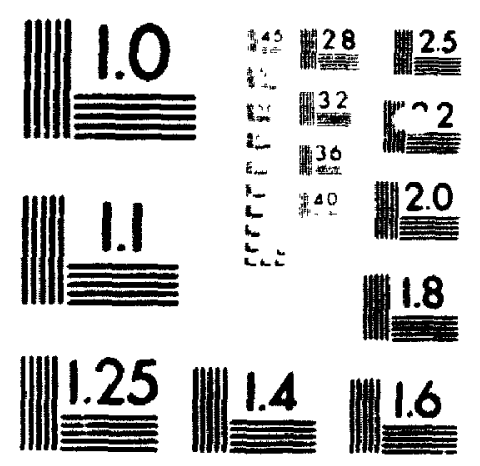


The quality of this microform is heavily dependent upon the quality of the original thesis submitted for microfilming. Every effort has been made to ensure the highest quality of reproduction possible.

If pages are missing, contact the university which granted the degree.

Some pages may have indistinct print especially if the original pages were typed with a poor typewriter ribbon or if the university sent us an inferior photocopy.

Reproduction in full or in part of this microform is governed by the Canadian Copyright Act, R.S.C. 1970, c. C-30, and subsequent amendments.
La qualité de cette microforme dépend grandement de la qualité de la thèse soumise au microfilmage. Nous avons tout fait pour assurer une qualité supérieure de reproduction.

S'il manque des pages, veuillez communiquer avec l'université qui a conféré le grade.

La qualité d'impression de certaines pages peut laisser à désirer, surtout si les pages originales ont été dactylographiées à l'aide d'un ruban usé ou si l'université nous a fait parvenir une photocopie de qualité inférieure.

La reproduction, même partielle, de cette microforme est soumise à la Loi canadienne sur le droit d'auteur, SRC 1970, c. C-30, et ses amendements subséquents. 


\title{
Consumer Socialization Influences on Pre-Purchase Financial Processes: An Investigation of Adolescent Saving and Borrowing
}

\author{
by
}

Paul Rossmann, B.Comm.

\begin{abstract}
A thesis submitted to
the Faculty of Graduate Studies and Research in partial fulfilment of the requirements for the degree of

Master of Management Studies
\end{abstract}

School of Business

Carleton University

Ottawa, Ontario

March 23, 1993

Ocopyright

1993, Paul Rossmann 
The author has granted an irrevocable non-exclusive licence allowing the National Library of Canada to reproduce, loan, distribute or sell copies of his/her thesis by any means and in any form or format, making this thesis available to interested persons.
L'auteur a accordé une licence irrévocable et non exclusive permettant à la Bibliothèque nationale du Canada de reproduire, prêter, distribuer ou vendre des copies de sa thèse de quelque manière et sous quelque forme que ce soit pour mettre des exemplaires de cette thèse à la disposition des personnes intéressées.
The author retains ownership of the copyright in his/her thesis. Neither the thesis nor substantial extracts from it may be printed or otherwise reproduced without his/her permission.
L'auteur conserve la propriété du droit d'auteur qui protège sa thèse. Ni la thèse ni des extraits substantiels de celle-ci ne doivent être imprimés ou autrement reproduits sans son autorisation. 
The undersigned recommend to the Faculty of Graduate Studies and Research acceptance of the thesis

Consumer Sucialization Infuences on Pre-Purchase Financial Processes: An Investigation of Adolescent

Saving and Borrowing

submitted by Paul Rossmann, B. romm., in partial fulfilment of the requirements for the degree of Master of Management Studies

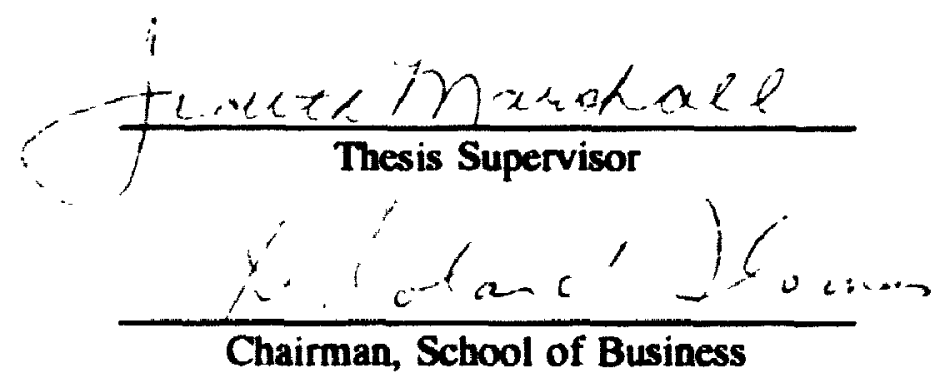

Carleton University

April 23, 1993 


\section{ABSTRACT}

Adolescents have significant wealth at incir disposal and constitutc a recognized current market segment. Recent statistics indicate that North American adoleseents each spend up to $\$ 2,300$ per year, representing a $\$ 6$ billion market in Canada. This thesis des:ribes an investigation into some of the saving and borrowing processes assiccialed with how they manage this money.

The study describes the borrowing and saving behaviour of adolescents and the information sources they use when engaging in this behaviour. Relationships of these: variables with other factors that have been found significant in the consumer sucialization literature (materialism, consumption motivation, socio-economic status, age, and gender) were analyzed. The study extends a previously neglected area of consumer theory, and will be of value to consumer behaviour researchers, financial institutions, consumer educators, public policy makers, and retaikers. 
To Aie 
ACCEPTANCE SHEET $\ldots \ldots \ldots \ldots \ldots \ldots \ldots \ldots \ldots \ldots \ldots \ldots$ ii

ABSTRACT $\ldots \ldots \ldots \ldots \ldots \ldots \ldots \ldots \ldots \ldots \ldots \ldots \ldots \ldots \ldots \ldots \ldots \ldots$

DEDICATION $\ldots \ldots \ldots \ldots \ldots \ldots \ldots \ldots \ldots \ldots \ldots \ldots \ldots \ldots \ldots \ldots$

TABLE OF CONTENTS $\ldots \ldots \ldots \ldots \ldots \ldots \ldots \ldots \ldots \ldots$

LIST OF TABLES $\ldots \ldots \ldots \ldots \ldots \ldots \ldots \ldots \ldots \ldots \ldots \ldots$

LIST OF APPENDICES $\ldots \ldots \ldots \ldots \ldots \ldots \ldots \ldots \ldots \ldots \ldots \ldots$

CHAPTER 1: INTRODUCTION .................. I

CHAPTER 2: RESEARCH PROBLEM $\ldots \ldots \ldots \ldots \ldots \ldots \ldots$

CHAPTER 3: LITERATURE REVIEW $\ldots \ldots \ldots \ldots \ldots \ldots \ldots \ldots$

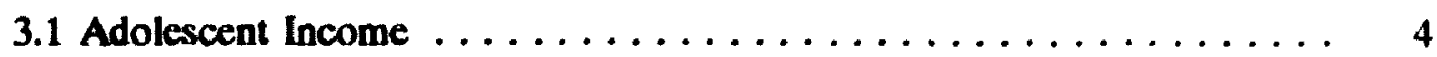

3.2 Consumer Social Learning $\ldots \ldots \ldots \ldots \ldots \ldots \ldots \ldots$

3.3 Adolescent Saving $\ldots \ldots \ldots \ldots \ldots \ldots \ldots \ldots \ldots \ldots$

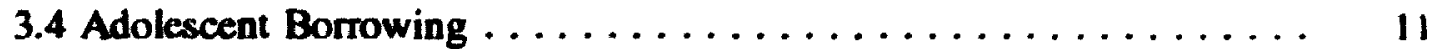

3.5 Adolescent Consumer Behaviour $\ldots \ldots \ldots \ldots \ldots \ldots \ldots \ldots \ldots$

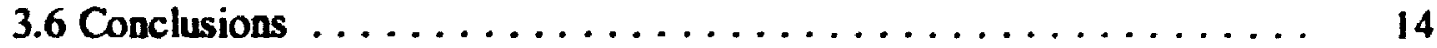

CHAPTER 4. RESEARCH QUESTIONS $\ldots \ldots \ldots \ldots \ldots \ldots$

CHAPTER 5: METHODOLOGY ................. 20

5.1 RESEARCH DESIGN $\ldots \ldots \ldots \ldots \ldots \ldots \ldots \ldots \ldots \ldots$

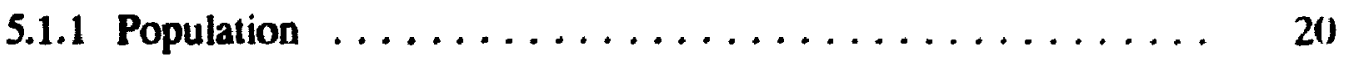

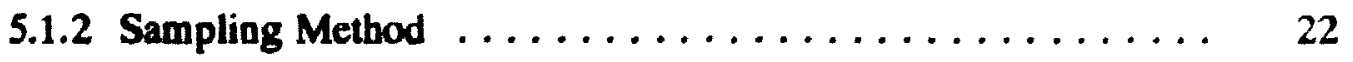

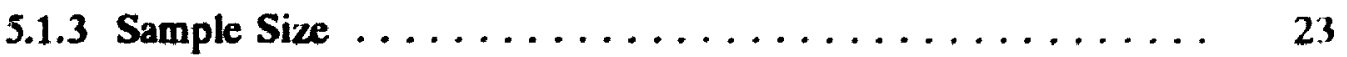


5.1.4 Survey Instrument $\ldots \ldots \ldots \ldots \ldots \ldots \ldots \ldots \ldots \ldots \ldots \ldots$

5.1.4.1 Variable Measurement ............. 25

5.1.4.2 Qualitative Issues $\ldots \ldots \ldots \ldots \ldots \ldots \ldots \ldots \ldots, 28$

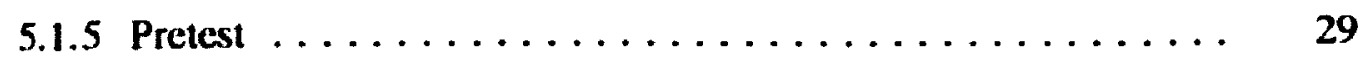

5.2 DATA ANALYSIS $\ldots \ldots \ldots \ldots \ldots \ldots \ldots \ldots \ldots \ldots \ldots \ldots$

CHAPTER 6: FINDINGS $\ldots \ldots \ldots \ldots \ldots \ldots \ldots \ldots \ldots \ldots \ldots \ldots, 31$

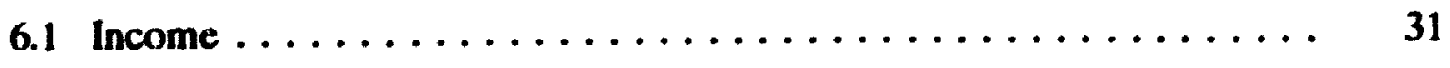

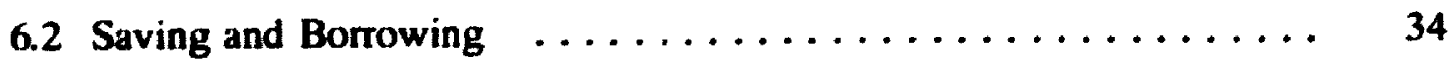

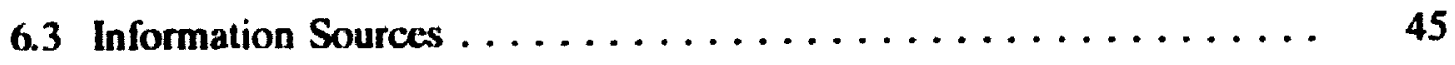

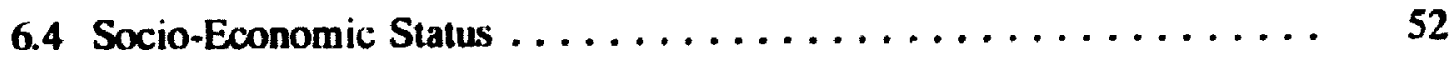

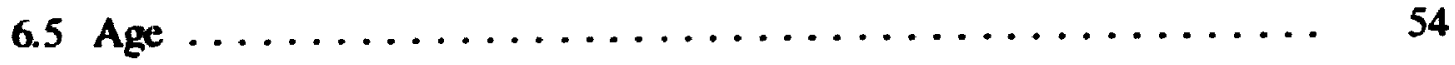

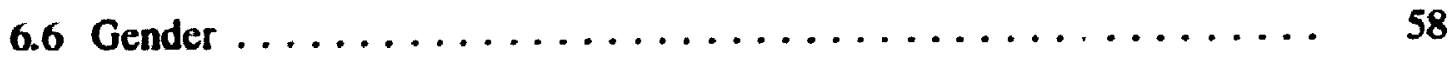

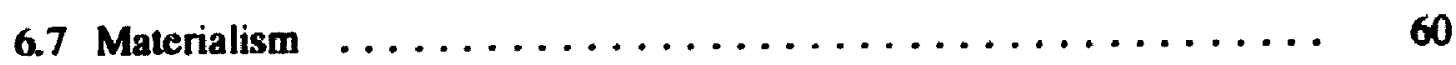

6.8 Consumption Orientation $\ldots \ldots \ldots \ldots \ldots \ldots \ldots \ldots \ldots \ldots, 63$

CHAPTER 7: DISCUSSION AND CONCLUSIONS $\ldots \ldots \ldots \ldots \ldots \ldots 69$

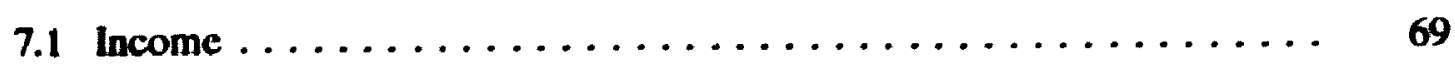

7.2 Saving and Borrowing $\ldots \ldots \ldots \ldots \ldots \ldots \ldots \ldots \ldots \ldots \ldots, 71$

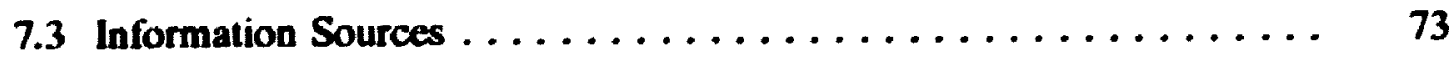

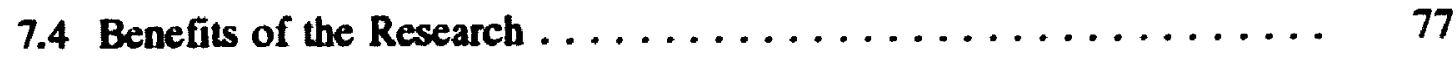

7.5 Limitations of the Research $\ldots \ldots \ldots \ldots \ldots \ldots \ldots \ldots \ldots, 80$

7.6 Conclusions and Directions for Future Research $\ldots \ldots \ldots \ldots \ldots .80$

REFERENCES $\ldots \ldots \ldots \ldots \ldots \ldots \ldots \ldots \ldots \ldots \ldots \ldots \ldots \ldots \ldots \ldots \ldots, 82$ 


\section{LIST OF TABLES}

Table

Page

1 Description of Ottawa-Carleton School Boards $\ldots \ldots \ldots \ldots \ldots \ldots$

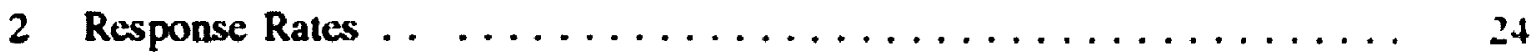

3 Amounts and Sources of Income $(6$ months $) \ldots \ldots \ldots \ldots \ldots \ldots \ldots$

4 Amounts and Sources of Income $(1$ month) $\ldots \ldots \ldots \ldots \ldots \ldots \ldots$

5 Extent and Methods of Saving $\ldots \ldots \ldots \ldots \ldots \ldots \ldots \ldots \ldots \ldots$ is

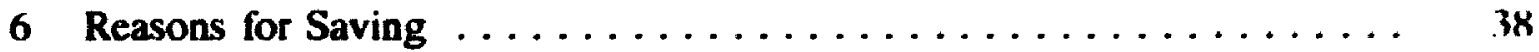

7 Extent and Methods of Borrowing $\ldots \ldots \ldots \ldots \ldots \ldots \ldots \ldots$

8 Summary of Questions on Credit Card Use . . . . . . . . . . 43

9 Reasons for Borrowing (6 months) $\ldots \ldots \ldots \ldots \ldots \ldots \ldots \ldots, 44$

10 Extent of Information Seeking by Saving and Borrowing Mechanisms ... 4x

11 Extent of Reliance on Saving and Borrowing Information Sources .... 49

12 Correlation Matrix for Saving and Borrowing Information Sources and Other Select Variables . . . . . . . . . . . . . . . . . . . \$ 50

13 Saving and Borrowing Information Needs $\ldots \ldots \ldots \ldots \ldots \ldots \ldots$

14 Associations Between Socio-Economic Status and Select Dependent

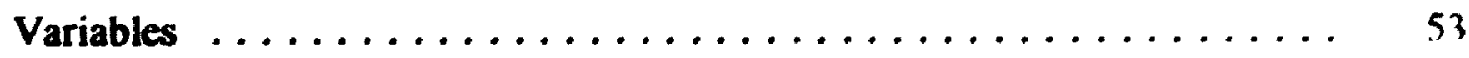

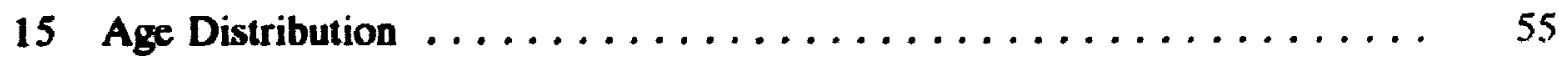

16 Associations Between Age and Select Dependent Variables ........ 56 


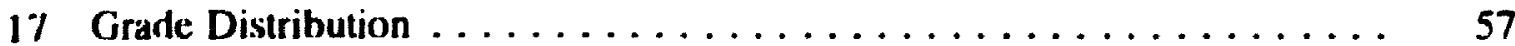

18 Gender Distribution by School $\ldots \ldots \ldots \ldots \ldots \ldots \ldots \ldots \ldots \ldots, 58$

19 Associations Between Gender and Select Dependent Variables ....... 59

20 Associations Between Materialism and Select Dependent Variables ..... 62

21 Associations Between Social Motivation for Consumption and Select Dependent Variables . . . . . . . . . . . . . . . . . 67

22 Associations Between Economic Motivation for Consumption and Select Dependent Variables $\ldots \ldots \ldots \ldots \ldots \ldots \ldots \ldots \ldots \ldots \ldots$ 


\section{LIST OF APPENDICES}

Page

Appendix A: Research Questions . . . . . . . . . . . . . Y)

Appendix B: Survey Instrument $\ldots \ldots \ldots \ldots \ldots \ldots \ldots \ldots \ldots \ldots$

Appendix C: Letter of Parental Consent $\ldots \ldots \ldots \ldots \ldots \ldots \ldots$

Appendix D: Table of Occupational Social Status $\ldots \ldots \ldots \ldots \ldots \ldots$

Appendix E: Research Schedule $\ldots \ldots \ldots \ldots \ldots \ldots \ldots \ldots \ldots \ldots \ldots$

Appendix F: Cost Schedule . . . . . . . . . . . . . . . 112 


\section{CHAPTER 1: INTRODUCTION}

Households have traditionally been viewed as cconomic eaming and consumption units within which resources have been shared equitably between family members. In reality, however, funds are carned and spent by individuals. Only recently have researchers begun to study the distribution of wealth among members of households. Pahl (1989) noted that the topic has been practically unmentioned by researchers, except those who have noted how litte we know about it:

We have no data about the flows of income between people within houscholds (Central Statistical Office, 1979, quoted by Pahl, 1989).

We do not know except in the sketchiest fashion how income is distributed between people within families (Young, 1977, quoted by Pahl, 1989).

Since the control of money within families is likely to be a significant variable in family spending patterns, research in the area of the intra-family economy is important. As the impact of working women becomes more marked, so too should the impact of the escalating number of adolescents who have been joining the labour force: it is estimated that up to 80 percent of older adolescents work for pay, and almost all have some form of income. As a review of the literature will reveal, the impact of these changes has not been adequately examined in terms of how they effect the control of resources within the family, especially those processes which precede actual purchase decisions. 
Adolescence is defined as the life-cycle stage between puberty and the time when perple take on the responsibilities of adults (Greenherger, 1986; Cambell. 1969). Mist research studies seem to have operationalized this definition to include those between the ages of about 14 and 19 .

This thesis describes a study that examined some of the processes which precede the purchases of older adolescents (i.e., saving and borrowing), and the roles that parents. friends, advertising, salespeople, bank telkers, and other information sources play in influencing those processes. The thesis is divided into 6 chapters. Chapter 2 outlines the research problem, which is further clarified and supported by a review of the rekevant literature in Chapter 3, and a statement of the research questions in Chapter 4. The research methodology is outlined in Chapter 5, and is followed by a description of the findings in Chapter 6, and a discussion and conclusions in Chapter 7. 


\section{CHAPTER 2: RESEARCH PROBLEM}

Adolescents have significant wealth at their disposal and constitute a recognized current market segment. During 1991 Canadian 14-year-olds spent an average $\$ 1,400$ each; 15 to 17-year-olds spent \$2,300 each; and 18 to 19-year-olds spent an average of $\$ 4,200$ each (Marketing. 1991b). There were more than 2.5 million teenagers in Canada in 1992, and they spent an estimated \$6 billion on consumer products annually (Marketing, 1991b). This thesis explores the processes preceding adolescent spending decisions in terms of the information sources they use when saving and borrowing.

The study is valuable to a wide range of people: academics interested in consumer behaviour know little about pre-purchase behaviour; financial institutions and retailers, which deal directly with these finances, have an immense stake in this aspect of adolescent behaviour; and consumer educators and public policy makers are concerned about the extent to which adolescents work, and how they behave as consumers. The purpose of the research described in this thesis was to explore adolescent financial behaviour and thereby to identify some of the issues about which these people should be concerned. 


\section{CHAPTER 3: LITFRATURE REVIEW}

Marketing literature concerning children and adolescents has viewed them in three ways. Firstly, as an influential market, youngsters frequently influence the purchases of their parents. Secondly, as a current market, they have a significant amount of direct spending power. Finally, as a future market, children and adoleseents are recongnized as being the main consumers of years to come. This study deals with adou scents as a currett market.

Recent non-academic literature which illustrates the significance of this market is reviewed first in Section 3.1. Given the vast amounts of money that adolescents control, the importance of questions as to how they manage that money hecomes apparent. What is known about this money management is reviewed in the literature on adoleseent saving and borrowing in Sections 3.3 and 3.4. Adolescent consumer behaviour literature is then reviewed in Section 3.5. Since much of the aforementioned literature is based on sccial learning theory, consumer socialization literature is summarized early in the literature review, in Section 3.2 .

\subsection{Adolescent Income}

Economic need formerly drove youngsters to work, and it was mainly lower class adolescents who were employed (Reubens, 1983; Mortimer, 1991; Greenberger and Steinberg, 1986). But in recent years, in spite of the increasing affluence of North American society, adolescents have continued to work, and youth-work has largcly become a middle class phenomenon (Mortimer, 1991). There has been considerable 
debate about whether the benefits of adolescent work outweigh the drawbacks. Research which extols the virtues of employment for character development (Greenberger, 198; Greenberger, 1984; D'Amico, 1984) is countered by researchers who claim that work is too much of a burden on the time and energy of adolescents. They claim this time and energy would be better spent on other psychological tasks (Greenberger, 1986; Cole, 1980). Although the debate about the merits and drawbacks of youth-work continues (D'Amico, 1984, Greenberger, 1988), working among North American teenagers has continued to grow more prevalent.

Based on 1986 Census data, Statistics Canada (1989a, Table 3-1) reported that in Canada 48.4 percent of 15-19 vear old males and 45.6 percent of females were employed. A rash of recent market research studies indicate that up to 75 percent of adolescents are working. The disparity between the market research estimates and official Statistics Canada statistics deserves some attention.

Estimates of teen-age employment have been found to be higher when measured by self report (Mortimer, 1991; Greenberger, 1986; Bachman, Johnston, and O'Malley, 1987). Grenberger (1986), for example, reports differences of up to 30 percent for self-report versus official statistics. Official statistics measure the numbers of people who are employed as of a specific date, instead of over a period of time. The 1986 Labour Market Activity Survey (LMAS) of Statistics Canada, however, reported the number of people who were employed at any time throughout the year. This profile of the labour 
market experience of Canada's youth (1989, p.8) reported that almost 80 percent of 16-19 year-olds were employed at some time during the year. The average periond of employment was 31 weeks. Bresnick (1984) also described the youth latxour market as transitional and temporary.

While these figures are more in-line with other self-repon surveys, even they have likely underestimated the true level of working adolescents: the IMAS reported that $\%$ pereent of employed youths were employed in paid-worker jobs, i.e., in jobs "...where the work was done in an employer-employce relationship" (Statistics Canada, 198\%, p.9). Babysitting and other odd jobs that do not conform to this definition would therefore not have been included.

Even valid measures of teenage employment would not truly refket the amount of money that teenagers have at their disposal. Not only do adolescents receive money from parttime jobs, but they also receive it from their parents. Recent market rescarch studies indicate that up to $\mathbf{4 0}$ percent of adolescents have regular allowances, and over $\mathbf{4 0}$ percent receive money from their parents "when necessary" (Bachman, 1986; Marketing, 19)1b; 1989; 1991a). Since most necessities are provided by parents, all of this income is typically available for discretionary spending (Bachman, 1983; Bachman, Johnston, and O'Malley, 1987; Globe and Mail, 1989). 
These studies revealed that 13 -year-olds spend roughly $\$ 25$ per week $(1,400$ per year) and 18 to 19-year-olds spend an average of $\$ 75$ dollars per week $(4,200$ per year $)$. This spending represents over $\$ 40$ billion in the United States and over $\$ 6$ billion in Canada. Teenage spending in Canada is expected :o increase to $\$ 10$ billion per year by the end of the decade (Bachman, 1986; Marketing, 1991b; 1989; 1991 a, Financial Post, 1989; Globe and Mail, 1991). This literature demonstrates the relevance of research that is directed at gaining an understanding of how adolescents manage and control this vast amount of wealth.

\subsection{Consumer Social Learning}

Consumer socialization research has mainly focused on children between the ages of 4 and 12, and has tended to address the issues of: 1) What children know and think about the market place, 2) the socialization agents from which children learn consumer behaviour, and 3) the nature and extent of children's consumer behaviour (McNeal and Ych, 1990). With the work of McNeal in the 1960 s, the beginnings of the processes by which children begin to earn, save, and spend money were uncovered. The social kearning model upon which this work was based explained learning in terms of various sources of influence known as socialization agents. Agents that were studied included parents, siblings, peers, teachers, advertisements, and stores. Socialization theory assumes that behaviour patterns are formed as a result of socialization agents applying forces or influences to children in various social settings (McNeal, 1987). 
Ward, Wackman, and Wartella (1977) followed McNeal's work with a landmark study and synthesis of cognitive development and social learning theory. this theory's application to both information processing and behaviour. and family influences on children's consumer learning.

The work of Ward, et al. and McNeal was closely followed and developed by Getorge Moschis and a number of his colleagues, who, in the late 1970s and throughurut the $19 \mathrm{x}(\mathrm{k}$. published a series of works which focused on middk and high school adolescents. Although cognitive development models suggested that all socialization occurred by the age of 15, social learning models suggested that adolescents in middle and carly high school were in the most critical period of consumer socialization (Moore and Stephens. 1975), when they develop social skills, self-concepts, and conceptions regarding decisions and their outcomes (Cambell, 1969).

Consumer social learning literature demonstrated that even very young children were both earners and spenders. Their willingness to spend was apparent from the fact that they spent almost everything that they received (McNeal, 1986; Ward, Waukman, and Wartella, 1977). A large part of the literature dealt with descriptions of children's income and expenses, their attitudes towards brands, advertising etc. In an effort to understand how children learn consumer attitudes and behaviour, relationships were sought between these attitudes and behaviours, and interactions with various socialization agents. 
Consumer social learning will be discussed further in the contexts of adolescent saving, borrowing, and consumer behaviour.

\section{Adolescent Saving}

Children learn how to save in the late elementary school years, when their incomes grow and the increasingly costly products they desire require saving. By the time children reach adolescent years they are engaging in regular and substantial saving behaviour (Ward, Wackman, and Wartella, 1977). Parents are likely to influence this behaviour significantly. McNeal (1987) reported that half of the savings of 4 to 12 year-olds are put in some sort of savings account (sometimes bonds) for them, while the remainder is kept in the home, presumably for spending

Long-term (1 month or longer) saving behaviour was found more frequently among younger children than among older children, even though older children were more aware of the value of saving (Ward, Wackman, Wartella, 1977). McNeal (1987) explained saving among younger children as being a function of not having extensive opportunity to spend. He also found that savings as a percentage of income decline with the age of older children, who continually discover new wants and have increased opportunity to spend.

Tootelian and Windeshausen's (1976) replication of a ten year-old study revealed that adolescents saved to a larger extent in 1976 than they did in the previous decade. 
Although this study is dated, more recent surveys have found that adolescents are saving more today than ever before. In 1989 ctildren werce saving 30 percent of their income (McNeal, 1990). Only 4 years earlier the same group was saving only 11 percent of their income (McNeal, quoted by Fortune, 1989). McNeal (1990) noted that the increase was "remarkable," and speculated that purents could be providing children with more monity in order to encourage more self-reliant money management at an earlicr age.

Increases in levels of saving among adolescents are ilue to the increasing materialism and expensive tastes of youths, who have been finding that they have to save extensively in order to be able to afford the products that they want to buy (Toxtelian and Windeshausen, 1976). It was reported that adolescents save for products such as travel to Europe, cars, stereos, and televisions (Financial Post, 1989; Bachman, 1987). Indeed, it has been reported that $47 \%$ of teenagers maintain a savings account for big tickel items (Marketing, 1989). The extent of savings is highly correlated with age. By the first year of university, reported Marketing (1988), 67 percent of students have savings accounts and 90 percent have chequing accounts. Twenty percent these same students owned government savings bonds, and 12 percent owned stock.

On the other hand. Bachman (1983) reported that approximately 50 percent of high schox)l seniors do not do save any of their income for future education, and 50 percent do not save for any other long range purposes. Ten percent were found to save more than half 
of their carnings for future education, and 8 percent were found to save more than half for other long range purposes.

While it seems that most adolescents save for short periods, and that the motive for these savings is clearly consumption, the significant amounts that they are saving have drawn the attention of banks: special savings accounts and CDs (certificates of deposit) for youths up to the age of 21 have recently been appearing (Fortune, 1989; Schindler, 1989). A bank exclusively for children recently opened in Colorado (Stipp, 1988; Murphy, 1987).

\subsection{Adolescent Borrowing}

Abramovitch, Freedman, and Pliner (1991) studied the credit versus cash spending of 6-10 year old c'::idren. In this experiment, they allowed children to spend 4 dollars on credit in a simulated shopping environment. A control group of children was given 4 dollars in cash. Both groups were told that they could keep the money that they did not spend. These researchers found that children who did not receive allowances spent more in the credit than in the cash situation. No differences in credit and cash spending were found with those children who did receive allowances. Neither age nor any other social variables were found to be significant. Although the children used in this experiment were young, the amount of money they were dealing with was small. The study indicated that the understanding of debt is related to financial experience. It is possible that adolescents, who have more financial experience, but also are likely to deal with more significant kevels of debt, might behave similarly along the same variables. Other 
variables which usually predict financial experience (age, socioeconomic status) arce likely to be more significant with older adolescents.

Recent marketing research studies indicate that at least 12 percent of teenagers have access to a credit card (Hauser, 1986). Credit card ownership was highest (35 percent) among 18 and 19 year-old girls. Marketing (1988) reported that by the first ycar of university, slightly more than one third of Canadian students have their own credit cards. Hauser (1986) reported that credit card use is directly and positively correlated to family income, and that, at least for teenage girls, clothing and heath and heauty aids are the major categories of credit card purchase. No studies have indicated the degree to which adolescents use bank loans or other forms of debt (e.g., hans from parents, pawnbroker services).

\subsection{Adolescent Consumer Behaviour}

Consumer learning theory has been used to a great extent in studies of adolescent consumer behaviour. These studies, noted Moschis (1978a), have typicaliy been of two types: those which examine teenagers responses to consumption-related variabies and those which focus on teenage purchasing processes. A brief summary of each follows.

\section{Consumption-Related Variables:}

This significant body of research has examined adolescents' consumption-rclated thoughts and behaviours such as: their attitudes toward spending, prices, brands, and advertising; 
and their purchasing habits. The earlier studies (see Cateora, 1963; Phelan, 1969) were mostly exploratory or descriptive and often lacked strong theoretical bases (Moschis, 1978a). The weaknesses in the literature which appeared in the 1960 s and 1970 s were mitigated by Moschis (1978a) when he described variations in responses to consumptionrelated variables (brands, stores, salespeople, prices, and advertising) in terms of factors related to theories of consumer socialization, which be borrowed from the work of Ward, Wackman, Wartella, and McNeal. In general, Moschis found age and motivation for purchasing (social motivations and cconomic motivations) to be the strongest predictor variables of the attitudes he studied.

\section{Purchasing processes}

Research on the purchasing processes of adolescents (see Moschis, Moore, and Stephens, 1977; and Gilkison, 1973) has excluded examination of stages in the decision making process preceding the actual purchase (Moschis, 1978a). Instead, it concentrated on purchasing role structures (i.e., individuals involved in the physical act of purchasing products for teenagers) and other aspects of the social environment thought to have an impact on the purchasing process of adolescents (Moschis, 1978a). For example, Tootelian and Winieshausen's (1976) study described sources and amounts of adolescent income as well as the shopping and purchasing habits of adolescents. Gilkison (1973) studied and described the reference sources that were of greatest importance in influencing buying decisions of teenagers. He found that in general the use of parents as a frame of reference in purchases was less prevalent than it had been 10 years earlier, 
while the role of peer influence had increased. This, however, was not truc of all product classes that were investigated. In a similar study, Moschis, Moore and Stephens (1977) made similar conclusions. They explained family member involvement in adoleseint purchases as a function of socio-economic risk (social visibility and price of pronlucts) present in each purchasing situation. Tootelian and Windeshausen (1976) atso) corroborated these findings. Moschis (1978a) investigated the extent to which adokeseents seek information before purchasing, and the sources from which it is sought.

\subsection{Conclusions}

The literature demonstrates that adolescents earn and spend quite significant amounts of money. Existing literature on adolescents is very dated (much is over 10 years old), and there have been no controlled and systematic investigations of how they manage moncy prior to spending. Yet adolescent saving and borrowing are notable phenomena. Whike credit card use has been found to be widespread, there have been no investigations of other sources of debt that adolescents might use. Little is known about what information sources adolescents use when borrowing and saving Insights regarding these neglected aspects of adolescent consumer behaviour could be especially beneficial to consumer behaviour researchers seeking to deepen the understanding of adokescent consumcr behaviour, to financial institutions seeking to service this market, to consumer educators seeking to educate this group, and to public policy makers and retailers. 


\section{CHAPTER 4. RESEARCH QUESTIONS}

The rescarch questions which are put forward here were derived from the void in consumer behaviour literature pertaining to aspects of the adolescent purchasing process preceding actual buying. They are supported, however, by the theory that has been described in the foregoing literature review.

Those studies in adolescent consumer behaviour which focused on adolescent purchasing processes (c.g. Moschis, Moore, and Stephens, 1977; and Gilkison, 1973) dealt with the reference sources, role structures, and information sources that youngsters use when purchasing products. Reference sources were defined in those studies as the perceptual contcxts within which adolescents make their purchase decisions. Role structures were defined as those people physically present at the time of purchase Moschis, Moore, and Stcphens, 1977). Information sources were defined as the sources from which adolescents actively seek information before purchasing.

Of interest would be an investigation of these same concepts, but as they relate to borrowing and saving rather than purchasing. These concepts are important because they are likely to influence borrowing and saving behaviour. While the study of all three of these concepts would be valuable, only information sources were investigated in this research study. Information sources were of particular interest because they encompass reference sources and role structures : reference sources and role structures are particular types of information sources. 


\section{Information Sources}

Know ledge about consumers' exposurc to information is important fir understanding their interpretation processes a cognitive phase in the buying process (Peter and ()lison, 1987). Exposure to information can be intentional, as when the exposure is the result of their own intentional goal-directed behaviour; or it can be accidental, when intirmallun is randomly acountered as consumers move through their environments (Peter and Olson, 1987).

"Information seeking" was identified by Moschis (1978b) as a complex con.umer skıll. He measured it in terms of the active information search of adoleseents. The information sources associated with this construct are operationally defined here as sources from which information is obtained prior to making a borrowing or saving decisiun in order to help make the decision. Those influences that have been investigated in the past included parents, friends, salespeople, consumer reports, television ads, and newspaper and magazine ads (Moschis. 1978b). As an extension of past work, the lollowing question was asked:

Q1: Do any of the following serve as information sources for adolescent saving and borrowing: parents, friends, bank tellers or salespeople, brochures, newspaper or magazine ads, television ads, books, or consumer reports? 


\section{Consumption Orientation}

Moschis, Moore, and Stephens (1977) found that the degree of parental involvement in purchases increased with the socio-economic risk that was present in each purchasing situation. Measures of this risk are not likely to be constant for a given purchase for every teenager. Rather, they are likely to be relative to the predisposition of each individual. For example, while a purchase may represent a high social risk to a person with socially oriented consumption motivations, it may not be for a person whose consumption motivation is more cconomic. Moschis used the concepts of materialism and consumption motivation (economic vs. social) in order to account for consumer predisposition. He defined these concepts as follows:

Materialism: An orientation emphasizing possessions and money for personal happiness and social progress.

\section{Consumption Motivation:}

Social: Cognitive orientations concerning the importance of conspicuous consumption and self expression via conspicuous consumption.

Economic: Cognitive orientations concerning the importance of product functional and economic features, orientation towards comparison shopping, and significant discriminating attributes. 
This led to the question of whether predispositions and values affect either borrowing and saving behaviour or the sources adolescents rely upon when secking information ahout borrowing and saving.

Q2: How do materialist values affect adolescent borrowing and saving behaviour and information secking?

Q3: How do consumption motivations affect adolescent borrowing and saving behaviour and information sceking?

\section{Socialization}

The socialization perspective that has been taken with adolescent consumer behaviour studies in the past also seemed appropriate for this study. Indeed, many of the variables used in socialization research were likely to be relevant for describing and understanding adolescent borrowing and saving. Analysis of these variables would indicate how this behaviour relates to the factors that have been found significant in investigations of other parts of the purchasing process. Significant differences have been found in consumer behaviour along the variables of gender, age, and socio-economic stalus. Therefore, the following questions were asked:

Q4: Are there gender differences in adolescent saving and borrowing behaviour or information seeking?

Q5: Are there age differences in adolescent saving and borrowing bchaviour or information seeking? 
Q6: Are there socio-economic differences in adolescent saving and borrowing behaviour or information secking?

\section{Borrowing and Saving Behaviour}

In order to answer all of the above questions, adolescent borrowing and saving behaviour needed to be described. Therefore the following questions were asked:

Q7: How can adolescent borrowing and saving be described?

i) Why do adolescents save?

ii) Why do adolescents borrow?

iii) What is the extent of adolescent saving?

iv) What is the extent of adolescent borrowing?

v) What saving mechanisms do adolescents use?

vi) What borrowing mechanisms do adolescents use?

The research questions are summarized in Appendix A (page 90). 


\section{CHAPTER 5: METHODOLOGY}

In order to answer the above questions a cross-sectional. ex post facto field survey was designed. It was administered through the public school system in the Ottawa-Carleton region. The research design is described in Section 5.1. Procedures used in data analysis (frequencies, crossclassifications, and Goodman-Kruskal lests of association) are described in Section 5.2 .

\section{S.1 RESEARCH DESIGN}

The research design is describer! here in terms of the population, sampling frame, sample method, sample size, survey instrument, pretest, and fieldwork procidures.

\subsubsection{Population}

The population from which the sample was selected can be described as follows:

$\begin{array}{ll}\text { Element: } & \text { Students in the 10th through 13th grades } \\ \text { Primary Unit: } & \text { Public high schools } \\ \text { Secondary Unit: } & \text { "Home room" classrooms } \\ \text { Extent: } & \text { Ottawa-Carleton } \\ \text { Time: } & \text { November } 1992\end{array}$

Advantages of accessing subjects through the school system were that it represented the elements of interest directly and relatively completely. Furthermore, the use of the sch(x)l 
system afforded the opportunity of surveying a large number of people conveniently and at reasonable cost. Disadvantages of using the school system were mainly that some control over data collection was lost, and simple random sampling methods could not usce. The overall advantages of using the school system for accessing respondents outweighed the disadvantages, and the process of collecting data through the school system was initiated.

Research applications were submitted to the four english school boards in the OttawaCarleton region (the first 4 boards listed in Table 1). All but the Carleton Roman Catholic Separate School Board approved the research application. The largest two school boards the Ottawa Board of Education and the Carleton Board of Education were chosen as the sampling base. Since $70 \%$ of all students study under schools under the jurisdiction of these 2 boards, the students of these two school boards were considered more representative of the general population. Data were not collected from the Ottawa Roman Catholic Separate School Board, since it was smaller and the effects of a religious bias were unknown. Minor changes to the cover letter and questionnaire were requested by both school boards, and inclusion of a parental consent form was required by the Ottawa Board for respondents who were less than 18 years old. 


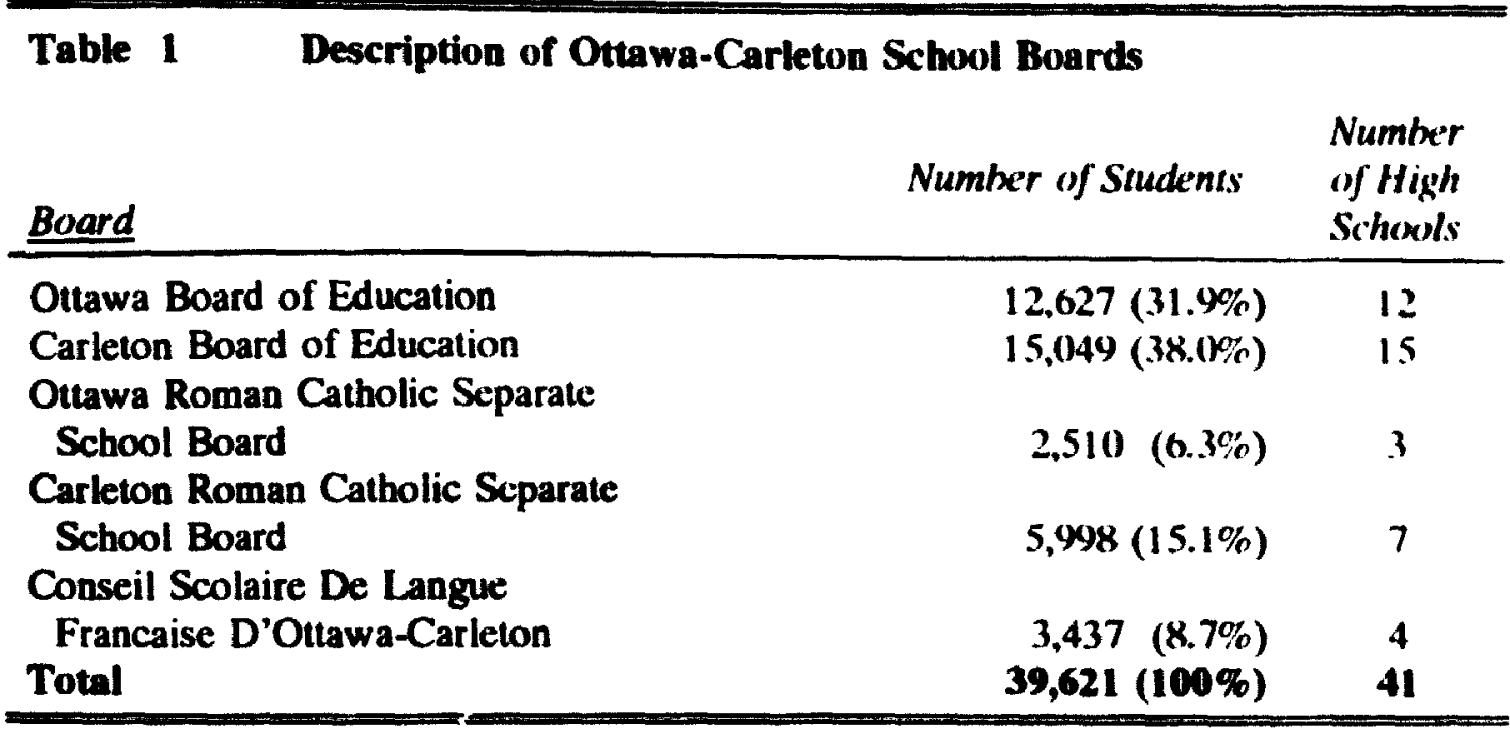

\subsubsection{Sampling Method}

The two participating school boards were asked to randomly identify schools which could be requested to participate in the study. Seven schools were identified by the Carleton Board, and 2 by the Ottawa Board. Vice-principals were contacted and asked to participate: 6 of the Carleton Board schools agreed to participate, and both of the Ottawa Board schools agreed to participate. The one school that declined to participate cited previous commitment to other research studies as the reason for refusal.

Approximately 120 questionnaires were distributed to each of the Carleton Board schoxis, and one of the Ottawa Board schools; the second Ottawa Board school agreed to take 350 questionnaires. Each school was asked to distribute the questionnaires to one homeroom class from each of the 10th, 11th, 12th, and 13th grades. The larger Ottawa Board school was asked to distribute to an equa! number of classes from each grade. 
Copies of the instrument were distributed by teachers in selected classes of the schools that agreed to cooperate with the study. Respondents were asked by their teachers to retum the instruments in class within about 1 week of their receiving them. No control could be maintained over data collection by the researcher once the questionnaires had been delivered to schools. Teachers could not even be asked to remind or encourage students to return the instruments, as the only contact was through the vice-principles, and they were often very difficult to reach.

Cluster sampling is often used for its administrative advantages, although it can result in distortions of statistical tests (Rao and Thomas, 1988). Cluster sampling was needed for this study because the alternative simple random sample design would have placed too much of an administrative burden on the schools.

\subsubsection{Sample Size}

Approximately 1115 questionnaires were delivered to schools; but only $863(75 \%)$ of the questionnaires that were delivered were actually distributed to students. Secondary sample units (classes) had a size of approximately 25 respondents. The final sample was comprised of 32 classes from a total of 8 schools.

Table 2 summarizes the response rates from each school that participated in the study. An average response rate of $\mathbf{4 3}$ percent yielded 371 returns. A lower response rate was expected from the Ottawa Board schools due to its requirement of written parental 
consent for each participant. The variance in response rates between schouls of the Carleton Board was most likely a function of the commitment cach school and more importantly, each teacher- gave to the project.

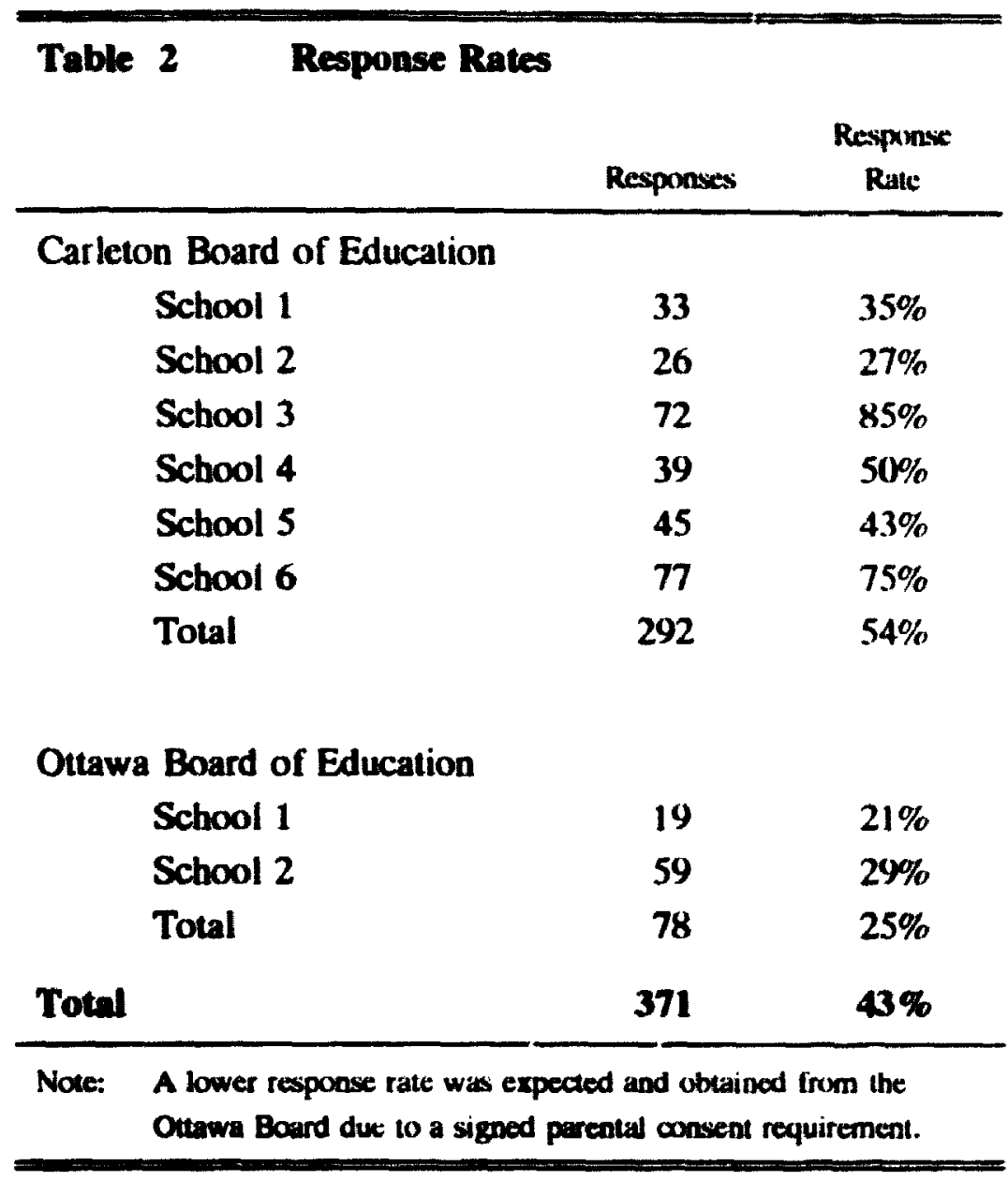

\subsubsection{Survey Instrument}

A self-administered questionnaire was used for data collection. A copy of the questionnaire is provided in Appendix B (page 91). Tested questions from past studies 
were used wherever possible. Specifics of how variables were measured are discussed in Section 5.1.4.1. Issues that were of concern in choosing the data collection instrument included the age of respondents and the nature of the research topic. Each of these issues is discussed in Section 5.1.4.2.

\subsubsection{Variable Measurement}

The major variables that were measured included: saving and borrowing behaviour, information sources used when saving and borrowing materialism, consumption motivation, socio-economic status, income, age, and gender. Approaches to measurement for each variable are outlines below.

Extent, Method, and Purpose of Borrowing and Saving were measured through a seies of clnsed-ended questions that asked whether or not respondents had borrowed or saved in a variety of ways, and solicited the balances of current savings and debt for each method (questions 9 and 17 . The purpose of borrowing and saving was measured by asking respondents what they were saving and borrowing for (questions 12 and 24).

Information sources that adolescents used when borrowing and saving were measured through 2 questions that were adapted from the questions used by Moschis (1978b) to measure information sources used by adolescents in the purchasing context. Information sources included: parents; friends; bank tellers and salespeople; and books and consumer reports; brochures, and newspaper and magazine ads; and television ads (questions 13 and 
23). The questions solicited binary responses about sources used by respendents for information or advice before deciding to borrow and save via each of 12 methouk of borrowing and 8 methods of saving.

Materialism was measured with a 6 item index (question 6) that was developed by Moschis (1978b). This materialism index was used because it was short and had heen used by Moschis on a similar sample.

Moschis reported that this scale had a reliability coefficient of $\alpha=.60$ for his 1978 study of adolescent consumer behaviour. The reliability coefficient for the present study was found to be slightly lower $(\alpha=.56)$.

Economic motivation for comsumption was defined and operationalized using Moschis" (1978b) scale; it was adapted by adding the product "steres" in place of Moschis" "pocket calculator" (question 7). This change was made because calculators are less expensive and more commonplace than they were at the time Moschis did his restarch. Moschis (1978b) reported a reliability of $\alpha=.69$ for this scak. An $\alpha$ of .87 was found in the present study.

Social motivations for consumption were likewise defined and operationalized using Moschis' 1978(b) scak, with the same aforementioned change of "proket calculator" to 
"slereo" (question 7). Moschis (1978b) reported a reliability of $\alpha=.85$ for this scale. An $\alpha$ of .83 was found in the present study.

Socio-economic Status was measured based on the education, income, and occupational status of parents. The use of these three items is the most common approach of sociocconomic status among sociologists (Powers, 1983). Moschis (1978b) used a sociocoonomic index (the Duncan SEI) which used the same three constructs to measure sociocconomic status, but only the father's-and not the mother's - occupation was used. Studies of socio-economic status measurement criticized Duncan's SEI (Featherman and Suvens, 1982; Cooney, Clague, and Salvo, 1982) on this account. Their recommendations vary, however, since women still tend to be concentrated in the middle range of occupations, and since gender differences persist between full- and pantime workers (Powers, 1982). Featherman and Stevens (1982) recommend that a male-based index is tire most practical for the time being; while Cooney, Clague, and Salvo (1982) recommend a total labour force based index. Boyd and McRoberts (1982) conclude that the choice of an index for measuring status attainment is "very much up to the discretion of the researcher."

An index of socio-economic status was constructed for this study from the education of cach parent, family income, and the occupational status of the parent with the higher status. Mothers had occupations of higher status in $12 \%$ of the cases. The occupations of each parent was measured through an open-ended question (question 34), as 
recommended by Moschis (1978b), and coded on the 7-point status index of Helitzer (1979). Education was classified into one of 6 catcgories, ranging from "High school or less" to "Post-graduate degree(s)" (question 33). Family income was measured in 5 broad categories (question 35).

\subsubsection{Qualititive Issues}

Helitzer (1979) reported, based on marketing research studies, that lengthy mall questionnaires can be successfully used with older youths. He noted that their patience with interviews is notably longer than that of adults, and that fatigue with long questionnaires seems virtually non-existent. While it has been noted (Pahl, 1989) that the financial arrangement of individuals are among the most private of subjects, it has also been found that youths will express themselves to researchers with a great amount of candour, even on sensitive research topics (Helitzer, 1979).

Neither the age of respondents nor the nature of the research topic were expected to negatively affect the appropriateness of the chosen data collection method: indeed, no evidence of fatigue was found in the completed questionnaires; and the large proportion of questionnaires that were returned in unsealed envelopes (more than $50 \%$ ) was evidence that respondents did not consider the information that they had volunteered as overly sensitive. 


\subsubsection{Pretest}

The instrument was pretested on students who graduated from high school in the Spring of 1992, and who were enrolled at Carleton University in the fall term of the same year. Two sections of a first year course in the School of Business were chosen for the pretest. Students were asked at the beginning of class if they would volunteer for the pretest, and questionnaires were returned before the following 2 classes. Of the 35 distributed questionnaires, 12 were returned.

One-half of the pretest subjects were debriefed by telephone after the questionnaires had been returned. They were asked about the claricy of questions, the levigth of the questionnaire, their opinions about how high school students would react to the questionnaire. The pretest and debriefings were positive, and were helpful in surfacing several ambiguities and inconsistencies in the question instructions and format. The instrument was edited following the pretest.

\subsection{DATA ANALYSIS}

Data were entered and screened for integrity. Screening included checks for wild codes, inconsistent data, and extreme cases. The research questions were addressed with descriptive statistics, frequencies, Spearman correlations, and a series of GoodmanKruskal lests of association. The Goodman-Kruskal $\lambda$ as a measure of association was appropriate for this study because it is an asymmetric test (dependent and independent variables can be treated as distinguishable) and it requires only categorical data. Lambda 
values fall between 0 and 1 , and represent the expected reduction of error in predicting a variable when information about another variable is given. The more elesely variables arc associrted, the more closely does $\lambda$ approximate 1. A drawback of the $\lambda$ statistic is that the hypothesis $\lambda=0$ cannot be tested. This peculiarity was circumvented by testing against a value very close to zero (i.e., .001) for unit-normalized $\lambda$ values; this valuc was considered to be sufficiently close to zero that it could be treated as equivalent lior practical purposes.

Research questions were answered as follows. Income levels. saving and horrowing behaviour (Question 7), and information sources for saving and borrowing (Oucstion 1) were described with frequencies, descriptive statistics, and Sptarman correlation coefficients. The independent variable effects (Questions 2 to 6) werc analyzed hy running cross classification tables and computing Goodman-Kruskal lambda and Spcarman correlation values for indicators of income, saving and borrowing behaviour, and information sources for each independent variable.

Analysis of cluster design effects was not possible. In order to guarantee the anonymity and confidentiality of respondents, the Carleton University Ethics Commiltec required the question which measured the cluster units (classes) to which respondents belonged be removed from the instrument. individual clusters were therefore not identifiable. 


\section{CHAPTER 6: FINDINGS}

An overall response rate of 43 percent yielded 371 returned questionnaires from the 8 participating schools. Respondents ranged from 13 to 22 years of age, with 75 percent falling in the age group 15 to 19; the mean age was 17 . Grades 10 through 13 were each well represented, with a skew towards the higher two grades. Approximately 54 percent of the sample was female, and 46 percent male. Age, grade, and gender distributions are discussed further in the relevant sections below.

The 8 subsections in this chapter address the research questions presented in Chapter 2. A gencral description of ircome, and borrowing and saving behaviour in the first two sections set the stage for an analysis of the effects of the independent 1 -riables (information sources, materialism, consumption orientation, socio-economic status, age, and gender) in the subsequent 6 subsections.

\subsection{Income}

Income was measured by asking respondents to report their incomes and sources of income for the previous 6 month and 1 month periocis. The 6 month period included the 1992 summer months (July and August), when it was expected that some respondents would have had beld full-time jobs. Since the data were collected in November 1992, the previous month's income was incone received durii:s a typical school month. 
A summary of respondent incomes is presented in Tables 3 and 4 . The distributions followed a positively skewed hyperbolic curve, with averages of $\$ 1846$ (median $=\$ 12(x))$ for the previous 6 months, and approximately $1 / 6$ of that $($ mean $=\$ 250$, median $=\$ 2(x))$ for the preceding inonth. Sources of income varied among respondents, and between time frames. Most received a large percentage of their income from onc or two sources: indeed, $94 \%$ of respondents received more than $50 \%$ of their previous month 's income from a single scurc:. In the 6 month time frame, $80 \%$ of respondents received more than one half of their liscome trom a single source.

Approximately $26 \%$ received income during the previous 6 months from full-lime summer jobs, 34\% from part-time summer jobs, $65 \%$ from part-lime jobs during the schexi year. $30 \%$ from babysitting, $46 \%$ from allowance, $41 \%$ from gifis of moncy, and $18 \%$ from other sources. These other sources most notably included parents, odd jobs, and sikcial assistance; but also occasionally reported as sources of income were "husiness". return on investment, theft, and drug money. During the previous month $57 \%$ of respondents reported income from part-time jobs, $19 \%$ from babysitting, $40 \%$ from allowance, $15 \%$ from gifts of money, and $14 \%$ from other sources. Approximately 10 percent of respondents reported no earned income during the previous 6 months, and 28 frircent no earned income during the previous month.

As a group respondents received most of their income during the preceding 6 months from summer jobs (33\% of total income), part-time jobs during school (28\% of total 

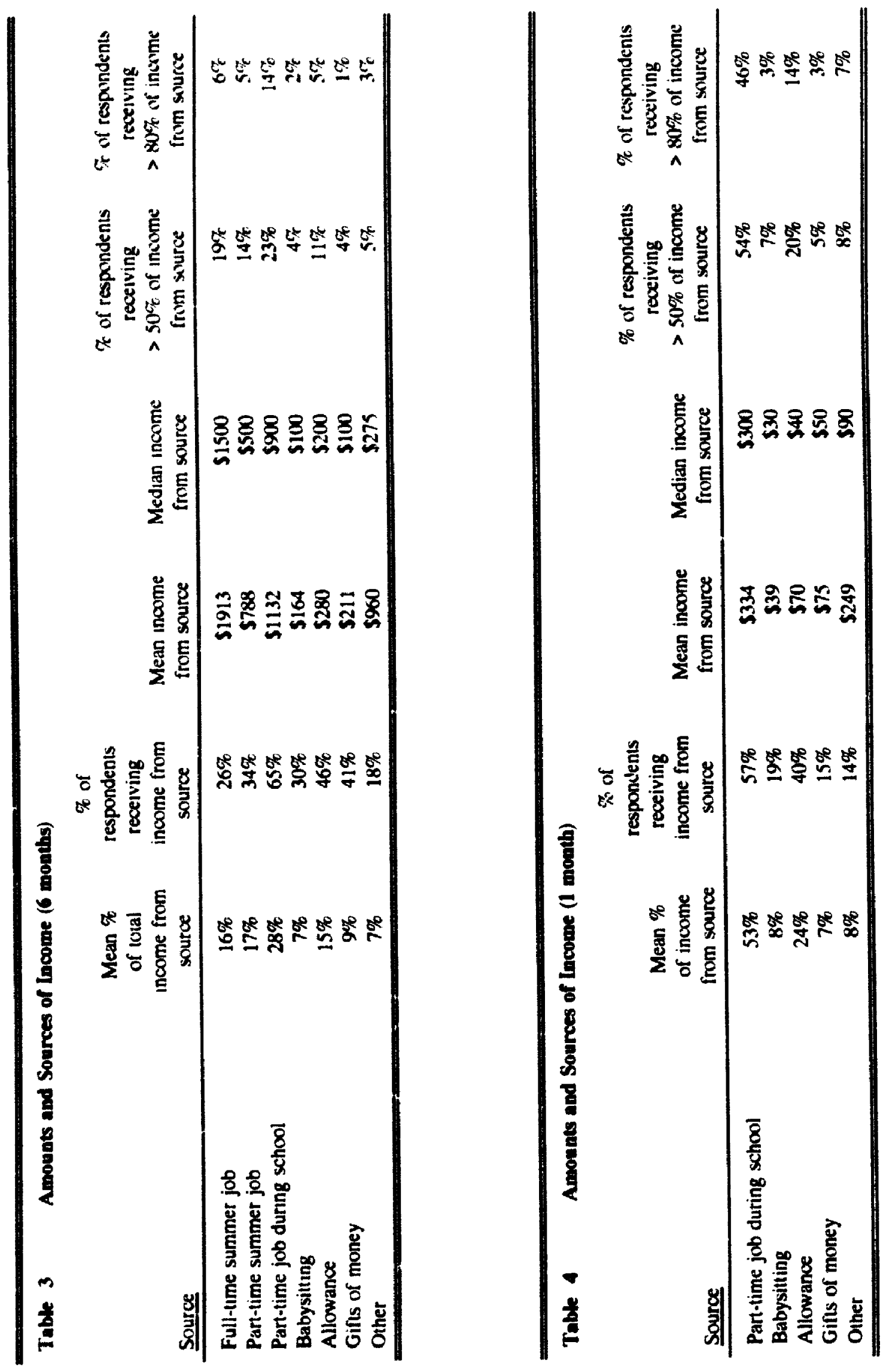
income), and allowance (15\% of total income). During the schoul year the most significant sources of income were part-time jobs $\left(53^{\circ}\right.$ of total monthly income) and allowance ( $24 \%$ of total monthly income).

Respondents listed items that they purchased in the previcis 6 months that totalled an average of $\$ 800$ (median $=\$ 430)$. Values ranged between $\$()$ and $\$ 16,4(x)$, with a coefficient of skewness of 6.124. It was interesting to note that respondents on averagre spent an average of $382 \%$ more moncy (median $=230 \%$ ) than they reported as income in the previous 6 months. Total purchases were included as a dependent variable in the study, and are further discussed in the following sections of this chapter, and in Chapter 7.

\subsection{Saving and Borrowing}

In order to address the independent variable effects on borrowing and saving behaviour, the question of describing this behaviour must first be addressed:

Q: How can adolescent saving and borrowing be described?

Borrowing and saving are described here in terms of the extent of, methods of, and reasons for this behaviour. 


\section{Extent and Methods of Saving.}

Saving behaviour was found to be quite prevalent among respondents. The extent and method of their saving behaviour was measured by asking how much money they had saved currently in a variety of different ways. Responses to these questions are summarized in Table 5. The mean savings balance of respondents was \$2415 (median $=\$ 1100)$. As with income, the frequency distribution of total savings was highly skewed (coefficient of skewness $=1.48$ ), with most respondents falling at the lower end. Indeed, $15 \%$ had savings of kess than $\$ 100$.

The most common method of saving was by far personal savings accounts: apf roximately $81 \%$ of those questioned had a savings account. Bonds and personal chequing accounts were the two next most prevalent mechanisms of saving, with $20 \%$ of respondents using chequing accounts and $38 \%$ of respondents owning bonds. Other methods of saving included term deposits (owned by $13 \%$ of respondents), other bank accounts (.2\%), mutual funds or other investments $(9 \%)$, a parent's bank account $(8 \%)$, and "other" (12\%). The most notable other method of saving was a home depository of some sort; it was declared by $7 \%$ of respondents.

More sophisticam savings methods, such as bonds, mutual funds and term deposits, were correlated to the magnitude of savings balances. Positive Spearman correlation coefficients between total savings and the balance of funds saved in term deposits, bonds, arid mutual funds were $.33, .41$, and .28 respectively (significant at the .01 level). For 
those who saved in these ways the average amounts saved were: $\$ 3086$ (median $=\$ 2(K)$ ) in term deposits, $\$ 2193$ (median $=\$ 1000)$ in bonds, and $\$ 3518($ median $=\$ 13.50)$ in mutual funds. Average amounts saved in bank accounts were: $\$ 817$ (median $=\$ .3(x)$ ) in personal savings accounts, $\$ 722$ (modian $=\$ 292$ ) in chequing accounts, and $\$ 788$ (median $=\$ 450)$ in other accounts.

Personal savings accounts held the highest proportion of total savings for most respondents . Approximately $42 \%$ of respondents kept over half of their savings, in their own savings account. Only $21 \%$ of those with bonds kept over half of their money there. and less than $10 \%$ of respondents had over half of their money saved via any other single mechanism.

When asked the extent to which they regularly put aside a portion of their income fior savings, almost $25 \%$ of respondents replied that they "always" did. Approximately 6()$\%$ fell between "sometimes" and "never." Those that did claim to save regularly were slightly more likely to have a higher level of savings (Spearman $r=.16, P_{1}=.(00)$, hut not significantly more likely to save via any particular saving mechanism.

Approximately $27 \%$ of respondents had spent all of their income from the previous month. Around $44 \%$ had more than half of their money remaining, and $13 \%$ had more than $80 \%$ remaining. Those that said they saved regularly were likely to have more of 
their previous month's income than were those who said they did not save regularly $\left(r=.41, P_{z}=.(0)\right)$

\section{Reasons for Saving.}

When asked if they saved money for specific things, approximately $32 \%$ of respondents reported that they sometimes did; $21 \%$ reported that they almost always did; and $33 \%$ reported that they always did. Only $14 \%$ of respondents said that they never or almost never saved for specific things. Reasons for which respondents saved were measured by asking them if they were saving for a variety of thing that the literature indicated adolescent often save for. If they were saving for these reasons, the amouats that they currently had saved for each reason was asked. Responses are summarized in Table 6.

The most common reason for saving was future education, with $34 \%$ of respondent saving for that purpose. Other reasons included travel (25\% of respondents), clothing (17\%), "a rainy day" (14\%), and a car or car-related expenses (14\%). About $25 \%$ of respondents were saving for "other" reasons, most notably Christmas gifts, hobbies, or sports equipment. On average, the most money had been saved for future education $($ mean $=\$ 2661$, median $=\$ 1700) ;$ next came a car and car expenses $($ mean $=\$ 2099$, median $=\$ 1000)$, and travel $($ mean $=\$ 768$, median $=\$ 300)$.

The amounts which respondents listed they were saving for specific things were in excess of half of their total savings for over $63 \%$ of respondents. Some respondents had a large 

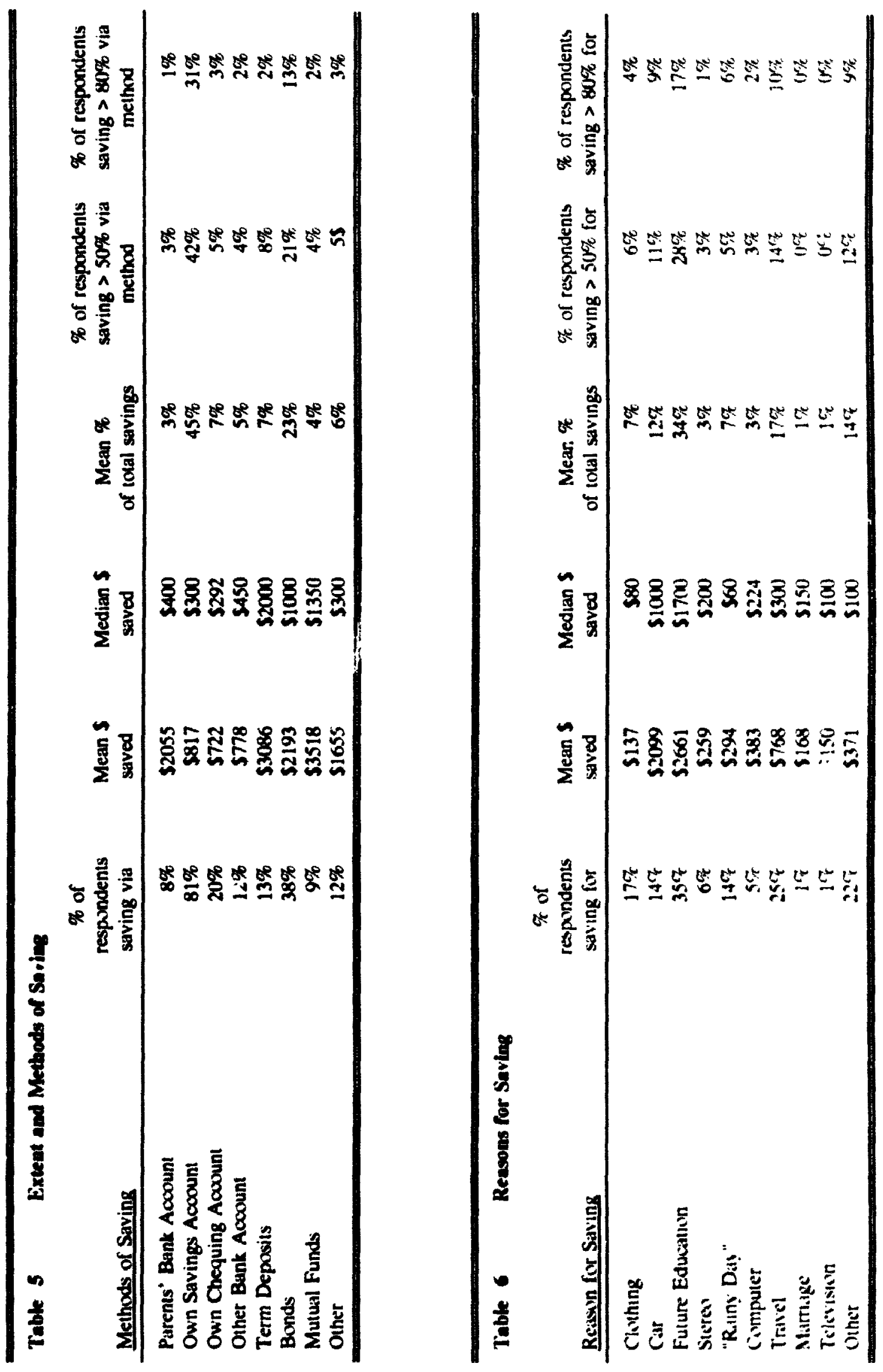
percentage of their savings dedicated to one specific thing. The reasons for which respondents had dedicated the largest portion of their savings were future education and travel: $38 \%$ of thosc saving for future education had dedicated over half of their savings to that causc. Similarly, $14 \%$ of those who were saving for travel had dedicated over half of their savings to that cause.

\section{Extent and Methods of Borrowing.}

Borrowing behaviour was measured similarly to saving behaviour. Respondents were asked if they had used specific sources of debt before, and if so, what the current outstanding balances were. Responses are summarized in Table 7.

The majority of respondents had no current debts (58\%). Approximately $26 \%$ had debts less than $\$ 100$, and only $16 \%$ owed more than $\$ 100$. The frequency distribution for total debt was highly skewed (coefficient of skewness $=7.2$ ), with outstanding debts ranging up to about $\mathbf{\$ 5 0 0 0}$. Of those with debts the mean balance was $\$ 515$ (median $=\$ 50$ ).

Borrowing was quite common, however. Approximately $67 \%$ of respontents had borrowed from friends in the past, and $69 \%$ from parents. Less than iain of these borrowers had outstanding debts from those sources, even though over $40 \%$ of them had borrowed during the previous month. Approximately 33\% of respondents owed money to friends, with an average balance of $\$ 54$ (median $=\$ 20$ ); $28 \%$ cf respondents owed moncy to their parents, with an average balance of $\$ 481$ (median $=\$ 97$ ); and $5 \%$ of 
respondents owed money to "other" sources (mainly siblings and relatives), with an average of $\$ 754($ median $=\$ \$ 50)$.

When asked if they had borrowed moncy via credit cards, $77 \%$ of the sample reported that they had not. Roughly $10 \%$ reported using their parents' major credit eards, $7 \%$. their parents' department store cards, and 4\% their parents' gas cards. Only 1 is $2 \%$ of people claimed to have any debt outstanding from these credit purchases. Few respondents had their own credit cards: $3 \%$ had department store cards, $2 \%$ had their own major credit cards, and $1 \%$ their own gas cards. Amounts of total outstanding debt were highly correlated $\left(r=.42, P_{r}=.00\right)$ with the amount that respondents borrowed from their parents.

Further insight into the use of credit cards was sought by asking questions about the frequency of use, payment practices, and other aspects of credit card use. The questions were asked only of those who had used credit cards before. Responses are summarized in Table 8. Respondents indicated that they used both their own and their parents' credit cards relatively infrequently. Most paid their entire bills every month, and used their own money to do so. Most respondents said that they usually would not use a credit card unless they had money to pay the bill. It was also evident that a substantial portion of those who used their parents ${ }^{\prime}$ credit cards did not pay them back for the moncy they spent. 
Reasons for Borrowing.

Table 9 summarizes the reasons for which adolescents borrow money. Clothing was the single-most prominent itcm of debt spending: $14 \%$ of respondents reported purchasing clothing with a credit card, and $19 \%$ with borrowed money, during the previous 6 months. These debl-funded purchases comprisud a sizable portion of total purchases: an average of $9 \%$ of total clothing purchases were made on credit, and $8 \%$ with borrowed money. The average expenditure for those respondents who bought clothing during the previous 6 months was $\$ 370$ (median $=\$ 200)$.

Sports equipment was the next-most significant category on which purchases were financed with debl. Approximately $4 \%$ of respondents reported purchasing sports equipment with credit cards, and $6 \%$ with borrowed money, during the previous 6 months; an average of $4 \%$ of sports equipment purchases wcre made with credit cards, and $5 \%$ with borrowed money. The average expenditure for those respondents who bought sports equipment during the previous 6 months was $\$ 185$ (median $=\$ 100)$.

Audio recordings (records, CDs, tapes) were a commonly purchased item, but relatively fewer people financed their purchases with debL Approximately $3 \%$ of respondents made audio recording purchases with credit cards, and $4 \%$ with borrowed money; an average of $2 \%$ of audio recording purchases were made with each of credit cards and borrowed money. The average expenditure for those respondents who bought audio recordings during the previous 6 months was $\$ 110$ (median $=\$ 50$ ). 


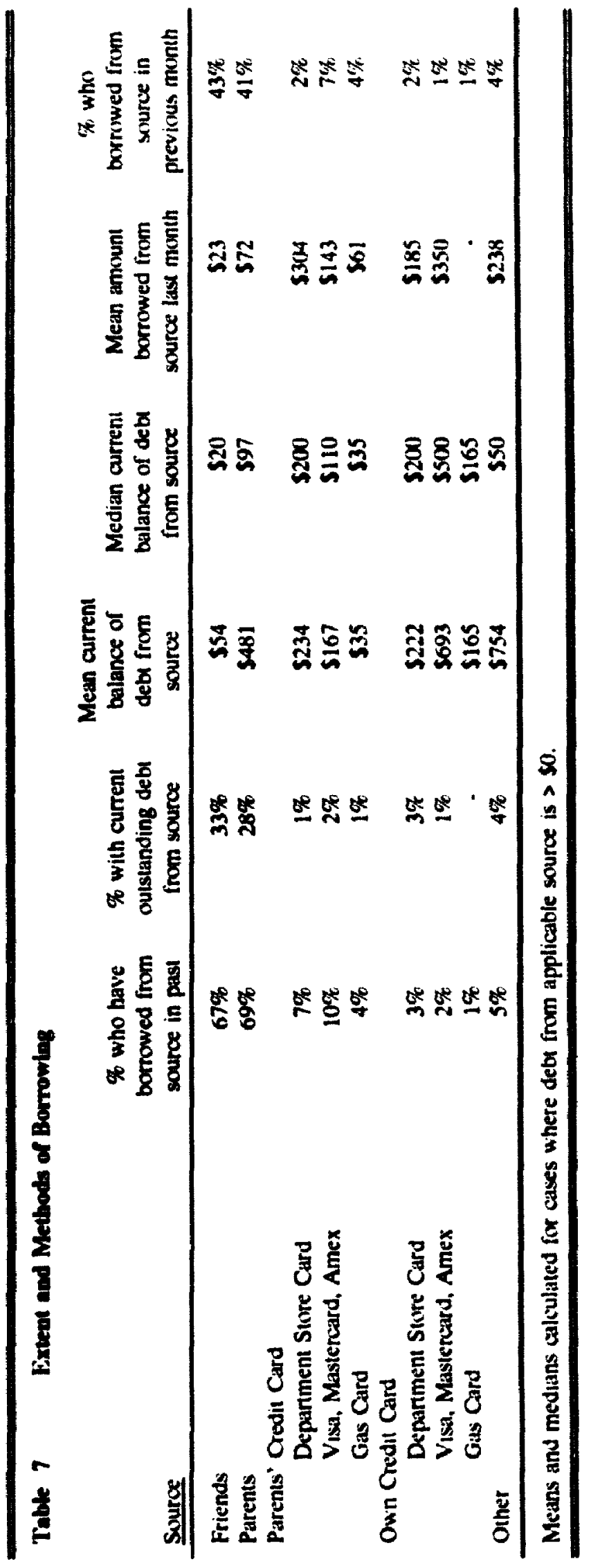




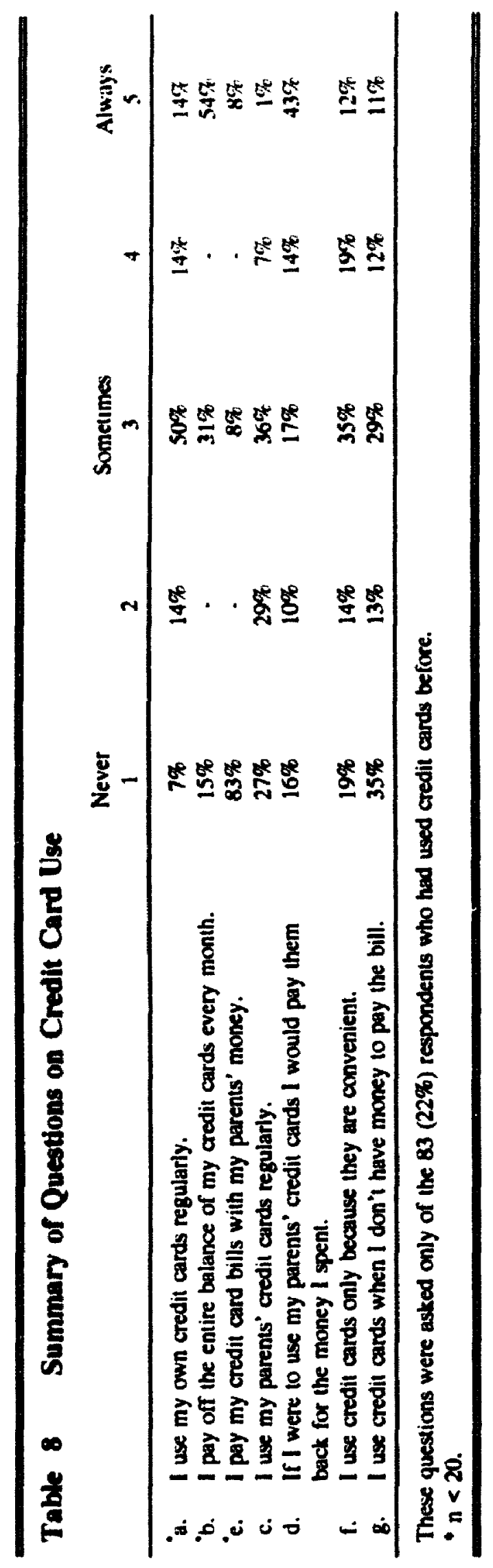




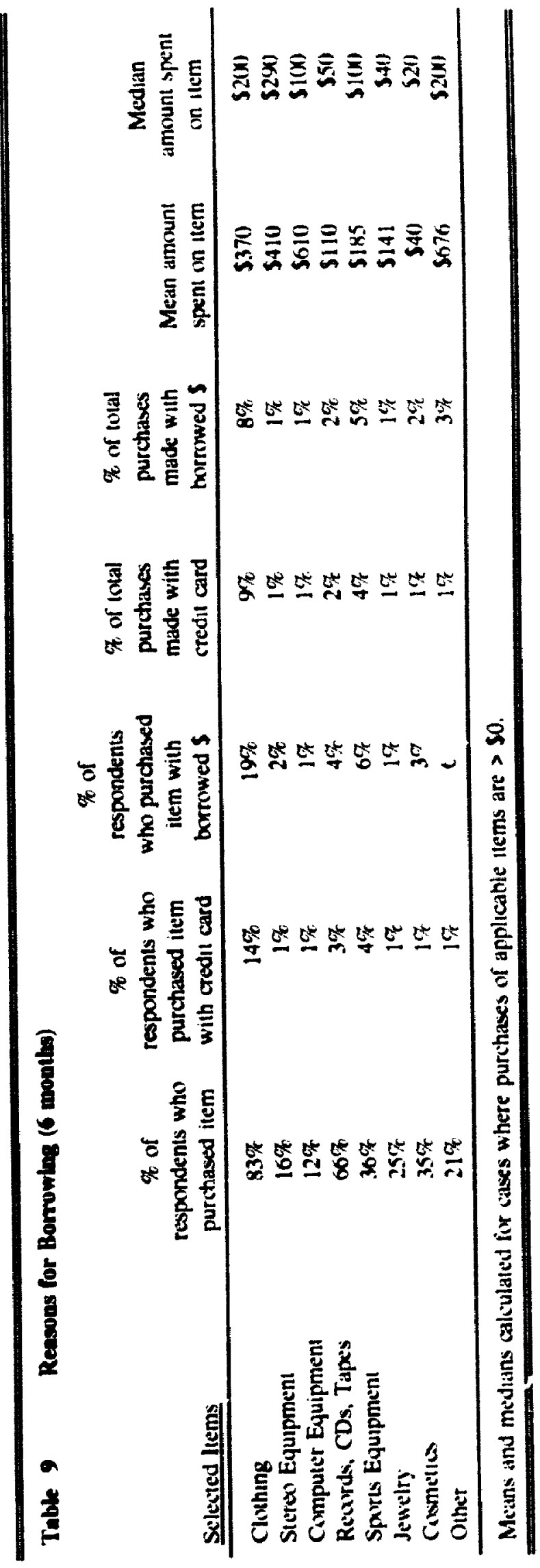


Stereo equipment, corıputer equipment, jewelry, cosmetics, and "nther" purchases were all made by fewer reople, with 1 to $2 \%$ of respondents purchasing each of them with crudit cards or ixorrowed moncy. Approximately 1 to $2 \%$ of total purchases of those itcms werc made on credit or with borrowed moncy. Average amounts spent on these Items were $\$ 410($ median $=\$ 290)$ for stereo equipment, $\$ 610($ median $=\$ 100)$ for computer equipment, $\$ 141$ (median $=\$ 40)$ for jewelry, $\$ 40($ median $=\$ 20)$ for cosmetics, and $\$ 676($ median $=\$ 200)$ for $"$ other" purchases.

\subsection{Information Sources}

One of the objectives of this research was to extend past studies of consumer socialization to financial stages of the purchasing process. Since information gathering is a stage in this procuss, and information sources an ir portant variable in past studies of adolescent consurict learning, it was of interest to determine what informatiou sources adolescents use in the saving and borrowing context:

Q: Do any of the following serve as information sources for adolescent saving and borrowing: parents; friends; bank tellers or salespeople; brochures or newspaper and mag." r.s ads; television ads; or books and consumer reports?

Indices representing the extent of information seeking of respondents when saving and borrowing were derived from Moschis' (1978b) index of information seeking, which he used in the purchasing context. Moschis noted the desirability of the measurement 
device. It measured the number of sources an adolescent would expressly consult betore making a purchase decision. Possible value ranges for the index were $1 \cdots 8$; in this study values fell between 1 and 4.43 for the saving index, and between 1 and $o$ fior the borrowing index. Respondents indicated that they would rely on an average of 1.4 (median $=2.0$ ) sources for information belore deciding to save vi:: a particular mechanism, and 1.9 (median $=1.8$ ) before deciding to borrow via a particular debt mechanism (see Table 10). The $\alpha$-reliability coefficients for these indices were . $\$ 6$ lior saving and .91 for borrowing. Moschis (1978b) reported an $\alpha$ of .37 for his index.

The sources from which respondents indicated they would obtain information beforc saving and borrowing are summarized in Table 11 . The sources most often mentioned were parents and bank tellers/salespeople. Approximately $92 \%$ of respondents indicated that they would obtain information or advice from their parents about at least onc of the listed savings mechanisms before saving in that way; $97 \%$ would ask for information or advice from their parents about at least one of the listed debt mechanisms before borrowing in that way. Approximately $73 \%$ would consult bank tellers/salespeople before saving, and $79 \%$ would consult bank tellers/salespeople before borrowing. Television advertisements were the least consulted source of information, with less than $25 \%$ of respondents relying on them for information. Other sources (friends, broks and consumer reports; brochures, newspaper and magazine ads) would be consulted only by 30 to 40 percent of respondents, with the exception of friends in the case of borrowing: 
this anomaly was duc to the fact that $65 \%$ of the sample indicated that they would consult fricnds before using a pawnbroker service.

It was of interest to know whether respondents who said they would use certain sources of information for saving would use the same for borrowing. Each of the information sources for saving was found to be relatively strongly correlated to the corresponding information source for borrowing (see boldface entries in Table 12).

Information that respondents considered important to have before saving or borrowing is summarized in Table 13. Responses indicated that most respondents thought that specific financial information (interest rates, payment terms, service charges) was very important. Most other information, with the exception of information about friends' financial activitics, was indicated as at least moderately desirable. $f$. significantly larger proportion of the sample seemed to have greater information needs when borrowing than when saving. most likely due to the fact that saving was in general a more familiar activity than was borrowing. 


\begin{tabular}{|c|c|c|c|}
\hline \multirow[t]{2}{*}{ Table 10} & \multicolumn{3}{|c|}{$\begin{array}{l}\text { Extent of Information Seeking by Saving and Borrowing } \\
\text { Mechanisms }\end{array}$} \\
\hline & & $\begin{array}{l}\text { Mean number of } \\
\text { Sources Consulted }\end{array}$ & $\begin{array}{l}\text { Median number of } \\
\text { Sources consulted }\end{array}$ \\
\hline \multicolumn{4}{|c|}{ Saving Mechanisms } \\
\hline Parents' B & ak Account & 1.6 & 1 \\
\hline \multicolumn{4}{|c|}{ Respondent Bank Account: } \\
\hline Savings & ccount & 2.0 & 2 \\
\hline Chequin & account & 2.0 & 2 \\
\hline Other $b$ & k account & 2.0 & 2 \\
\hline Term Dep & its (CDs, GICs) & 2.1 & 2 \\
\hline Bonds & & 2.1 & 2 \\
\hline Mutual Fu & is, Stocks, etc. & 2.3 & 2 \\
\hline Other & & 2.1 & 1 \\
\hline \multicolumn{4}{|c|}{ Borrowing Mechanisms } \\
\hline \multicolumn{4}{|c|}{ Respondent Credit Cards } \\
\hline Departm & nt Store & 2.3 & 2 \\
\hline Visa, $\mathbf{M}$ & stercard, Amex & 2.4 & 2 \\
\hline Gas Sta & & 2.1 & 2 \\
\hline \multicolumn{4}{|c|}{ Parents' Credit Cards } \\
\hline Departm & nt Store & 1.8 & 1 \\
\hline Visa, $\mathbf{M}$ & tercard, Amex & 1.9 & 2 \\
\hline Gas Sta & & 1.8 & 1 \\
\hline Other Cred & Cards & 2.2 & 2 \\
\hline Bank Loan & & 2.3 & 2 \\
\hline Pawn Brok & & 1.8 & 2 \\
\hline Friends & & 1.5 & 1 \\
\hline Parents & & 1.4 & 1 \\
\hline Other & & 1.9 & i \\
\hline
\end{tabular}




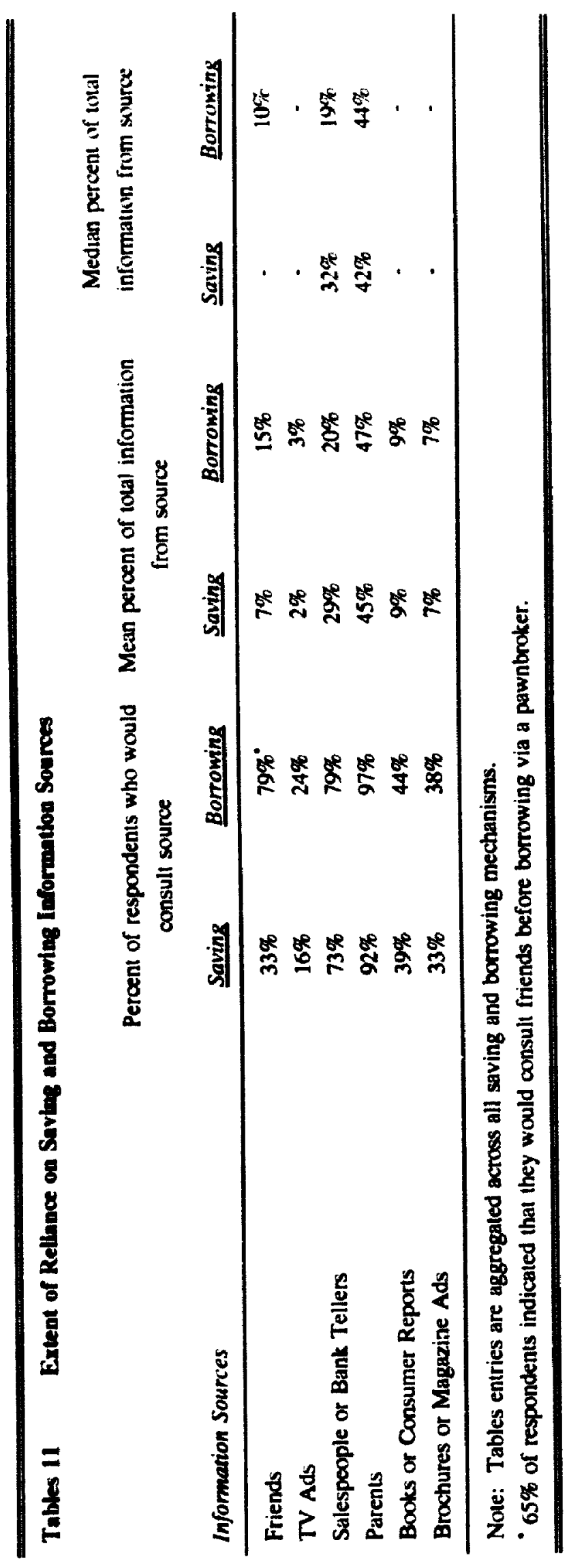




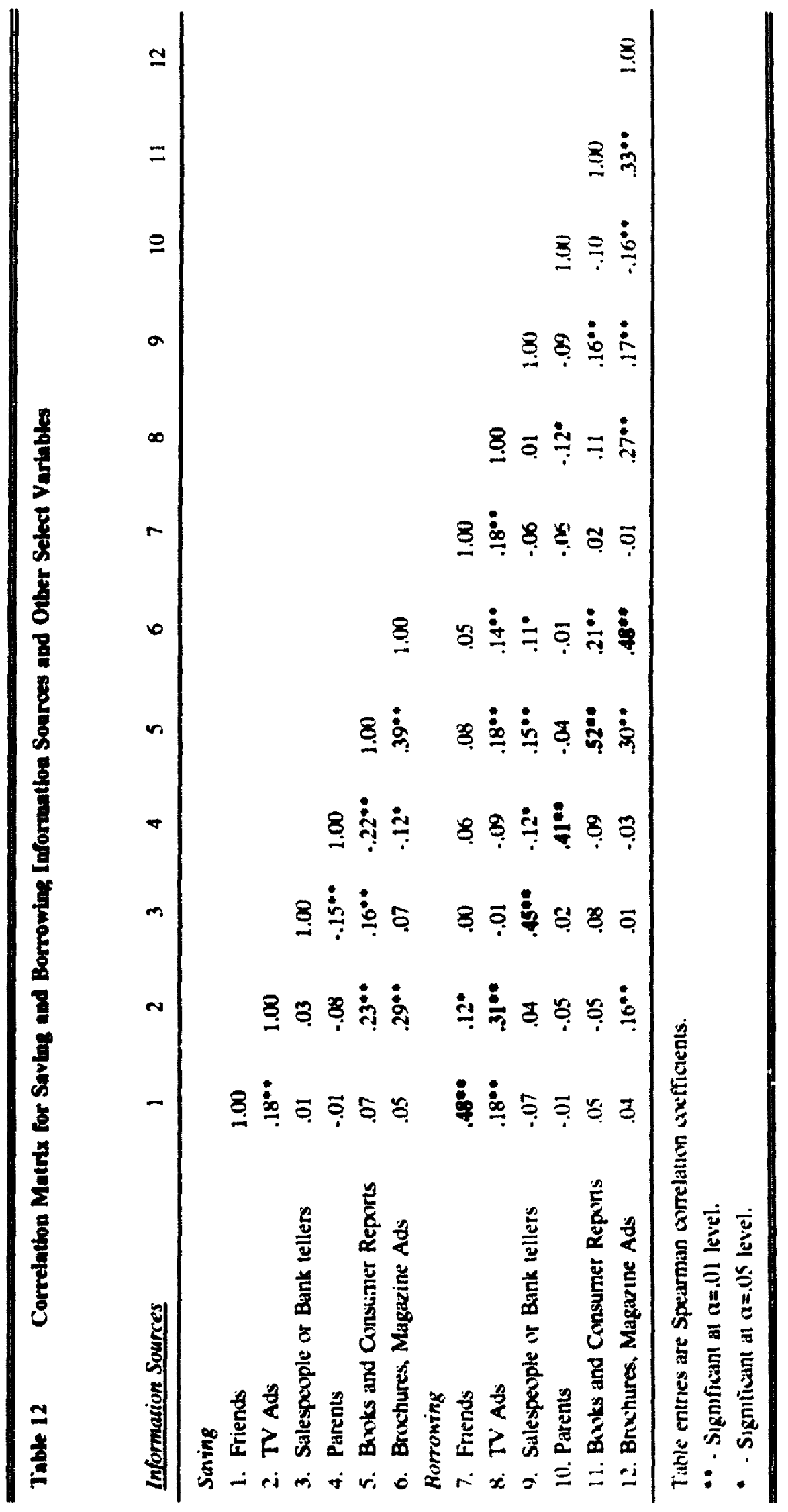




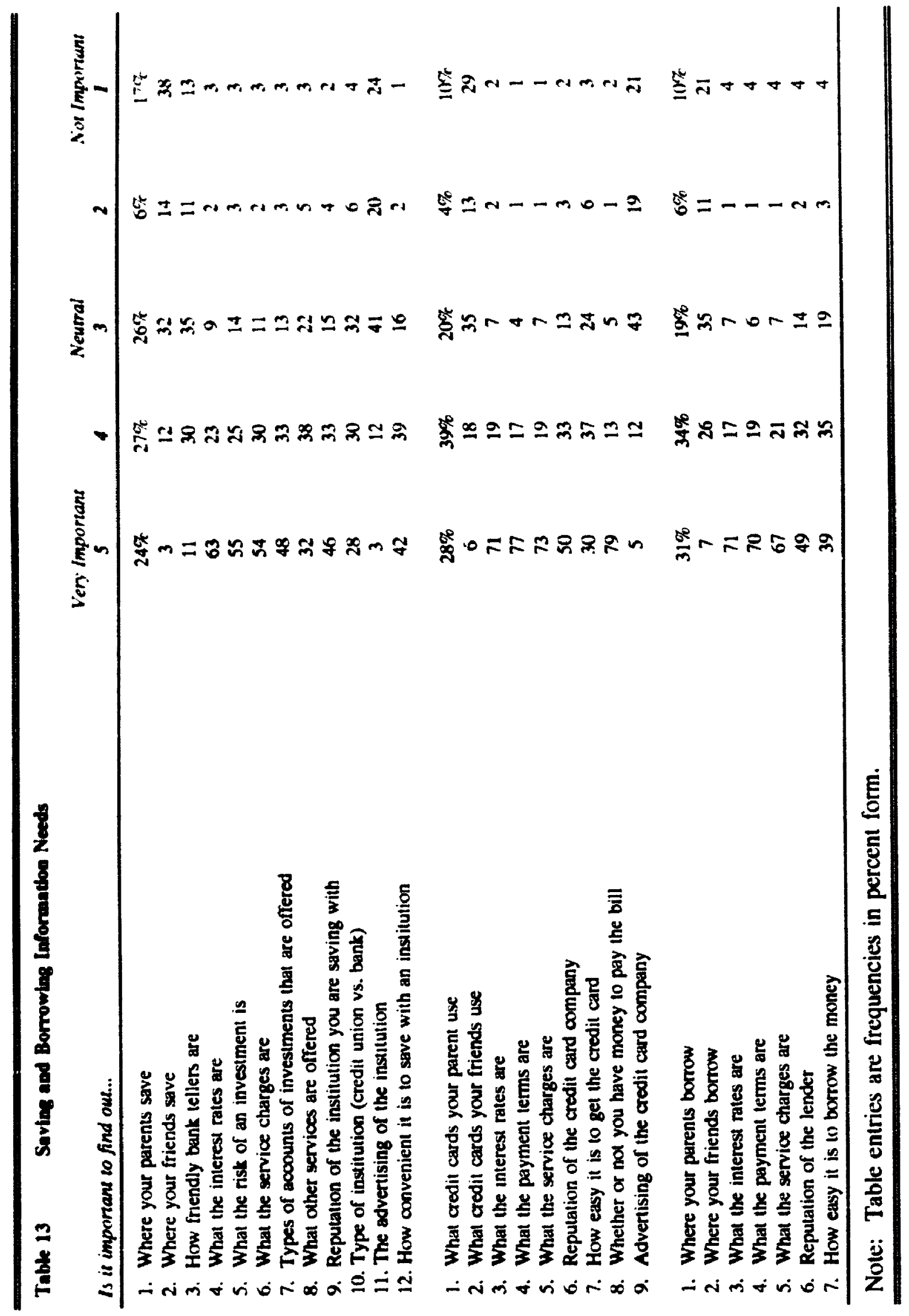




\subsection{Socio-Economic Status}

Family socio-economic status was an important variable in past consumer socialıation studies. Its effect on the financial behaviour of adolescent was therefire of interest:

Q: Are there socio-economic differences in adoliscent saving and borrowing behaviour or information seeking?

Socio-economic status was measured in terms of the education, occupation, and income of respondents' parents, as described in Section 5.1.4.1. Values for the index used in measure socio-cconomic status ranged from 1.3 to 9.0, with a mean of 5.6, (median $=5.6$ ), variance of 2.7 , and coefficient of skewness of -1.164 .

Associations between socio-economic status and select dependent variables are summarized in Table 14. A strong negative association was found between sxcioeconomic status and total income $(\lambda=.156, \alpha=.01)$, and a somewhat weaker négative association with total debt $(\lambda=.063, \alpha=.05)$. Those of higher socio-ecomomic status were more likely to have higher personal savings account balances $(\lambda=.159$, $(2=.(1)$, were more likely to save regularly $(\lambda=.097, \alpha=.01)$, and were less likely to save their moncy for specific things $(\lambda=.176, \alpha=.01)$, and were more likely to have spent more moncy during the previous 6 months $(\lambda=.121, \alpha=.01)$. Furthermore, those of higher socineconomic status were much more likely to use their parents' credit cards frequently $(\lambda=.375,(\ell=.1) 1)$, and not repay their parents' for the purchases made on their credit cards $(i=.4(x),(\ell=.(1))$. 


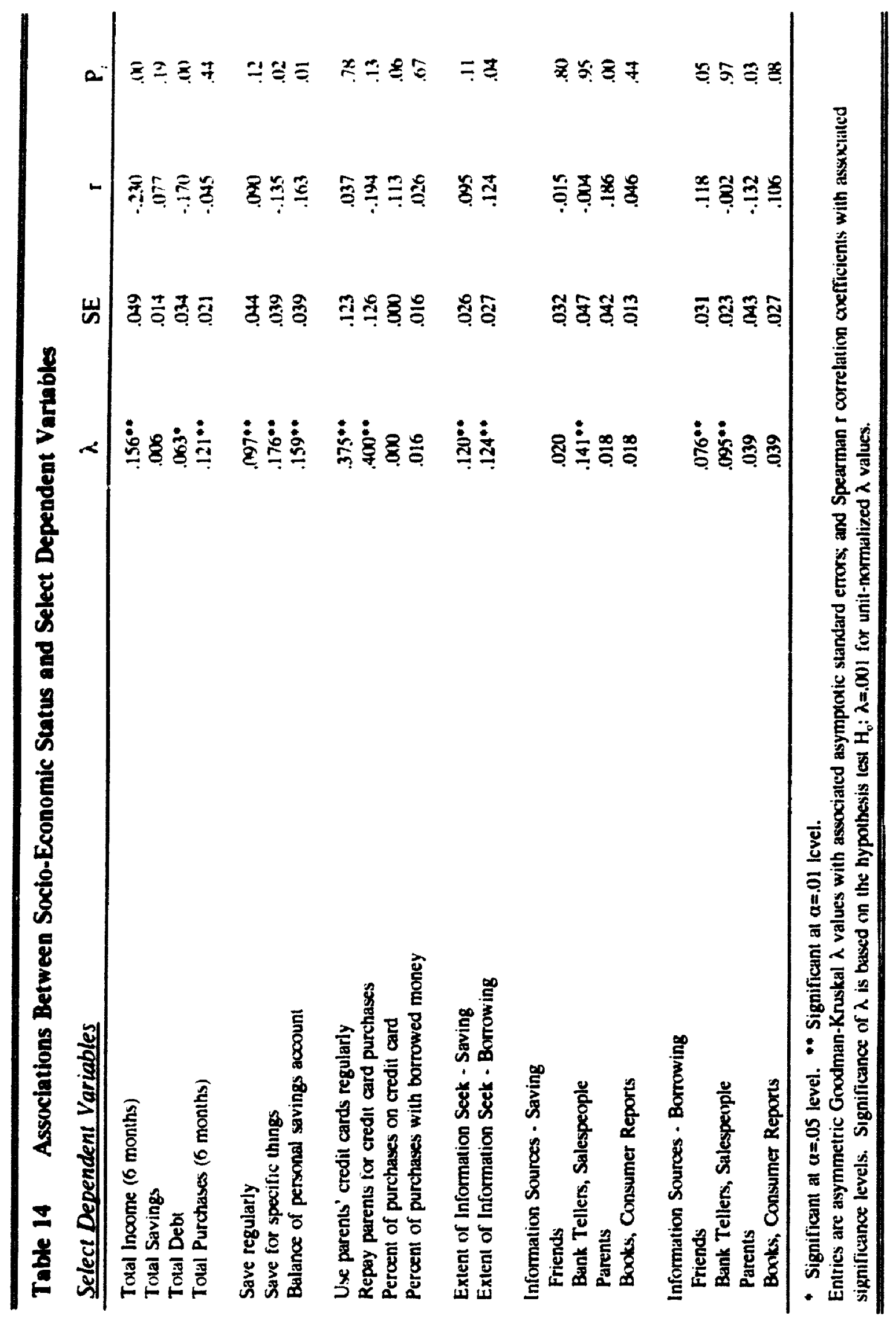


Respondents of higher socio-economic status were found to consult more sources lor infirmation about saving $(\lambda=.120, \alpha=.01)$ and borrowing $(\lambda=.124, \alpha=.01)$. The use of particular information sources was predictable from the socio-economic status of respondents. Friends were ciled more often as a source of information for borrowing $(\lambda=.(176,(\alpha=01)$ for those of higher skcioeconomic status, with pawnshops being the specific debt mechanism fir which this informiation was sought. Associations were also found between sccio-economic status and reliance on hank tellers/salespeople as a source of information for saving $(\lambda=.141, \alpha=.(1)$ and horrowing $(\lambda=.095, \alpha=.01)$. These latter two relationships were bimodal: thesse with very high or very low socio-economic status could rely either a lot or a litte, but not moxderattely, on bank tellers/salespeople.

\subsection{Age}

Age is used in consumer socialization studies as a measure of cognitive development, ano : expected to be related to financial activity of youngsters. The following rescarch questusns was therefore asked:

Q: Are there age differences in adolescent saving and borrowing bchaviour or information seeking?

The ages of respondents (see Table 15) ranged from 13 to 22, with a mean age of 16.8 (median $=17$, variance of 2.0 , and coefficient of skewness of 0.437 . Approximately $95 \%$, of respondents were between the ages of 15 and 18 . 


\begin{tabular}{|c|c|c|}
\hline Table 15 & Age Distribution & \\
\hline Age & Frequency & Percent \\
\hline 13 & 1 & $.5 \%$ \\
\hline 14 & 4 & $1 \%$ \\
\hline 15 & 69 & $19 \%$ \\
\hline 16 & 76 & $21 \%$ \\
\hline 17 & 96 & $27 \%$ \\
\hline 18 & 80 & $22 \%$ \\
\hline 19 & 16 & $5 \%$ \\
\hline 20 & 12 & $3 \%$ \\
\hline 21 & 3 & $1 \%$ \\
\hline 22 & 1 & $.5 \%$ \\
\hline Totnl & 358 & $100 \%$ \\
\hline
\end{tabular}

Table 16 summarizess associations between select dependent variables and age. Although age was expected to be an imponant predictor variable in this study, only one significant association was lound: age was associated with the balance of savings in personal savings accounts $a=.122, \alpha=.05)$. Older respondents tended to have either a very low or a very high balance in their savings accounts, while the savings account balances of younger respondents tended to be more uniformly distributed. 


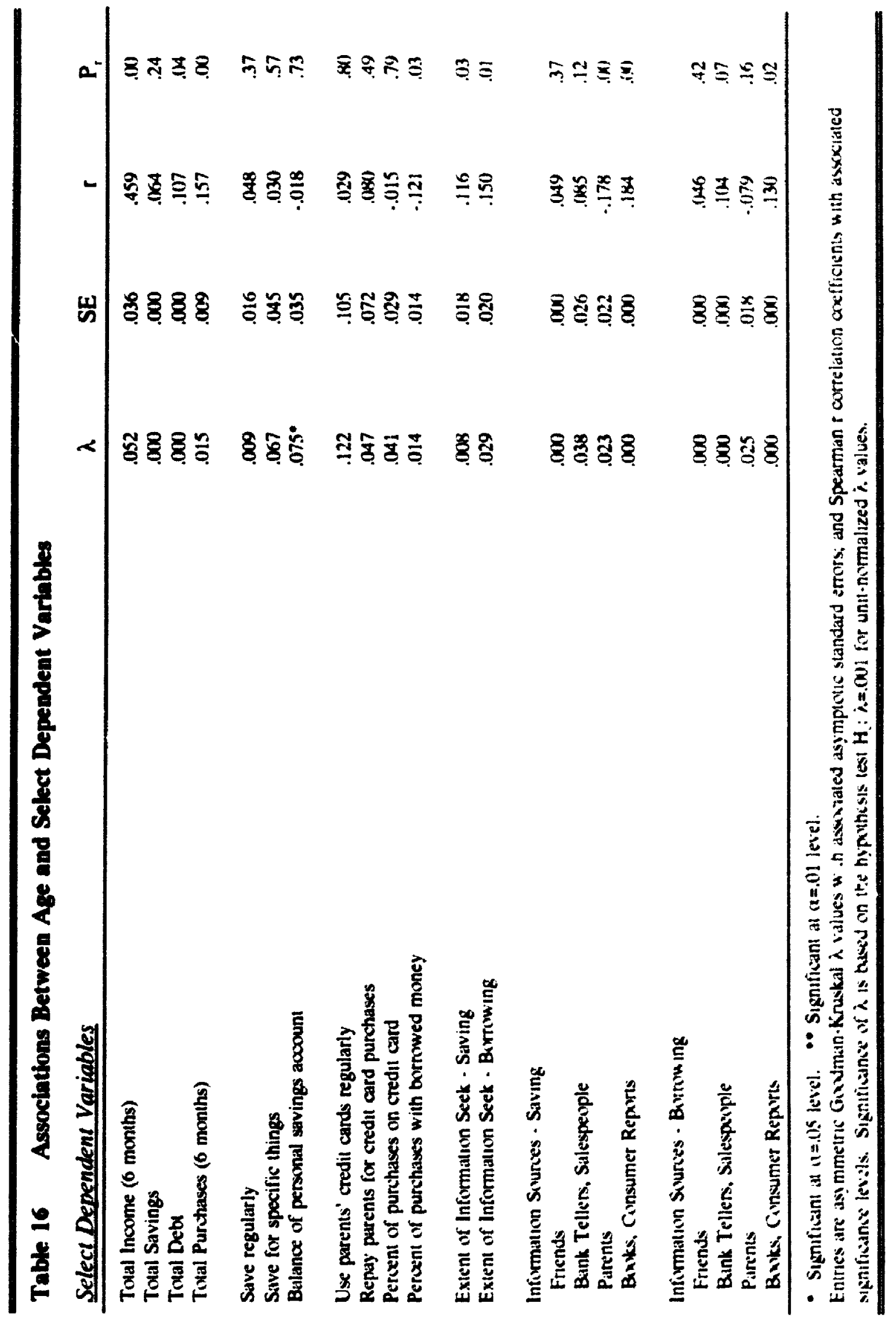


Age was used as a measure of cognitive development, as suggested by Moschis (1978b). Since grade could also be a measure of this same construct, it too was investigated. The 10th through 13th grades were each well represented, with a slight skew towards the higher two grades (see Table 17).

\begin{tabular}{ccc}
\hline $\begin{array}{c}\text { Table } 17 \\
\text { Grade }\end{array}$ & $\begin{array}{c}\text { Grade Distribution } \\
\text { Frequency }\end{array}$ & Perrent \\
\hline 9 & 2 & $.6 \%$ \\
10 & 76 & $22 \%$ \\
11 & 65 & $18 \%$ \\
12 & 119 & $33 \%$ \\
13 & 97 & $27 \%$ \\
Total & 359 & $100 \%$ \\
\hline
\end{tabular}

Lambda values that were found between grade and other variables were all smaller and less significant than those that were found for age. 


\subsection{Gender}

Since gender was used in past consumer socialization studies the following research yuestion wis asked:

Q: Are there gender differences in adolescent saving and borrowing bchaviour or infoumalwill secking?

Approximately $54 \%$ of the sample was female, and the remaining $46 \%$ male. This propurtion of genders was not consistent, however, for the 8 schools which participated in the study (sece Table 18). The proportion of females in the sample ranged from $76 \%$ to $43 \%$, and the propmtion of males ranged from $57 \%$ to $24 \%$. Possible gender selection bias was controlled in the analysis by examining respondents from each school individually.

\begin{tabular}{ccc}
\hline Table 18 & \multicolumn{2}{c}{ Gender Distribution by School } \\
School & Female & \multicolumn{1}{c}{ Mule } \\
\hline 1 & $20(69 \%)$ & $9(31 \%)$ \\
2 & $19(76 \%)$ & $6(24 \%)$ \\
3 & $30(43 \%)$ & $40(57 \%)$ \\
4 & $18(47 \%)$ & $20(53 \%)$ \\
5 & $22(49 \%)$ & $23(51 \%)$ \\
6 & $33(43 \%)$ & $43(57 \%)$ \\
7 & $13(68 \%)$ & $6(32 \%)$ \\
8 & $39(68 \%)$ & $18(32 \%)$ \\
Total & $194(54 \%)$ & $165(46 \%)$ \\
\hline
\end{tabular}




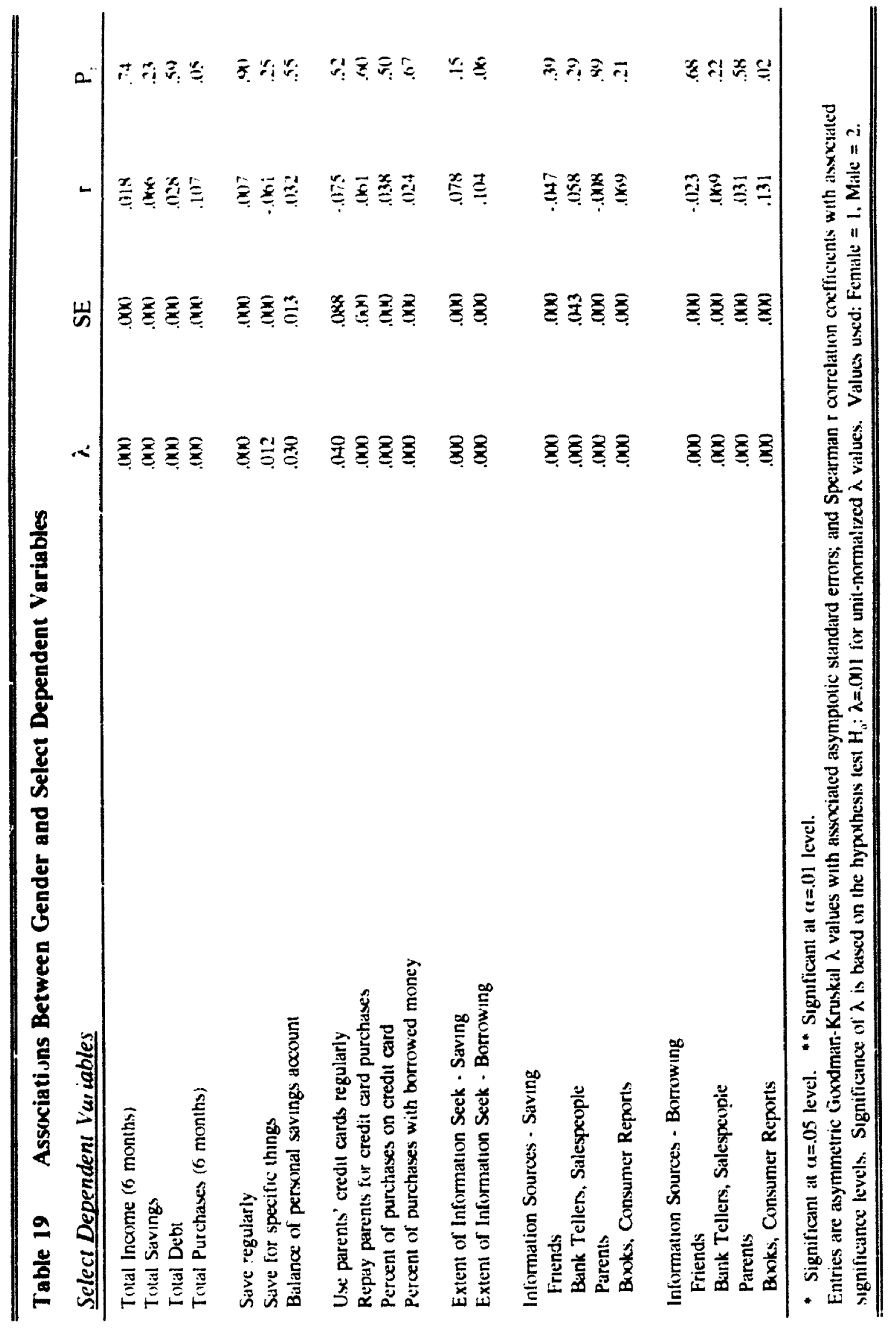


Lambda values of select dependent variables with gender are presented in Tahle 10. No significant associations were found between gender and the dependent vartable's neille't for the sample as a whole, nor for any individual school. All $\lambda$ values were cluse w ハro and were highly insignificant. This was somewhat surprising given that many patst situlus reported that females earned slightly less than makes (Moschis, 1978h; Reuhens, 1983; Statistics Canada, 1989a, 1989c), and that Moschis (1978b) found that liomals's sought more information prior to making purchases (Moschis 19786). A recent study indicated that credit card use was higher among females (Hauser. 1986), hut the study cited datit from an older respondent group (i.e., university students). The lindings of the present study did, however, corroborate Bachman's (1983) lindings of no gender dillerences in the amounts that adolescents save.

\subsection{Materialism}

Materialism was an important variable in past studies of consumer soctialization: therefore, the following question was asked:

Q: How do materialist values affect adolescent borrowing and saving behaviour and information seeking?

Materialism was measured as described in Section 5.1.4.1. The index of materaalism was roughly uniformly distributed, with values ranging between 7 and 23 , and a mean very close to the midpoint of the scale, of 17.4 (median $=18 .(1)$. The scale had a varlance (of 
15.9 and a cerfficient of skewness of -.10. The $\alpha$-reliability coefficient was .56 for this index. Moschis reported a mean of 17.3 and reliability of $\alpha=.60$ in his $1978(b)$ study. Respondents belonging to families of higher socio-economic status were more likely to be more materialist $(\lambda=.181, \alpha=.01)$. No relationships were found, however, between materialism and age or gender.

A summary of the associations of materialism with select dependent variables is presented in Table 20. Materialism was not associated significantly with total income, with total savings, or total debt. More materialist respondents, however, were more likely to save their money for specific things $(\lambda=.095, \alpha=.05)$, and more likely to have spent more moncy in the previous 6 months $(\lambda=.121, \alpha=.01)$. This paradox is discussed in Chapter 7 .

Materialism was related to the balance in respondents' personal savings accounts $(\lambda=.104,(\alpha=01)$, but the association was bimodal: highly materialist respondents could have either low or high savings account balances, but those with lower materialism scores tended to have more moderate balances in their savings accounts. Materialist respondents used their parents' credit cards $(\lambda=.340, \alpha=.01)$ much more frequently than those who werc less materialist, and they were much kess likely to repay their parents for the purchases made with their credit cards $(\lambda=.200, \alpha=.05)$.

Significant associations were found between materialism and the number of sources consulted before saving $(\lambda=.053, \alpha=.05)$, and before borrowing $(\lambda=.064, \alpha=.01)$; in both 


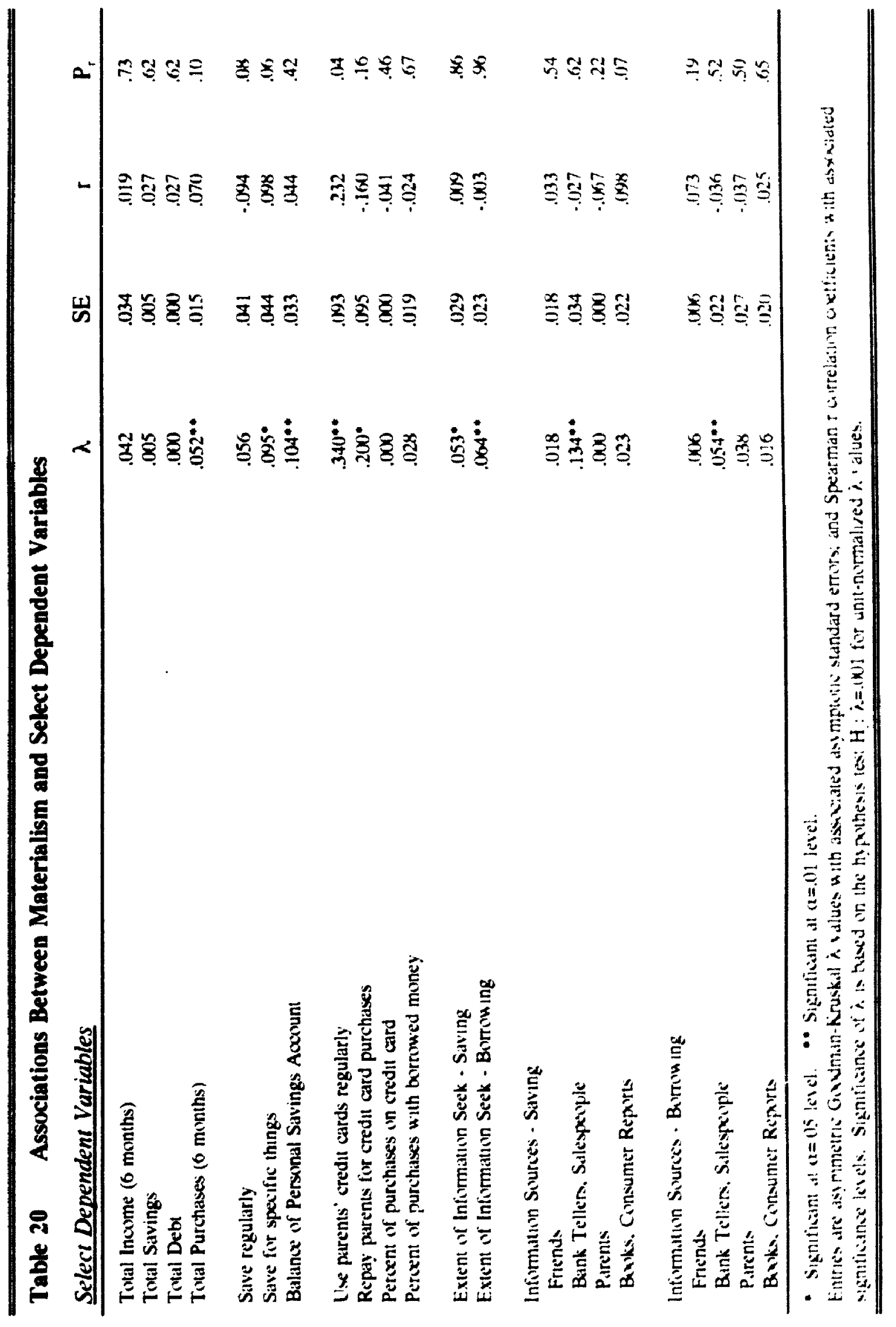


cases respondents who had moderate materialism scores tended to consult more information sources. Although Moschis (1978b) found that materialism was related to a reliance on peers as information sources in the purchasing context, this relationship was not found in the saving and borrowing context. Indeed, bank tellers/salespeople was the only source of information which was related to materialism. The relationships were significant for both saving $(\lambda=.134, \alpha=.01)$ and borrowing $(\lambda=.054, \alpha=.01)$, although markedly stronger for saving. The associations were clearly bimodal: respondents with either high or low materialism scores tended to have either a high or low, but not moderate, reliance on bank tellers as sources of information.

\subsection{Consumption Orientation}

Past studies of consumer socialization used consumption orientation (i.e., social motivations for consumption and cconomic motivations for consumption) in examining adolescent purchasing behaviour. A question aimed at determining the role of consumption orientations in the context of adolescent financial management was therefore asked:

Q: How do consumption motivations affect adolescent borrowing and saving behaviour and information seeking?

Buth social and cconomic motivations for consumption were measured as described in

Section 5.1.4.1. Values for the social motivation scale, which had an $\alpha$-reliability 
coefficient of 83 , ranged between 0 and 20 , with a mean of 3.9 (median $=3 .(1)$, valtiance of 13.3, and a coefficient of skewness of 1.03. Approximalely $25 \%$ of respondents hak a social motivation for consumption score of eero. The economic motivation scale had an $\alpha$-reliability coefficient of .87 , with values ranging from 1 10 25 , a mean of 14.9 (median $=15.0$ ), variance of 30.9 and coefficient of skewness of $-0.16 . \quad \Lambda$ large difference in the means between social and cconomic consumption motivation was also found by Moschis (1978b), who reported a mean of 6.1 for social motivations and 16..3 for economic motivations.

Associations existed among the independent variables. Those with lower soxial motivations were likely to also have low economic motivations $\left(\lambda_{\text {symaxtm }}=.() 6, \alpha=.(1)\right.$ ). Those respondents belonging to families of higher socio-economic status tended to have higher economic motivations for consumption $(\lambda=.146, \alpha=.01)$, and higher sixcial motivations for consumption $(\lambda=.100, \alpha=.01)$. Furthermore, respondents with high sicial motivations were more materialist $(\lambda=.067, \alpha=.001)$. A bimodal relationship was found between economic motivations and materialism $(\lambda=.113, \alpha=.001)$ : respondents who were either highly materialistic or minimally materialistic had moderate economic moltvation scores.

Associations between consumption orientation and select dependent variables are summarized in Tables 21 and 22. Neither social nor economic consumption motivations were significantly associated with total income, total savings or total debt. Those with 
high sexial motivations had spent more money in the previous 6 months $(\lambda=.053, \alpha=.01)$. A bimodal relationship was found between economic consumption motivations and total purchases $(\lambda=.053, \alpha=.01)$ : those with either very high or very low economic motivation scores tended to have spent less in the previous 6 months.

No associations were found between consumption motivations and the balances of savings or debt in any specilic saving or borrowing mechanism - with the exception of personal savings accounts: respondents with strong social motivations had higher personal savings account balances $(\lambda=.107, \alpha=.01)$. A bimodal relationship was found between economic consumption motivations and the balance of personal savings accounts $(\lambda=.107, \alpha=.01)$ : those with either high or low economic motivation scores tended to have lower savings halances. Respondents with bigh economic motivation scores used their parents' credit cards more frequently $(\lambda=.292, \alpha=.05)$, and repaid parents for purchases made with their credit cards less frequently $(\lambda=.341, \alpha=.01)$

Respondents with high economic motivations more regularly put aside a portion of their income as savings $(\lambda=.089, \alpha=.05)$, were more likely to save their money for specific things $(\lambda=.089, \alpha=.01)$. Social motivations were associated with the extent to which respondents saved money for specific things $(\lambda=.123, \alpha=.05)$-a relationship with a direction only apparent for higher scores: those with higher social motivation scores saved for special things more often. 
Those with high economic or social motivations consulted more information sources before both saving and borrowing. The relationships were stronger, however. with conomic motivations $(\lambda=.069, \alpha=.01$ for saving and $\lambda=.(081$, ( $\alpha=.(0)$ for horrowing) than with social motivations $(\lambda=.057, \alpha=.05$ for saving and $\lambda=.048, \alpha=.05$ for borrowing).

The only particular information source to which consumption orientation was lound lo be related was bank tellers/salespeople. Those with high cconomic consumption motivations were relied more on bank tellers/sakespeople as sources of information lor saving $(\lambda=.117, \alpha=.01)$ and for borrowing $(\lambda=.088, \alpha=.01)$. Social motivations were assixciated only in the savings context $(\lambda=.086, \alpha=.05)$ : higher scores on the social motivation scale were identifiable with either high or low reliance on bank tellers/salespeople as information sources, while those with lower scores were more moderate in their reliance on bank tellers/salespeople as information sources. 


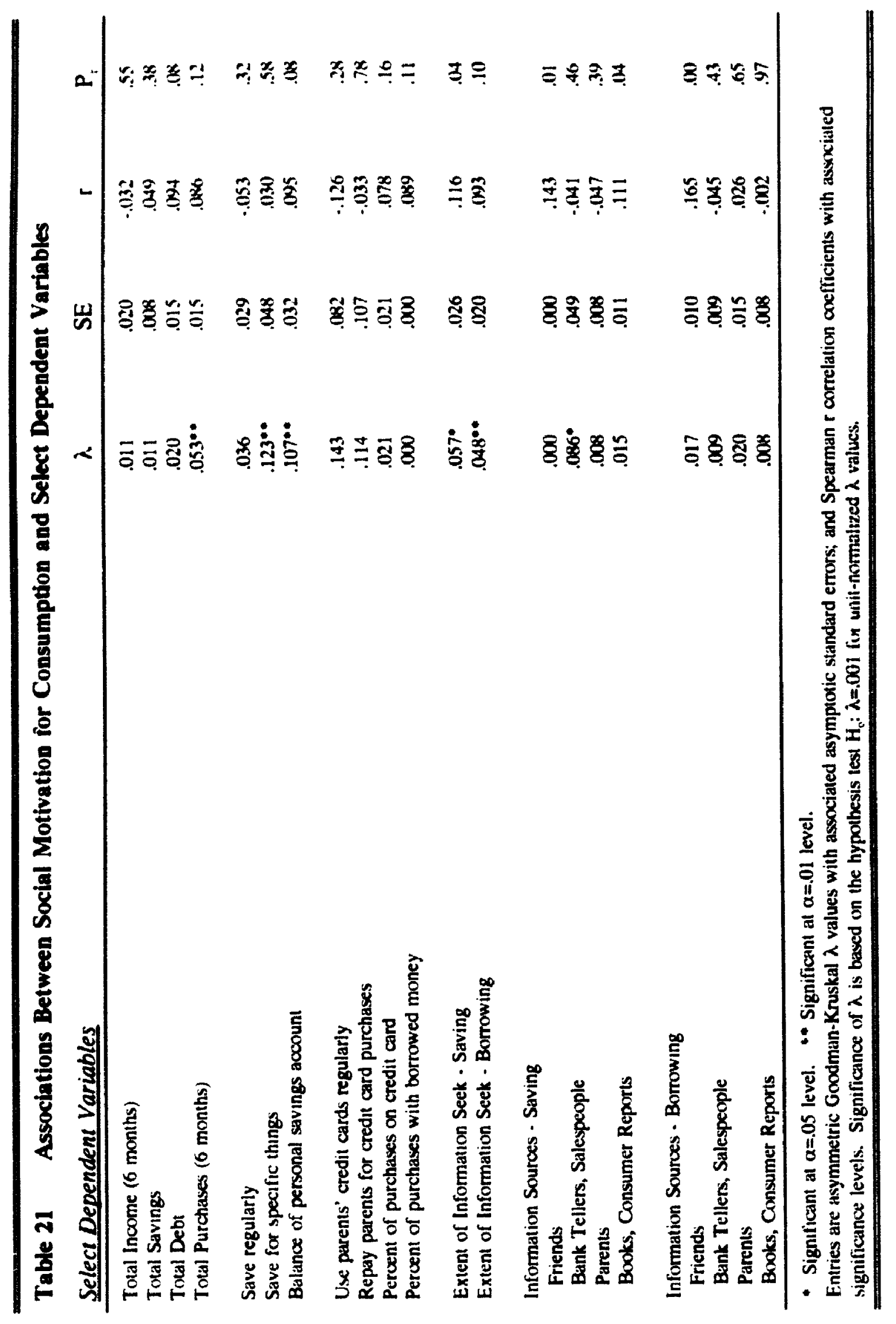




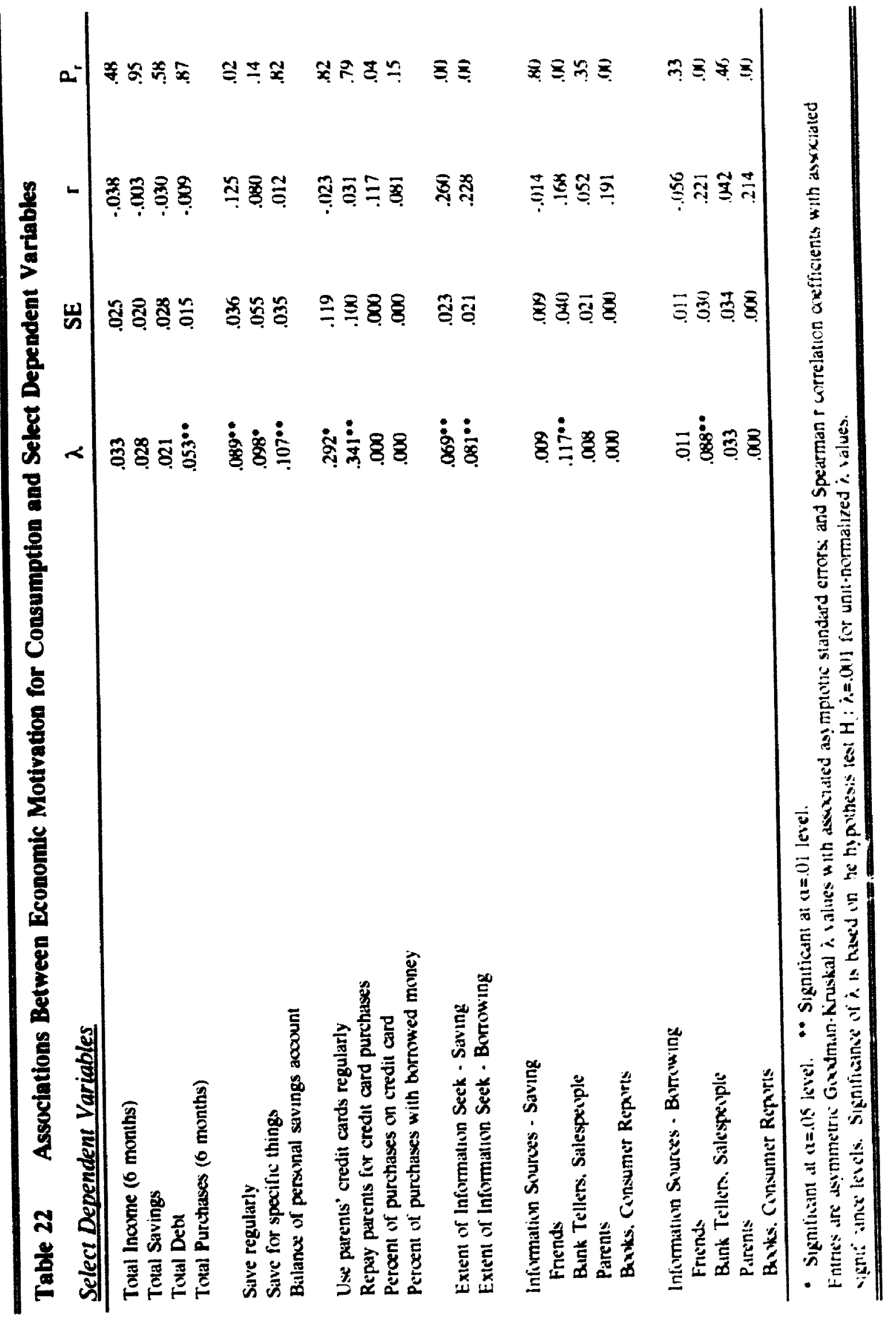




\section{CHAPTER 7: DISCUSSION AND CONCLUSIONS}

A discussion of the results reported in Chapter 6 is presented in this chapter, following which the benefits and limitations of the research are discussed. Conclusions and suggested directions for future research close the chapter.

\subsection{Income}

It was very evident from this study that most adolescents do work, and that they do have significant amounts of moncy to spend. Most respondents (90\%) earned at least some money for themselves over the previous 6 months. Higher rates of employment among teenagers than reported in official statistics were probably found because official statistics report income only from "paid-worker" jobs. Thus, for example, the babysitting jobs held by $30 \%$ of respondents would not be included. Consumer educators are particularly concerned about the number of high school students who are working: an Ontario government commission which studied the high scbool dropout issue in 1988 warned of a link between part-time work and the increasing number of high school dropouts (The Financial Posh 1989). The fact that this study indicates that most adolescents do work therefore has strong implications.

While the incomes reported by respondents were quite notable, the income figures that they reported do not truly reflect the money that they had at their disposal. This conclusion was reached by comparing reported incomes with the total dollar value of the purchases respondents reported as having made during the previous 6 months. The total 
of the purchases that they listed excerded ieported incomes in stre of the cases. On average respondents spent double or triple the money that they reporled as income. It is likely that parents give money to their children to spend, and that this moncy (cither cash or license to use credil cards) is not regarded as "income" by respondents.

Overspending is a common problem in our socicty. Many adults, and lederal, provincial. and municipal governments ofien spend more money than they carn. It might ratse some alarm to know that many adolescents also follow this pattern. This "overspending." however, is arguably covered with intra-household money transfers received from families rather than with debt. This study thus raises the interesting questions of how young people view earned income versus income received from their families, and whether or not they will learn to curb future spending to their levets of income.

Respondents belonging to families of higher socio-conomic status are more likely to have lower eamed incomes, but to spend more money than others. It appears, therckore, that adolescents in higher socio-economic status families receive more incume from families than do others, and thai they rely less on earnings. This was consistent with the finding that those of higher socio-economic status less frequently repaid parents for purchases made on their credit cards, and support for the previous supposition that parents give money to their adolescent children for spending, particularly among the higher socio-economic status. Neitber gender nor age were related to the amount that adolescents earned or spent. 


\subsection{Saving and Borrowing}

The incidence of adolescent saving was found to be much higher than in past research. Over $9.3 \%$ of respondents had a personal bank account of some kind (savings, chequing, or "other"). Marketing rescarch studies from the late 1980 s reported "increases" in tcenage saving bchaviour as a result of finding that $47 \%$ of teenagers had savings accounts (Marketing, 1989), and that by the first year of university up to $67 \%$ had savings accounts (Marketing, 1988). The percentage of respondents in the current study that had saving: accounts was markedly higher $(81 \%)$.

The study showed that many adolescents can be relatively sophisticated in their saving. The frequency of holding bonds was almost double that reported even for first year university students, while the frequency of owning stock was comparable to that reported for first year university students (Marketing, 1988). It may be that more sophisticated savings such as bonds are purchased by parents (with Family Allowance cheques, for example) in the name of their children, to be saved for future educational costs. MeNeal (1987) reported that some of the savings of 4 to 12 year-olds were sometimes put in bonds for them by their parents. This would explain the high correlation that was found between the amount that respondents had saved in bonds and the amounts that they had saved for future education $\left(\lambda=.11, \alpha=.01, r=.32, P_{r}=.00\right)$. Future investigation of the sophusticated savings of adolescents is required. 
More sophisticated savings might not be under the direct control of adolkisecnts, as savings accounts are likely to be. This speculation is hased on the fact that the hallances in personal savings accounts were found to be related to almost all of the independent variables in this study, in many cases when neither total savings nor the balances of savings in other savings mechanism was signilicant. If the individual characteristles iff adolescents (materialism, consumption motivation, agc. ctc.) arc retlected only in balances their personal savings accounts, and not in the balances of their ther savmga, then they arguably have more control over those savings account balances. The exicht lo which adolescents directly and independently control theit finances needs future investigation.

Credit card use was not prevalent among high school students. Very fiw respondents had their own credit cards, and only $23 \%$ reponted ever using a credit card. Approximately $16 \%$ listed some item that they had purchased with a credit card in the previous 6 months. Respondents of higher socio-conomic status used their parents' credil cards lar more frequently than other respondents, and were much less likely to repay their parents for those purchases. This finding was consistent with the fact that those of higher socioeconomic status spent far more moncy than they reported as income. The strong associations found in this study corroborate Hauser (1986), who reported that credil card use was directly correlated to family income.

Borrowing, especially from friends or parents, was found to be very prevalent among high school students. Almost $70 \%$ of respondents had borrowed from parents or friends in the 
past. No previous studies had indicated how frequently adolescents might be expected (1) use these sources of deht. Slightly more respondents owed money to friends than to parents (33\% vs. $23 \%$ ), hut the amounts owed were substantially lower for friends than for parents (median $=\$ 20$ vs. $\$ 97)$.

An isstl: that tnis research did not address was repayment of borrowed money. It would be interesting to $1 ., w$, especially since most of the debt found in this study was of an informal nature (borrowed from family of friends), how much of the money "borrowed" from Iriends and parents is ever repaid. One might speculate from the previous discussion of credit card repayment, that many respondents would sometimes not repay their debts, especially to parents, in order to finance their high levels of purchasing. Knowledge about payment practices among adolescents is important, for their luture creditors might not be as forgiving as they might lind their parents to be.

\subsection{Information Sources}

The number of sources of information that respondents would consult before saving or borrowing was similar to that found by Moschis (1978b) in the purchasing context. On average, adolescents consulted onc or two sources of information. This number might be considered low given that adolescents are arguably less informed about financial options and morc lamiliar with product-oriented purchasing situations. Indeed, a consumer knowledge le's of high school students in the United States, conducted by the Consumer Federation of Aincrica (1991), revealed that students were "particularly uninformed" about 
credit, and chequing/savings accounts. Students dud most perorly on "Itens testmg specitic knowledge of products, espectally that related u linancial services."

In general, respondents consulted more infiormation soures before siswing in mote sophisticated ways (i.e., stociks, bonds). Funhermore, those of higher socererenthmle status, and those with higher social and conomic consumptun moltvations, lended to consult more information sources. These tindings are similar to the purchasing context: adolescents of higher socio-economic status look for more information precedung purchases (Moschis, 1978b), and are less independent in purchasing (Moschs, Monte, allul Stephens, 1977; Saunders, Salmi, and Tazier, 1973).

Almost all respondents indicated that they would rely on parents fier financ!al informatim, and about $75 \%$ indicated that they would rely on bank tellers/salespeople. Irichd would generally be consulted for information only in the case of borrowing moncy trom a pawn brokerage. All other sources of information would be consultal by between 30 and $410 \%$ of respondents.

Respondents of higher socio-economic status were lound by Moschis to rely more on parents as sources of information when purchasing because, It was thought, the se parents take more care in teaching thesr children the behavours that are decmed approprate: Io that status (Moschis, 1978b). Parents were a source of intormation for virtually every 
respondent $(97 \%)$ in this study, so variations by independent variables were not detectable.

Past studies of purchasing reference sources indicated that in general adolescents were becoming less dependant on their parents, and more on their peers (Gilkison, 1973), but this was definitely not the case in the saving and borrowing context. Gilkison's findings, however, varied over the product classes which he investigated. The products which Gilkison examined were: a variety of consumer durable goods (personal clothing, toiletry articles, sports equipment, and small appliances), insurance policies, and forms of transportation. Insurance policies are conceptually closer to borrowing and saving mechanisms than other tangible products, and, not surprisingly, only in the case of insurance policies were parents listed as the strongest, and sales people as the second strongest, frame of reference as was found in here in the saving and borrowing context. Thus (iilkison's (1973) conclusions corroborate the findings of the present study.

It is likely that social pressures are far lower for financial decisions than for purchase decisions, which have more tangible consequences; if so, the need for peer conformity and the associated information requirements need not exist. On the other hand, adolescents may liel that their peers simply do not possess the financial information that they seck. While the reliance of respondents on peers for information about pawnbrokers could be due to the perception that such services are somewhat illegitimate, no conclusion can be supported with the data that were collected. 
Age was almost completely unrelated to other variables in this study. It was relalled only to the balance of personal savings accounts. Past studies of adolescents had shown income to increase with age (Ward, Wackman and Wartella, 1477; McN(ail, 14877), and the extent of saving to increase with age. Past studies had also shown thalt older adolescents tended to actively seek more informatior before making purchatse decisions (Moschis 1978a; 1978b). The absence of some of these relationships in the saving and borrowing context is perhaps understandable given the fact that some of these past studies used samples of younger children (ages 4 to 12). Furthermore, the age distribulion in this study was quite heavy-tailed: a very large proportion of respondents fill within the narrow age range of 15 to 18 . It is likely that the financtal situation of each adolescent does not vary much over the few years that he or she is in high school.

Gender was not a significant variable in this study. Past studics have found significant differences between genders in terms of income, spending, saving, inlormation secking. and even materialism and consumption motivation, but not one significant relationship was found in this study- - neither for the sample as a whole, nor for any particular sch(o)l. Since no significant differences were found between schools, even though the sampled proportion of male to females varied considerabiy, a gender selection bias deses not seem likely. The fact that gender was not significant may be duc to kess gender stercotyping among younger generations, and therefore less socialization into typical gender reles ol the past. It appears from this study that among high school students gender differences have disappeared, at least along the variables that were considered. 'This 
speculation is by no means conclusive, however, and more research into this area would be needed betore reaching a conclusion.

Sxcio-economic status, materialism, and social and economic motivations for consumption all served as predictors of the dependent variables in this study. Al times these relationships were not straightforward. These variables interacted with one another, so as to make it difficult at times to determine which variables were really influencing which. These complex relationships and inter-relationships need to be studied further.

\subsection{Benefits of the Research}

This study is of benefit to consumer educators, consumer behaviour researchers, financial institutions, public policy makers, and retailers. Consumer education literature has revealed that consumer educators in particular are concerned about the extent to which students work, and about the possible negative effects of the "premature affluence" that is arguably the result of large amounts of money that youths control. This study investigated how teenagers manage the money associated with this work and affluence. It was intended to be of value in identifying some of the issues about which consumer educators should be concerned. There can be no means of designing programs to help educatc students without accurate readings of how students actually behave.

A recent consumer knowledge test (Consumer Federation of America, 1991) has indicated that levels of consumer knowledge about financial activities is quite low among high 
school students. The level of responsibility that youths are displaying in theor financial activities cannot be determined from this rescarch, but consumer educiatos would be well advised to keep in mind the significant extent to which their students are financially active: eaming, saving, and borrowing are extremely prevalent, regardless of how prepared adolescents are for it.

Academics in the fields of consumer socialization and adolescent consumer behaviour ean benefit from this research, as it has explored an area that has lacked attention. This study can serve as a foundation for research which explores the socialization agents from which adolescents learn to borrow and save, and for more in depth analysis of what inlluences this behaviour. Such research is important in gaining an understanding of these kearning processes and the means by which these processes can be influenceal. Saving and borrowing behaviour and information sources were found in some cases to be similar and in others dissimilar to the purchasing context. These differences and similarities should be kept in mind in future explorations. Furthermore, much of the research from which this study developed is dated, and needs re-examination. Gender did not interact, for example, with other independent variables in this study: whether the same would hold true in a contemporary study of consumer sccialization and purchasing remains to be seen.

Financial institutions can benefit from understanding adolescent borrowing and saving, behaviour, the reasons for such behaviour, and the extent to which they, and others, 
influcnce it. Alrcady financial institutions are catering to the specific needs of the younger gencration, not only with special services, but also, in some cases, with entire banks dedicated to this market segment. Even better services for adolescents could result from studies of which investigate the financial activities of these young clients. Financial institutions might consider that many adolescents have their own savings accounts, and that almost all have a bank account of some sort. Some high school students also demonstrated that they can be quite sophisticated in their savings behaviour: financial institutions should keep this fact in mind when servicing this market.

Retailers can benefit from the knowledge that adolescent saving and borrowing are common: most adolescent saving is intended for specific product purchases, - purchases expected to be worth $\$ 10$ billion in Canada by the year 2000 . Furthermore, retailers sioculd be aware that a significant percentage of adolescent purchases are made with parents' credit cards.

Public policy makers should consider that fact that most adolescents work, and that many can be very sophisticated in their employment and financial activities. Current policies, such as restrictions on adolescents from participating in traditionally "adult" activities (c.g. starting a business), might be questionable in light of this fact. 


\subsection{Limitations of the Research}

The main weakness of this study is its limited generalizahility. hoth in kerms of geography and sample selcetion. The limited geographical area in which it was carricd out and the use of an inexhaustive sampling frame must be noted. Ottawa-Hull is the second most affluent city in Canada, with per capita income $24 \%$ above the national average: tinis fact must be considered if the results of this study are generalized, since socio-economic stattus was found to be a very significant variable. With this proviso, it is probahly sale II generalize the study to the Ottawa area.

\subsection{Conclusions and Directions for Future Research}

"If the financial arrangements within households could be shown to alfect how much is spent, by whom, and on what items, this would be both of great academic and commercial significance" (Pahl, 1986). This study addressed only a sma!l part of an intra-family economy and consumer socialization issuc, but, as an attempt to examme some of the variables in the adolescent purchasing process, it was useful in identilying areas deserving of future research.

Future researchers might look more closely at the control that adolescents have over thesr finances, and intra-family money flows which seem to subsidiec the earned incomes of adolescents. A stronger link could then te made to research about intra-lamily ecunomy and control of income, spending, saving and horrowing within the lamily urit. (Jucstions about whether adolescents would save to the same extent (e.g, for future coducation) if it 
was left totally up to them could then be addressed. It would also be useful if future researchers euuld make stronger links to socialization theory in terms of how children and adolescents actually learn to control their money: the examination of variables such as socio-economic status, materialism, and age in the financial context was a valuable first slep wwards understanding of the financial processes and influencers of these processes among adolescents. 


\section{REFERENCES}

Abramovitch, Rona, Jonathan Freedman, and Patricia Pliner ( $|\Psi\rangle \mid)$. "Children and Money: Gettin's an Allowance, Credit Versus Cash, and Knowledge of Pricing," Jomrnal of Economic Psychology, 12 (March), pp. 27-45.

Bachman, Jerald G. (1983), "Premature Affuence: Do High Sch(x)l Siudents liarn 'lin) Much? Economic Outlook USA, (Summer), pp.64-67.

(1987) "Adolescence: An Eye on the Future," Psychology Todav (July), pp.6.8.

, Lloyd Johnston, and Patrick O'Malley (1967), Monitormg the Fiuture: Questionnaire Responses from the Nation's High School Seniors, 1980. Ann Arbor, MI: Institute for Social Research.

Bivens, Gordon E. (1979), "The Family as an Economic Entity: Some Evolving Observations," Economics and the Family, Stephen J. Bahr (ed.), Toronto: I exington. pp. 1.9.

Boyd, Monica, and Hugh A. McRoberts (1982), "Women, Men and Sxxio-ficonomic Indices: An Assessment," American Association for the Advancement of Science Sedected Symposium, 1981. Boulder, Colorado: Westview Press.

Bresnick, David (1984), Youthjobs, Westport, CT: Quorum Books.

Cambell, Earnest, Q. (1969), "Adolescent Socialization," Handbook of Soctalization Theory and Research, David A. Goslin (ed.), Chicago: Rand McNally and (impany.

Cateora, Philip R. (1963), An Analysis of the Teenage Market. Austin, Texas: Burcau ol Business Research, University of Texas. 
Cole (1980), Working Kids on Working, New York: Morrow.

Consumer Federation of America (1991), "Student Consumer Knowledge: Results of a Nationwide Test."

Cooncy, Roscmary S., Alice S. Claguc, and Joseph Jr. Salvo (1982), "Status Attainment of Young White Men and Women: Two Socio-Economic Measures," American Association for the Advancement of Science Selected Symposium, 1981. Boulder, Colorado: Westview Press.

D'Amico, R. (1984), "Doxes Employment During High School Impair Academic Progress?" Sociology of Education, 57, pp. 152-164.

Dal Cin, Patrizia (1992), "Decusion-Making by Canadian Informal Investors: Findings Regarding the Impact of Experience," Proceedings from the ENDEC World Conference Entrepreneurship, Singapore.

Davis, Duane, and Robert Cosenza (1988), Business Research for Decision Making. Boston, MA: PWS-Kent Publishing Company.

Douthith, Robin A., and Joanne M Fedyk (1988), "The Influence of Children of Family Life Cycle Spending Behaviour: Theory and Applications," Journal of Consumer Affairs, 22 (Winter), pp. 220-248.

Eiser, RichardJ. (1986), Social Psychology: Attitudes, Cognitions, and Social Behaviour. Cambridge: Cambridge University Press.

Featherman and Stevens (1982). "A Revised Socio-Economic Index of Occupational Status: Application in Analysis of Sex Differences in Attainment," American Association for the Advancement of Science Selected Symposium, 1981. Boulder, Colorado: Westview Press. 
Financial Post Daily (1989), "Young money: spending power of teens his rix.kitld," "Business takes aim at huge market," April 24, pp. 15, 20.

Fortune (1989). "The ABC's of Marketing to Kids," 119 (May 8). pp. 11+-120.

Foxman, Ellen R., Patriya S. Tansuhaj, and Karim M. Ekstrom (1989), "Famıly Memilu.r" Perceptions of Adolescents' Influence in Family Decision Making." Journal of (omsume"' Research, 15 (March), pp. 482-491.

(1989b), "Adolescents' Influence in Family Purchase Decisions: A Sixialızalliulı Perspective," Journal of Business Research, 18 (March), pp. 159-172.

Gilkison, Paul (1965), "What Infuences the Buying $\Gamma$ isions of Teen-agers?" Journal of Retailing, 42 (Fall), pp.25-37.

- (1973), "Teen-agers' Perceptions of Buying Frames of Relerence: A Deciade in Retrospect," Journal of Retailing, 49 (Summer), pp.25-37.

Globe and Mail (1991), "Teen pockets run deep: Billicn dollar market eluding retaikers, marketers," March 5, pp. B1, B2.

(1989), "Young pleasure scekers born to shop, study says," Jaruary 27, p. I36.

Greenberger, E (1988), "Working in Teenage America," Work Experience and Psychological Development Through the Life Span," J.T. Mortimir \& K.M. Burman (Eds.). Boulder, CO: Westview Press, pp. $21-50$.

and Laurence Steinberg (1986), When Teen-agers Work, New York: Basic Burkks, Inc., Publishers. 
(juber, Selina S. (1987), "The Teenage Mind," American Demographics, 9 (August), pp. 42-44.

Hall, Carol (1987), "Tween Power: Youth's Middle Tier Come of Age," Marketing and Medea Decisions, 22 (October), pp. 56-62.

Hauser, Grady (1986), "How Teenagers Spend the Family Dollar," American Dermographics, 8 (December), pp. 38-41.

Heisler, Jerry (1990), "From CDs to CDs: Reaching the Teen Market," Bank Marketing. 22 (April), pp. 34-35.

Helitzer, Melvin, \& Carl Heyel (1971), The Youth Market. New York: Media Books.

Kinnuar, Thomas C. and James R. Taylor (1987), Marketing Research: An Applied Approach. New York: McGraw-Hill Book Company.

Marketing (1986), "New Perspectives on the Teen Market," June 16. p. 9.

(1988), "Students - A Market Growing Up," September 19, p. 10.

(1989). "Teen Consumers," September 4, p. 3.

(1990), "Teenagers: Power In Numbers," February 19, p. 10.

(1991a), "Youth Culture Is Key to a Huge Market," August 5, p. 5.

(1991b). "Teen Market Offers Growing Opportunities," November 18, p. 18.

(|cy|c). Teen Loyalty Targeted with a Variety of Promotions," December 16, p.

18. 
McNeal, James U. (1969), "The Child Consumer: A New Market," Journedl of Re'tuling. 45 (Summer), pp. 15-22.

(1979), "Children as Consumers: A Review." Journal of the dicade'mi of Marketing Science. 7 (Fall), pp. 346-359.

(1987), Children as Consumers, Lexington, MA: Lexinton Binks.

(1988), "The Children's Marheh" Incentive, 162 (September), pp. s7-1)6.

36-39.

(1990), "Children as Customers," American Demographics, 12 (S.pkemterr). pp. $36-39$

and Chyon-Hwa Yeh (1990), "Taiwanese Children as Consumen," Furopean Journal of Marketing, 24 (October), pp. 32-43.

Moore, Roy L and Lowndes F. Stephens (1975), "Some (iommunicialion and Demographic Determinants of Adolescent Consumer learntng." Journal of cionsumer Research, (Seplember), pp. 80-92.

Moschis, George P. (1978a), "Teenagers" Responses to Retailing Sumulı," Journal of Retailing, 54 (Winter), pp. 80-93.

(1978b), Acquisition of the Consumer Role By Adolescents. (joorgia: (ollege of Business Administration, University of Georgia.

(1985), "The Role of Family Communication in Consumer Sxcialifation of Children and Adolescents," Journal r, C Consumer Research, 11 (March), pp. X'sk-413.

(1987), Consumer Socialization: A Life-Cycle Perspectue, Iexington, MA: D.C' Heath \& Co. 

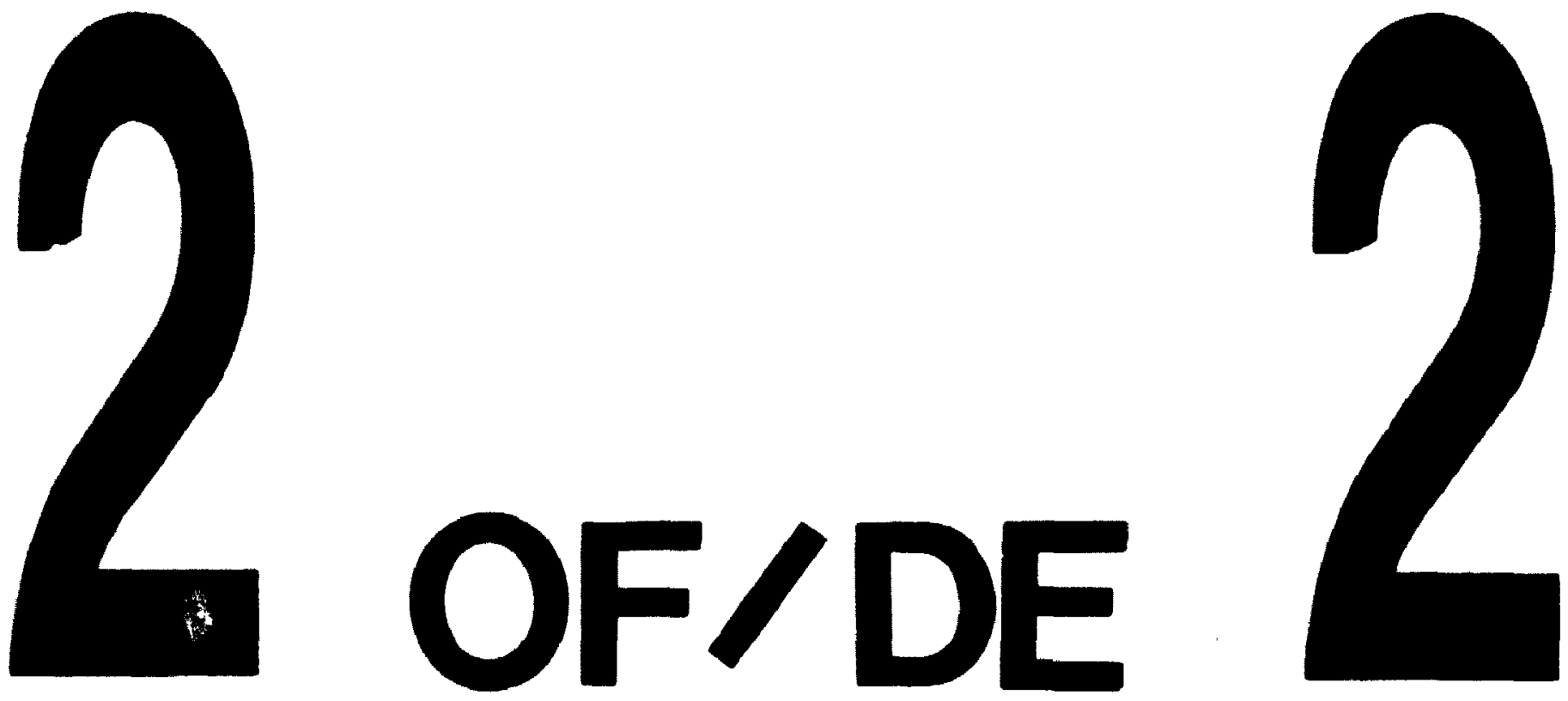

PM-1 3', 'x4" PHOTOGRAPHIC MICROCOPY TARGET NBS 1010s ANISI/ISO "2 EOUIVALENT

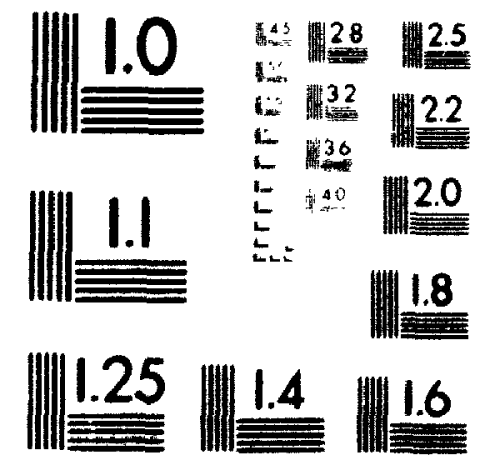



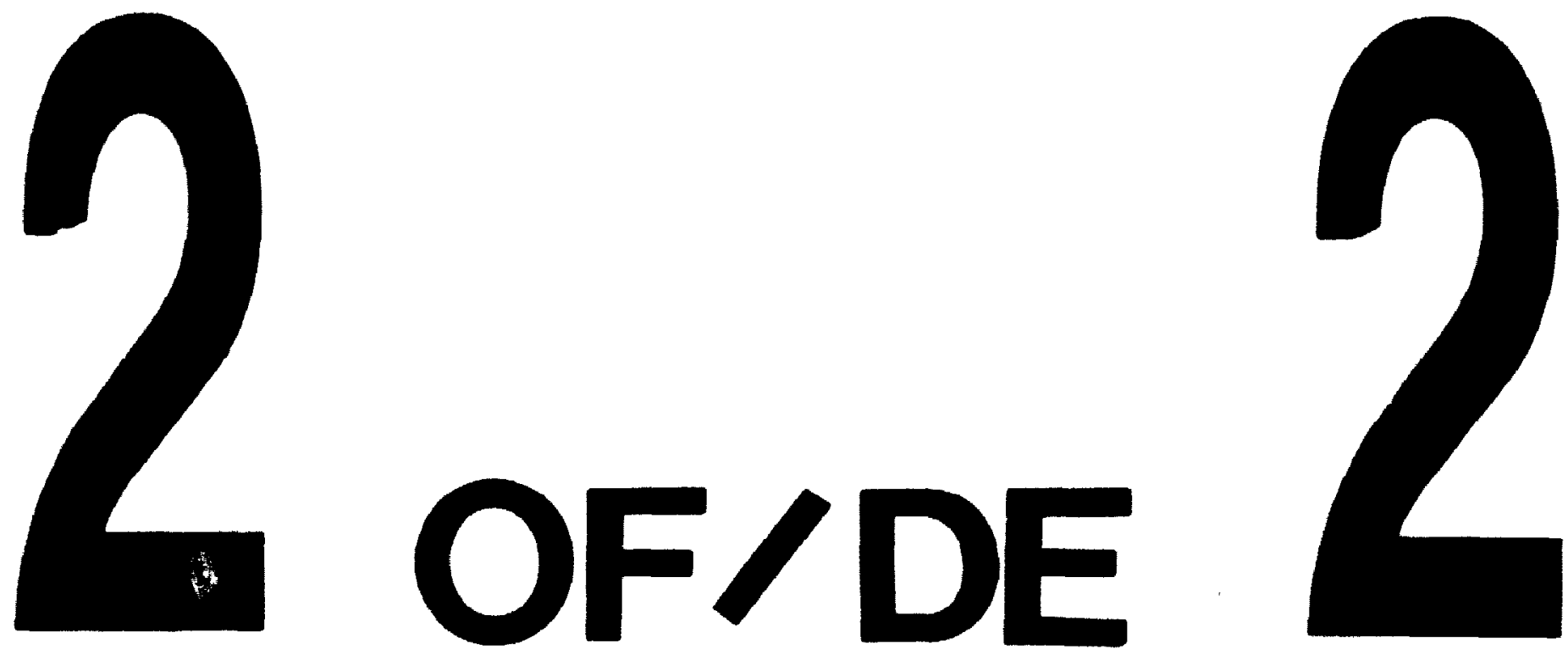

PM-1 3\%" "X4" PHOTOGRAPHIC MICROCOPY TARGET MBS 1010a ANSI/ISO "2 EOUIVALENT

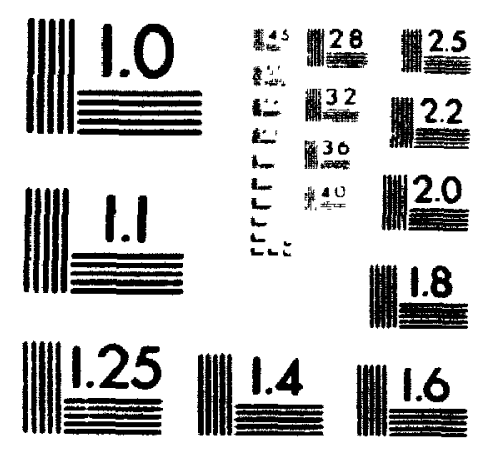


- Roy L. Mcore, \& Lorondes F. Stephens (1977), "Purchasing Patterns of Adolescent Consumers," Journal of Retailing, 53 (Spring). pp. 17-20. 92.

and Roy L Moore (1978), "An Analysis of the Acquisition of Some Cousumer Competencies Among Adolescents," Journal of Consumer Affairs, 12 (Winter), pp. 276291.

Mortimer, Jeylan T. (1991), "Employment," Encyclopedia of Adolescence', Richard I irncr. Anne Peterson, \& Jeanne Brooks-Gunn (eds.). New York: Garland Publishing Inc.. pl. 311-318.

Murphy, Sue (1987), "Generate Services for Each Generation," Credit Union Magarine. 53 (October), pp. 50-58.

Pahl, Jan (1989), Money and Marriage, London: MacMillan Education L.td.

Peter, J. Paul and Jerry C. Olson (1987) Consumer Behaviour: Marketing Strat'gy' Perspectives. Homewood, IL: Irwin.

Phelan, Gladys K. and Jay D. Schvanevelot (1969), "Spending and Saving Patlerns of Adolescent Siblings," Journal of Home Economics, 61 (February), pp. 1(14-1(4).

Powers, Mary G. (1982), "Measures of Socio-Economic Status: An Introductun," American Association for the Advancement of Science Selected Symposium, I98I. Boulder, Colorado: Westview Press.

Rao, J.N.K and D. Roland Thomas (1988), "The Analysis of ("ross-Classified Catcgorical Data from Complex Sample Surveys," Sociological Methodon'ngy, 18, pp. 213-269.

Reubens, Beatrice G. (ed.) (1983), Youth at Work: An International Survey, Totawd, NJ: Rowman \& Allanheld Publishers. 
Sage Publications (1977), "Analysis of Nominal Data," Quantitative Applications in the Social Sciences. Beverly Hills, CA: Sage.

(1983), "Measures of Association," Quantitative Applications in the Social Sciences. Beverly Hills, CA: Sage.

(1987), "How Many Su'jjects?" Quantitative Applications in the Social Sciences. Beverly Hills, CA: Sage.

Saunders, Josephine R. (1973), "Congruence and Conflict in Buying Decisions of Mothers and Daughters," Journal of Retailing, 49 (Fall), pp. 3-18.

Schindler, Martha (1989), "Institutions Tap a Pint-Soze Market to Woo Depositors," Savings Institutions, 110 (February), pp. 83,85.

Shcrif, Muzafer and Carolyn Sherif (1964), Reference Groups: Exploration into Conformity and Deviation of Adolescents, New York: Harper and Row.

Sheth. Jagdish N. (1983), "Emerging Trends for the Retailing Industry," Journal of Retailing. 59 (Fall), pp. 6-18.

Statistics Canada (1989a), The Nation-Labour Force Activity, Catalogue 93-111, Ottawa: Canadian Governement Publishing Centre.

(1989b), The Nation Total Income: Indivuduals, Catalogue 93-114, Ottawa: Canadian Governement Publishing Centre.

(1989c), Canada's Youth: A Profile of their 1986 Labour Market Experience, Catalogue 71-207, Ottawa: Canadian Governement Publishing Centre. 
Stipp, Jorst H. (1988), "Children as Customers," American Demographics. 10 (liebtuary). pp. 26-32.

Tootelian, Dennis, \& Nicholas Windeshausen (1976), "The Teen-age Market: A Comparative Analysis, 1964-1974," Journal of Retailing, 52 (Summer), pp. 51-(x). 92.

Vandermerwe, Sandra (1990), "Youth Consumers: Growing Pains," Busine'ss Horizums, 33 (May/June), pp. 30-36.

Walker, Robert (ed.), (1985), Applied Qualitative Research, Hants, Fngland: Gower.

Ward, Scott, Daniel Wackman, \& Ellen Wartella (1977), How Children Learn io Bay. Beverley Hills, CA: Sage Publications.

Weinstein, Grace W. (1975), Children and Money: A Guide for Parents, New York: Charterhouse. 


\section{Appendix A: Research Questions}

Q1: Do any of the following serve as information sources for adolescent saving and borrowing: parents; friends; salesmen or bank tellers; brochures or newspaper and magazine ads; television ads; or books and consumer reports?

Q2: How do materialist values affect adolescent borrowing and saving behaviour and information seeking?

Q3: How do consumption motivations affect adolescent borrowing and saving behaviour and information seeking?

Q4: Are there gender differences in adolescent saving and borrowing hehaviour or information secking?

Q5: Are there age differences in adolescent saving and borrowing behaviour or information seeking?

Q6: Are there socio-economic differences in adolescent saving and borrowing behaviour or information seeking?

Q7: How can adolescent borrowing and saving be described?

i) Why do adolescents save?

ii) Why do adolescents borrow?

iii) What is the extent of adolescent saving?

iv) What is the extent of adolescent borrowing?

v) What saving mechanisms do adolescents use?

vi) What borrowing mechanisms do adolescents use? 
Appendix B: Survey Instrument 


\section{Carleton University}

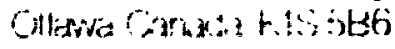

A number of recent ntarksting reasedch studies have found that high school stiulents edrn and antrial more mosey tuday than they ever have done in the past. Very littie is knuwn, ho.wever, alout huw students manuge their money and make decisions abuut how tor spend it.

I an prisently cundin ling a study tor my thesis on how young pexple manage thir money "fectiti ally, I an misrested th the saving and borruwing practices of high

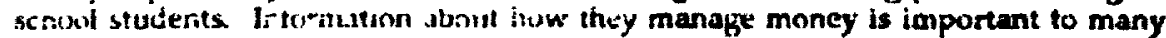
pieple, inc ludıy; high schoul students themaclves, parents, schools, marketers, and

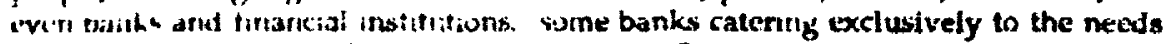
of exendets have cpencd recertly in the linted Sultes.

The sfidy requen partieliduc trom a comprehensive sample of high school studerts, the schwol oour! has given me pirmisyion to gather date in the schurols.

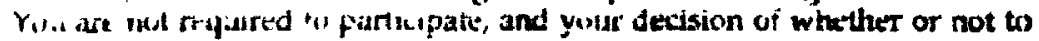

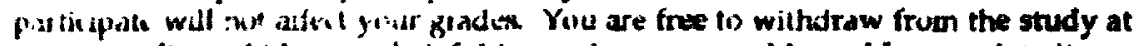
any time. I: woild bo very helpful so ine, however, and I would appreciate it very inuch, if you wuuld take the turke to fill in this questionnuiss. It will take you approximately 30 minutes 1. answer all the questions. lou can take it home with you and fill it out there. Please seal the questurnaire in the envelope it came in sind bung it back to hume-roum umorrow or within the next few days and leave it with your leacher.

lin can tre dswured that your ans: vers will be completely confidential. Your name dires rot appeiu on the quastunnaire, so no one will knun which one is yours. row teacter will NOT re'is the guestionnairs. I wili combine answers from all iespondents and my thesis wili report anly ors the combined dato Individual responses will NOT be identified.

Mas1. gerple ure mirested in the results of research that they participate in If you nuwid like to rexive s brit summary of the research revits, you will be able to pick a copy up from your schoot wifice. I will leave copies there when I finish the in wearch in lanuary. I would be plesused to answer any questions that you might have: My jhom number is on the front cover of the questionnaire.

Thank yeal very murh ior your help.

Since:ely.

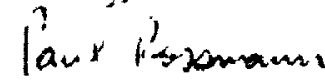

Paul Rassiminn

M.MS student, Schori of Business

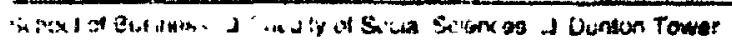

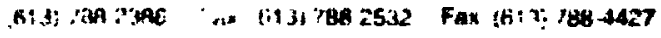




\section{Carleton University}

Ottawa, Canada, K1S 5B6

Pleave answer all the questions, seal the questionnaire in the provided envelope, and deposit the sealed envelope in the larger envelope that your tescher has for the purpose.

Plesce retum the queetionnaire tomorrow or within the next few days, bui no later than

All information will be completely anonymous and confidential.

Thank you for your help.

Paul Rossmann, B.Comm.

Graduate Student

School of Busines;

Carleton University

526-1243
Judith Marshall, Ph.D.

Thesis Supervisor

School of Businese

Carleton University

788-6654 


\section{SECIION A: INCOME}

The folluwing questuons rel.jte to your income and the scurces of your income. When answering the quertiuns please think doust ALL of the money that you receiver allowances or noney that your parents give to you, money earned from part-tume pobs, babysittins and uth,er odd jobs, cash gafts, etc..

1. What was your incoine from all sources for the lust 6 morthe?

2. Hono much of this monry did you get from the jollowing pluces?

a. Full-tune summer job

b. Part-time or temporary summer job

c. Part-time job during schnol year

d. Babysitting

e. Allowance

f. Gifts of money

g.Other (specify):

h. Other (specify')

i. Other (specify):

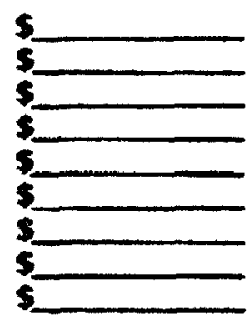

3. What was your income last month (October)? $\$$

4. Where did your incume for lnst month conte from?

a Part-tume job

b. Babyritting

c. Allow ance

d. Gits of money

e. Other (specify):

f.Other (apecify):

g.Other (specify):

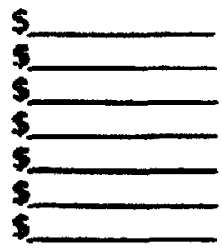

5. How much of last month's income do you still heow? 
SECTION B: BUVNG DEHAVIOUR

The following questions relate to your buying behaviour. The first part of this section asks about somt of your genteral artitudes about money and buyine and the second part asks about what thuns you consider when buyng different prodicits.

6. For each of the fullowing statemenis plowze circle the number to show the exient to twhich you egree or disegree.

a. It is really true that muncy

Strongly

agree

can buy happiness.

b. My dream in life is to be able to own expensive

things

c. People judge othecs by the things they own.........................

1

d. I buy some things that I secretly hope will impress other people

e. Money is the mast important thing lo consider in choosing a job.

f. I think others judge me as a person by the kinds of products and brands I use......

8 I really don't think it's right for others to judge me as a person by the kinds of products and brands I use....<smiles>C[As]</smiles>

i

1

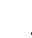

1

1

1
2

3

4

$\mathbf{s}$

Strongily

divagree

5

4

4

5

2

3

4

5

2

3

4

5
2

3

4

5 
7. Thie queation contans a list of 5 products, as sell as a list of things thit may or muly not important for you to know kfore buying ench of the products. For each item that yun read on the list check whecher You think it is imporrant to

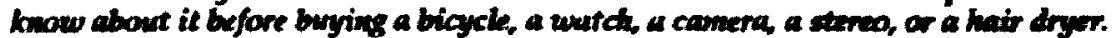
(FOR EACH ITEM TILAT YOU READ YOU MAY CHECK AS MANY PRODUCTS AS YOU WANT, OR NONE OF THE PRODUCTS.)

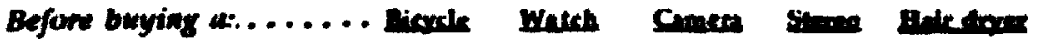

It is importient 10 knows

a. What freends think of different brands or products..............

b. Cuarantees on dufferent brands.......

c. What kinds of people buy certain brands or producte.............

d. The name of the company that makes the prodict. .........

c. Whether any brands are on sale. . . . . . . . .

6. What othere think of people who use certain brands or products..............

8. Kinds of moterials different brands are made of ..........

h. What brand" or products to buy to make good impresion: on others. . . . . . . . . .

i Quality of the store selling a particular brand.............. 


\section{SECTION C: : : VING}

The following questions are about twow inuch of your money you save, where you save, what information you want in order to decive huw to save, and where you get this information from. Pleasc answer all questions as directed.

8. How mudi mutey do you corrently hare saved IN TOTAI. counting all of your personal suvinge and insestments?

\section{$\$$}

9. Do you sare in the following ways? Check YHS or NO for anch item and enter the bulance of your sovings (as of loday) for each itrm that you have checked res.

- Your parents' bank accuunt

b. Your own beirck account

10. During the last mombh, did you put any monery aside specifically for anoing?

Savings account

Chequing account

Other bank account

c Term depusit: (CICs, CDw)

d. Bonds

e. Mutual funds, stocks, or uther inveutments

f. Other (xpecify):

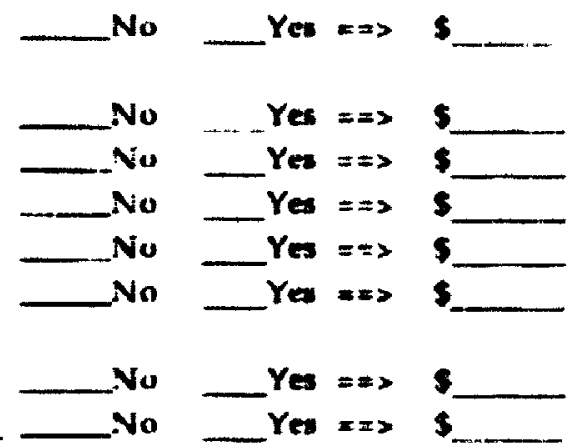
No

Yes $=3$ How mucht

11. Pleace cincle the number that best describes the extent to which you do the following thing:

2. I regularly put aside a portion of the Never incume that I receive as savings..... I I

b. Whan I ave moncy, I save it for specific things. . . . . . . . . . . . .

1

Nways 
12. Below are listed enme of the things that you mught woe for. Check mext to each item if you are currently woung for it, und wnie how much you have seved for it so for.

rraM

AMOUNT SAVED
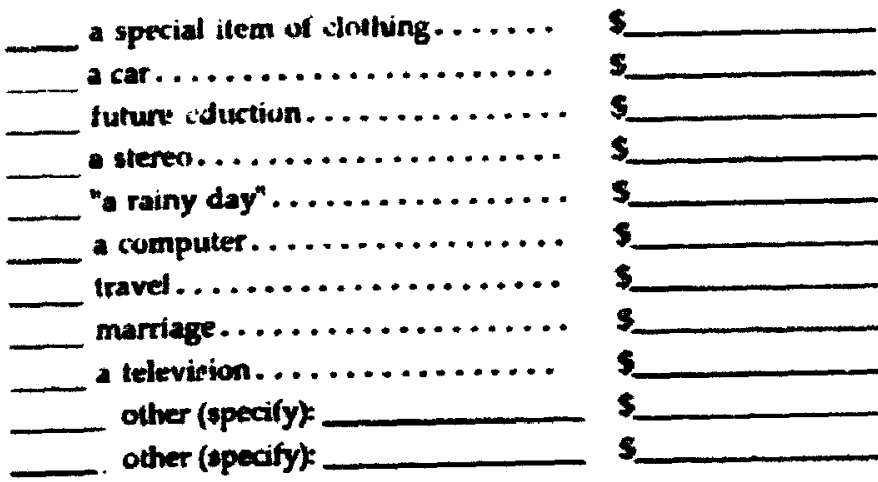

13. Debo wre tisted some of the worys that people save money. For each one check thase prople or other information suras that you would rely on mast for

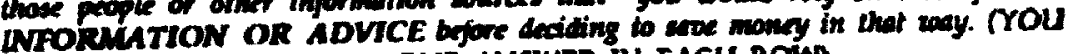
MAY CHECK MORE THAN ONE ANSWER IN EACH ROW).

Sounce of Inforntion

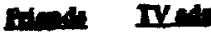

Selengerple.

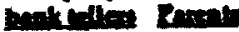

Doole Dochuses

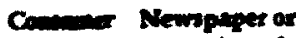
5.1 mentring

Howeres

a. Parents' bank account

b. Your own bank account:

Saving account Chequing account

Other bank account

c. Term depoults (CIC, CDs)

d. Bands

e Mutual funds, stucks, or other investment:

COther.

(specify):

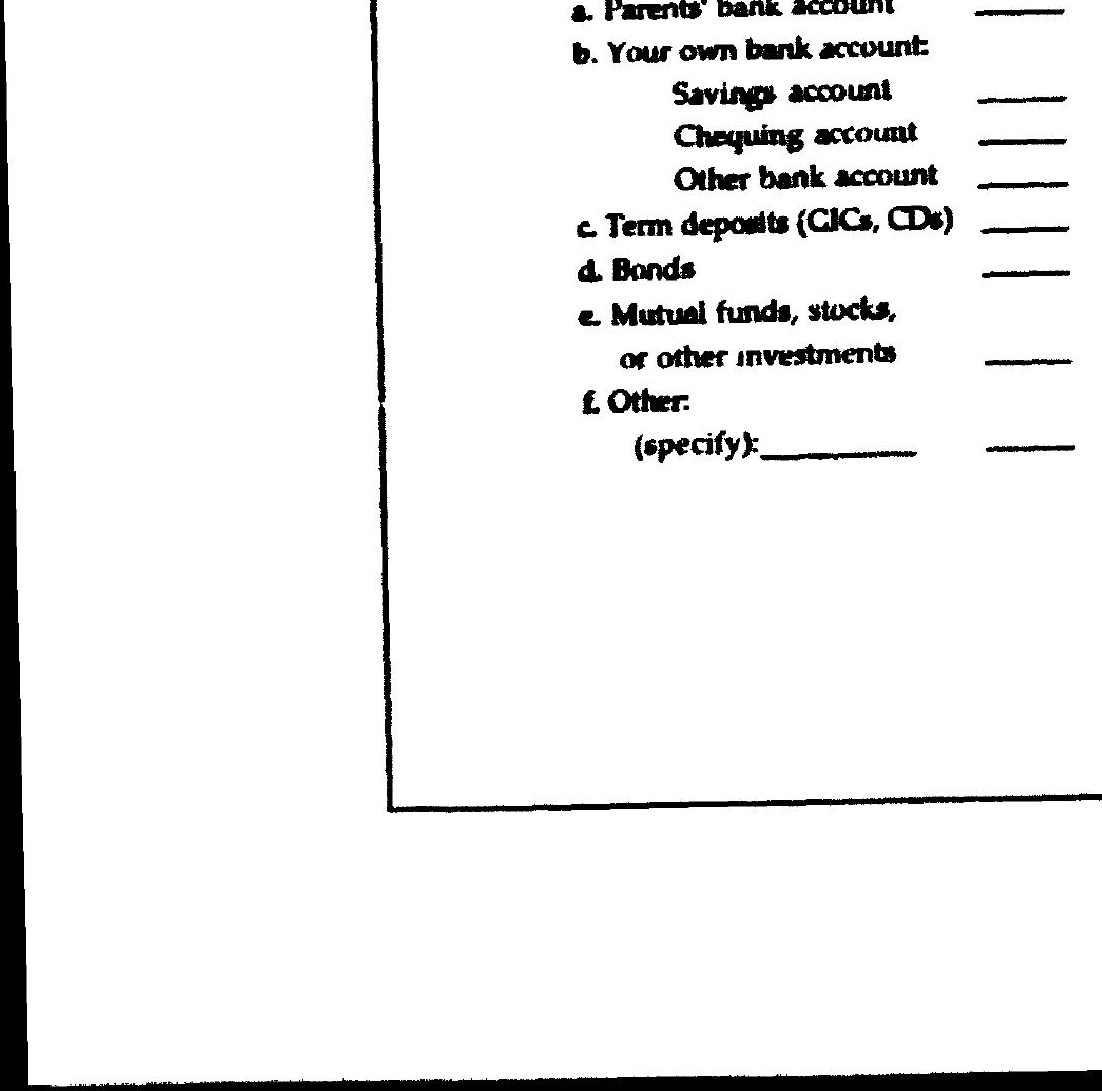


14. Have you ethet tricd to open un account at a five. II rastitutio. and been refused?

$\longrightarrow$ Nos $==2$ Whete?

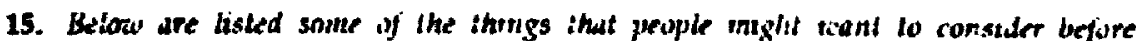
saung their money at a purticutor tand or finuaciul institution. For cach one check how ismportant at awould in for you to find oul athnt it before decading to save your momey ihere. When deciding how important each is, chink about how hand you woutd try to get che information of you did not have it.

\begin{tabular}{|c|c|c|c|c|}
\hline $\begin{array}{c}\text { Very } \\
\text { Important } \\
\text { To Find Ohat } \\
\mid\end{array}$ & & $\begin{array}{c}\text { Neutral } \\
\text { | }\end{array}$ & & $\begin{array}{l}\text { Not } \\
\text { purtant } \\
\text { Find Out } \\
\text { | }\end{array}$ \\
\hline a. Where your parents save $\ldots \ldots \ldots \ldots \ldots \ldots$. & 2 & 3 & 4 & 5 \\
\hline b. Where your inends sove. . . . . . . . . . I & 2 & 3 & 4 & 5 \\
\hline c. How friendly bank tellere anc............. I & 2 & 3 & 4 & 5 \\
\hline d. What the interat ratey arc. . . . . . . . . . . 1 & 2 & 3 & 4 & 5 \\
\hline e. What the risk of an investment ts........ I & 2 & 3 & 4 & 5 \\
\hline $\begin{array}{l}\text { f. What the service charges are. . . . . . . . } 1 \\
\text { 8. Types of axcounts or investments }\end{array}$ & 2 & 3 & 4 & 5 \\
\hline 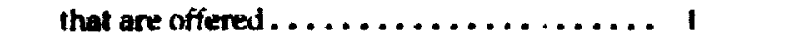 & 2 & 3 & 4 & 5 \\
\hline $\begin{array}{l}\text { h. What other services are offered } \ldots \ldots \ldots \ldots \text {. } \\
\text { 1. Repulation of the institution you are }\end{array}$ & 2 & 3 & 4 & 5 \\
\hline f. Type of insthtution (e.k. credit union & 2 & 3 & 4 & 5 \\
\hline vs. shartered bank $\ldots \ldots \ldots \ldots \ldots \ldots$ & 2 & 3 & 4 & $\mathbf{5}$ \\
\hline $\begin{array}{l}\text { k. The advertising of the institution....... } \\
\text { 1. How conventent it will be (n) sove }\end{array}$ & 2 & 3 & 4 & 5 \\
\hline with an irstitution . . . . . . . . . . . . . & 2 & 3 & 4 & 5 \\
\hline
\end{tabular}




\section{SLCIION D: BORROWINC}

The followitig yuusuons relate to how much money you burrow, from whom, what information you want before bornowing and from where you get this information.

16 How inuch money do you cumently owe, IN TOTAL, concraing all of your outstunding debts?

\section{$\mathbf{s}$}

17. Have you roer borrouned in the following ways? Answer YES or NO for each iten, and enter the amount you still otwe (as of totay) for each item for which now check YES

Amount Oured

2. Your fricends

b. Your parents

c. Your parents' credit cards:

Department sture cards

Visa, Mastercard, Amix

Cass stetien cards

d. Your own ciedit cards:

Department store cards

Visa, Mastexcard, Amex

Cas slation cards

e. Other credit cardx

(specify):

f. Bank luen:

G. Pawn brokers

h. Other (epecify):
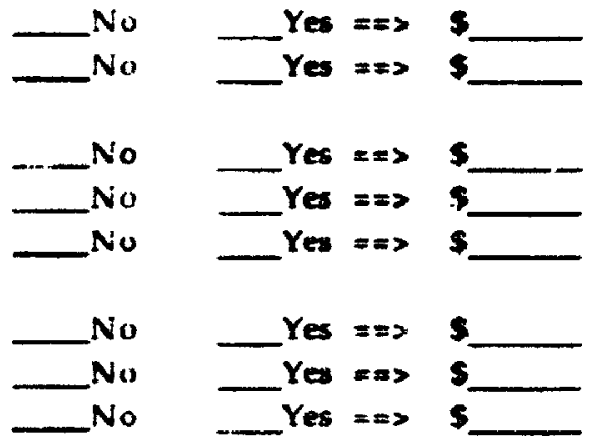

Yes $=\Rightarrow$

$N_{0}$
$N_{0}$
$N_{0}$

Yes $==>$
Yes $==>$
Yes $==>$
Yes $=2=>$

5

5

$\$$

No $\quad$ Yes $=2>\$$

If you have never weed a credit card (neither your own nor your parents') please check here . Skip questions 18 and 19, and go directly to queotion 20 on page 9. 
18. Did you buy anything for wourself with a credil iard lust month (October)! Ansurr YES or NO for ach isesn, and enter hura inut: you spent for each ifem for which you check YtS.

a. Your parints' credit cards Department store cards Visa, Mastercard, Amex Cas statuon cards

b. Your own credit cards Department slore cands Visa, Mastercard, Amex Cas station cards c. Other (specily).
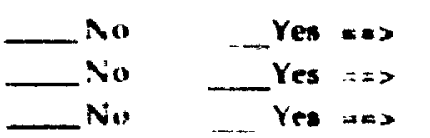

$\$$ $\mathbf{s}$ $\$$
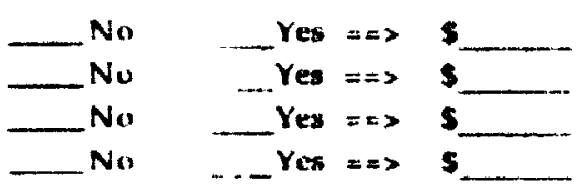

19 Please carcle the number that hest desirnbes the extenl to which you do the things listed below. If the statement is not applicable to you circle N/A.

2. I use my uwn credit card:

Never

1 regularly..............

b. 1 pay off the entire balance of any credit cards every munth. . I

c. I use my parents' credit cards regularty.

If I were tu use my parents' credit cards 1 would pay them back for the money 1 spent...

e. I pay my credit card bills with my parents' money.

f. 1 use credit cards unly becaure they are conventent. .........

81 use credit cards when I dou't have money to pay the bill. . . .

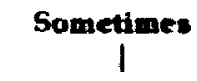

Alway 1

23

5

3 
20. Below are listed sane of $t^{*}$. thitgs that you might zwent to consider before using a credit card of your own. For each utem, check how unportant it would be for wu to find out atroul at before deciding to wse " credit card. When deciding how important euch is, think about how hard you would try to get the information if you did not hav it TYUL CAN ANSWER THIS QUESTION EVEN IF YOU DO NOT HAVE YOUR OWN CREDIT CARD NOW.)

a. What credit cards your
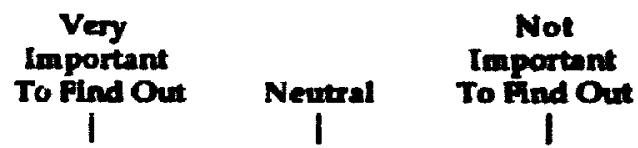

parents use............ 1 1 $2 \quad 3$

b. What credil cards your

friends use............. $1 \quad 2 \quad 3$

c. What the interest rates are.... 1140245

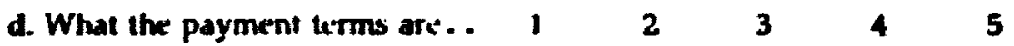

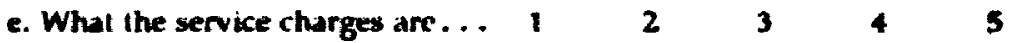

6. Reputation of the credil card

company............. $1 \quad 2 \quad 34$

g. How easy it is to get the

credit card............ 1 2 , 3

h. Whether or not you will have

the money to pay the bill.... $1 \quad 1 \quad 2 \quad 3 \quad 4 \quad 5$

i. Advertising of the credit cand

company............. 1424

21 Please chect whether you borrowed any momey last manth (Octaber), from the following sources. If you did, please write down how much you borrowed.

a. Your friends

b. Your parents

No

c. Bank loans

No

d Pawn brukuts

No

c. Other (specify)

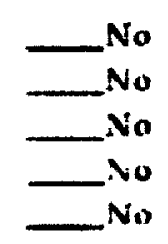

$\begin{array}{rl}\text { Yes }==> & \$ \\ \text { Yes }=x & 5 \\ \text { Yes }==2 & \$ \\ \text { Yes }==> & \$\end{array}$


22. Below are listed some of the things that people might isunt to consider before borrowng money from a particular pluce or from gurlisulur poople (excluding credit cards). For each ttem, check hors impurtan it unuld be for you lo find out about it ingore desiding to burrono. When dectding how important euch is, think ahout how hord you womble ary to get the information if you did not have it.

\begin{tabular}{|c|c|c|c|c|c|}
\hline & $\begin{array}{c}\text { Very } \\
\text { Important } \\
\text { To Find Out } \\
\mid\end{array}$ & & $\begin{array}{c}\text { Neutral } \\
\mid\end{array}$ & & $\begin{array}{l}\text { Not } \\
\text { portant } \\
\text { Mtid Out } \\
\text { | }\end{array}$ \\
\hline - Where your parents torrow . . . . . . . & 1 & 2 & 3 & 4 & $\mathbf{5}$ \\
\hline b. Where your irtends borrow . ........ & 1 & 2 & 3 & 4 & 5 \\
\hline c. What the interest rates are........ & 1 & 2 & 3 & $\mathbf{i}$ & $\mathbf{5}$ \\
\hline d. What the payment terms are...... & $\mathbf{i}$ & 2 & 3 & 4 & 5 \\
\hline e. What the service charges are...... & 1 & 2 & 3 & 4 & 5 \\
\hline f. Reputation of the lender. . . . . . . . & 1 & $\mathbf{z}$ & 3 & 4 & 5 \\
\hline 8. How easy it is tu bornow the money. . & 1 & 2 & 3 & 4 & 5 \\
\hline
\end{tabular}

23. Below are histed some of the places from twhich people nay borrowe movery. For EACH ONE (whether you haoc burrowed from that source or not) chect those peopte of things that you unuld rely on most for INFORMATION OR ADVCE byore borrowing momy is that wing. OYOU MAY CHECK MORE THAN ONE ANSWER IN EACH ROW).

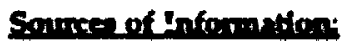

Bitond

\section{Salexporople}

Bantivition

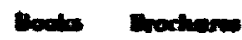

Conom Newapere edo

ronon Mortacese

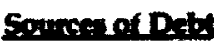

a Your own credit cards

Dept sture cards

Vist, Mastercard, Amex

Gas cards

b. Your parents' credit cards

Dept. store cards

Vist, Mastercard, Amex

Gas cards

c. Other credit cards

d. Bank luans

c Pawn brokers

f. Your friends

E Your parents

h. Other (specify):

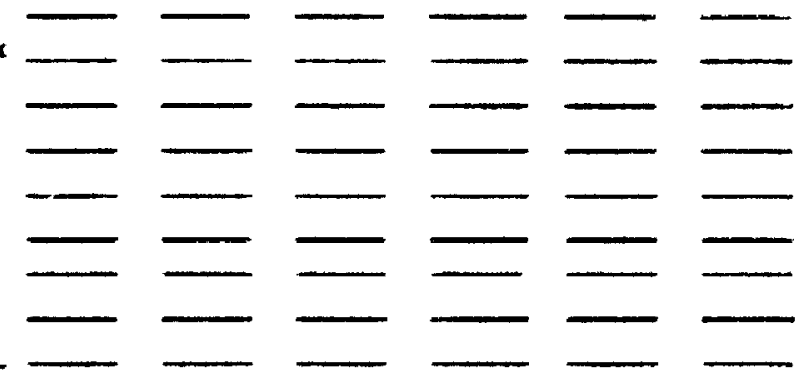


24. Beline are lisied sanse of the things that people might borrow money to buy. Write next to each item how much you hexe spent on it writhin the lase 6 months, und extimate the amunnt that you spent for cach iteril on a credit card and with ofher bormotwed moniy. ENTER O IF YOU HAVE NOT BOUCHT THE TTEM WTTHIN THE LAST G MONTHS.

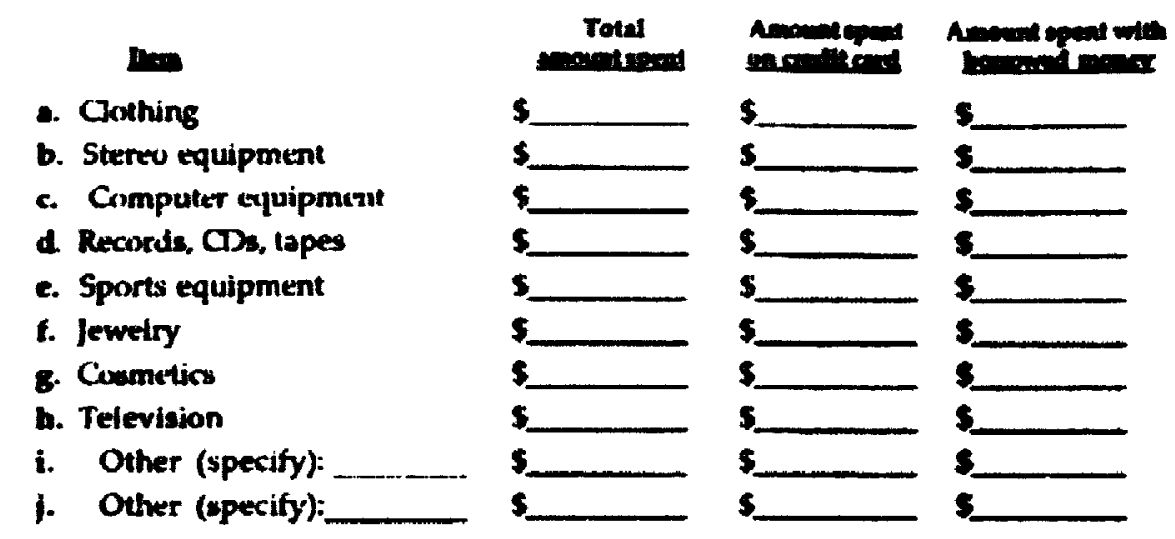

\section{SECTION P: DEMOCRAMHICS}

We need some demographic information about you to help us interpret this questionnire. To answer the following quentions please check the anower which best describes you or fill in the information requested.

25. What is your sex?

Female

Male

26. How old are you?

vears

27. Whet grade are you in?

10

11

12

28. What percentage of the time does your molker tive with you?

Percent

29. What percentage of the time dow your futher lix with you?

Petcent

30. How mony trothers and sisters do you have? 
31. Whut is your retigion?

\begin{tabular}{l} 
No religion \\
\hline Cathulic \\
\hline Protestant \\
\hline lewish \\
Other
\end{tabular}

32. How important is your religion to you?

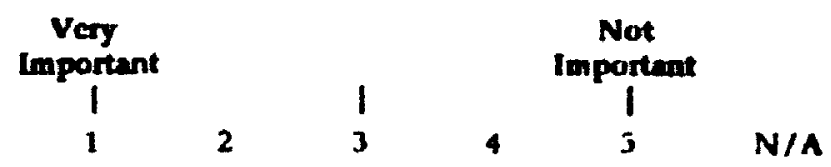

33. Please check the enswer that BIST describes:

Your MOTHEx'S edectionel becleground

High school or less Cummunity college Some university A univeraity degree Professional designation after universily Put-graduate degree(s)
You PaTtats duxational bedrgound

High school or leso Community college Sume univeralty A univerdity degrte Profecisional declignation after univervity Pout-yradunte degrea(s) 
34. Pleuse describe what your parents do for a living. The more specific you can oce the better. If they are no longer wording, plense describe what this did before thay slopped working.

\section{MOThER}

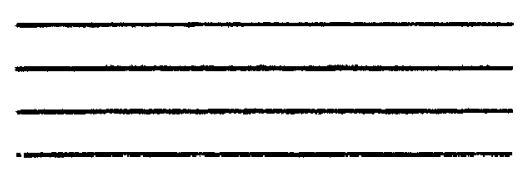

FATHER

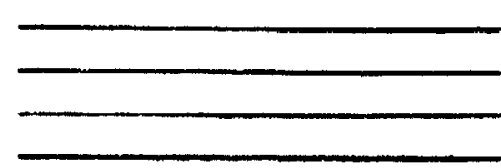

35. Please check the answer that best describes your annual fintly income (before laxes).

jess than 30,000

30,000 to 59,999

60,000 to 89,999

90,000 wo 119,000

120,000 and over

Don't know

Thank you for your help in filling out this questionuaine. Your cooperation is very much appreciated. 
Appendix C: Letter of Parental Consent 
Der tramonntian:

Nowates 9.1990

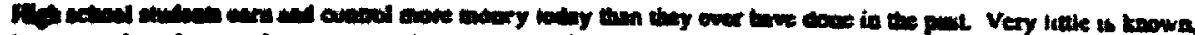

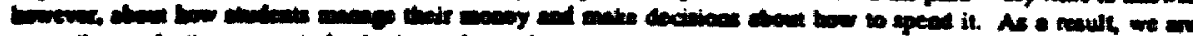

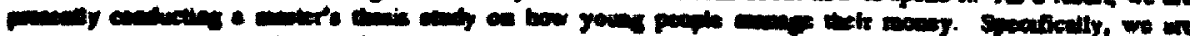

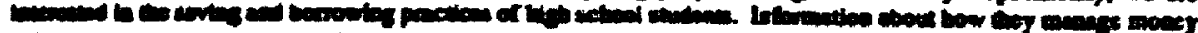

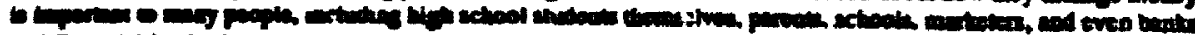

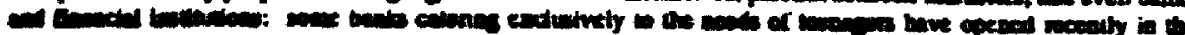
Unestim

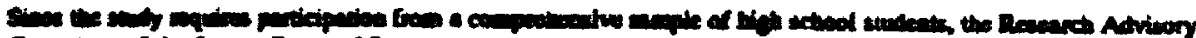

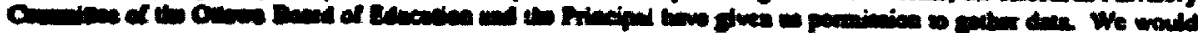

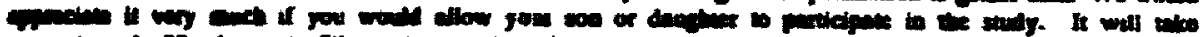

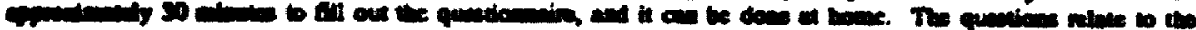

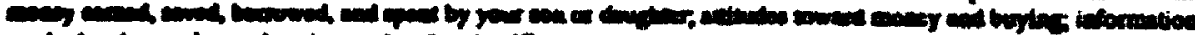

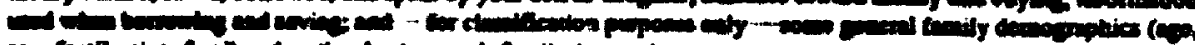

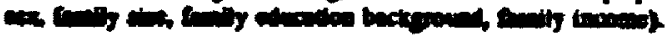

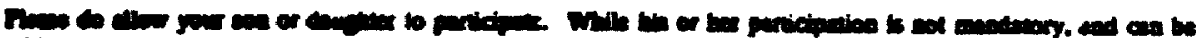

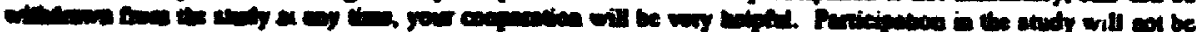

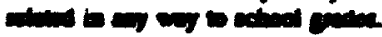

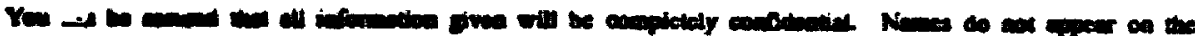

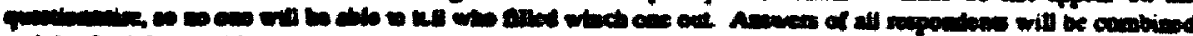

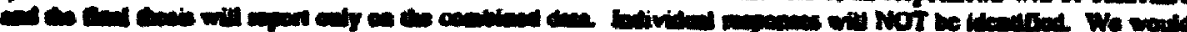

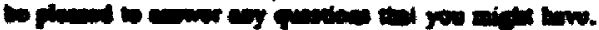

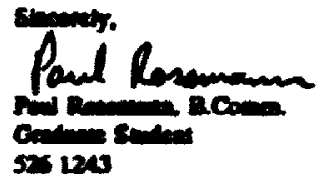

$$
\text { - Sucuixa havera.2p }
$$

Coments

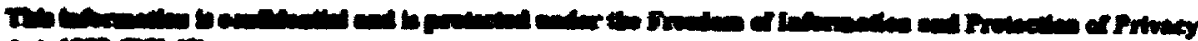
ascon

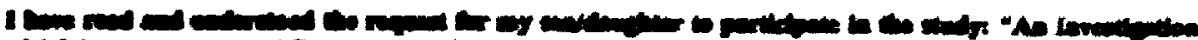

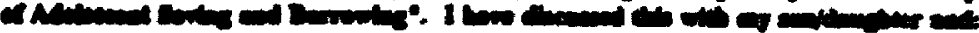

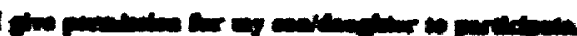

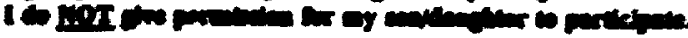

Name or snowert

an:

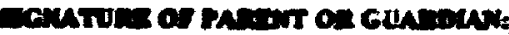

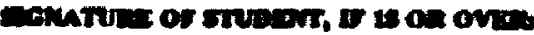

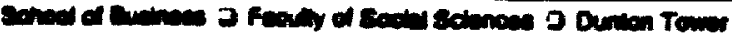

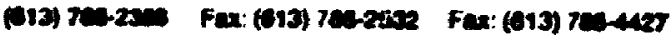


Appendix D: Table of Occupational Social Status 


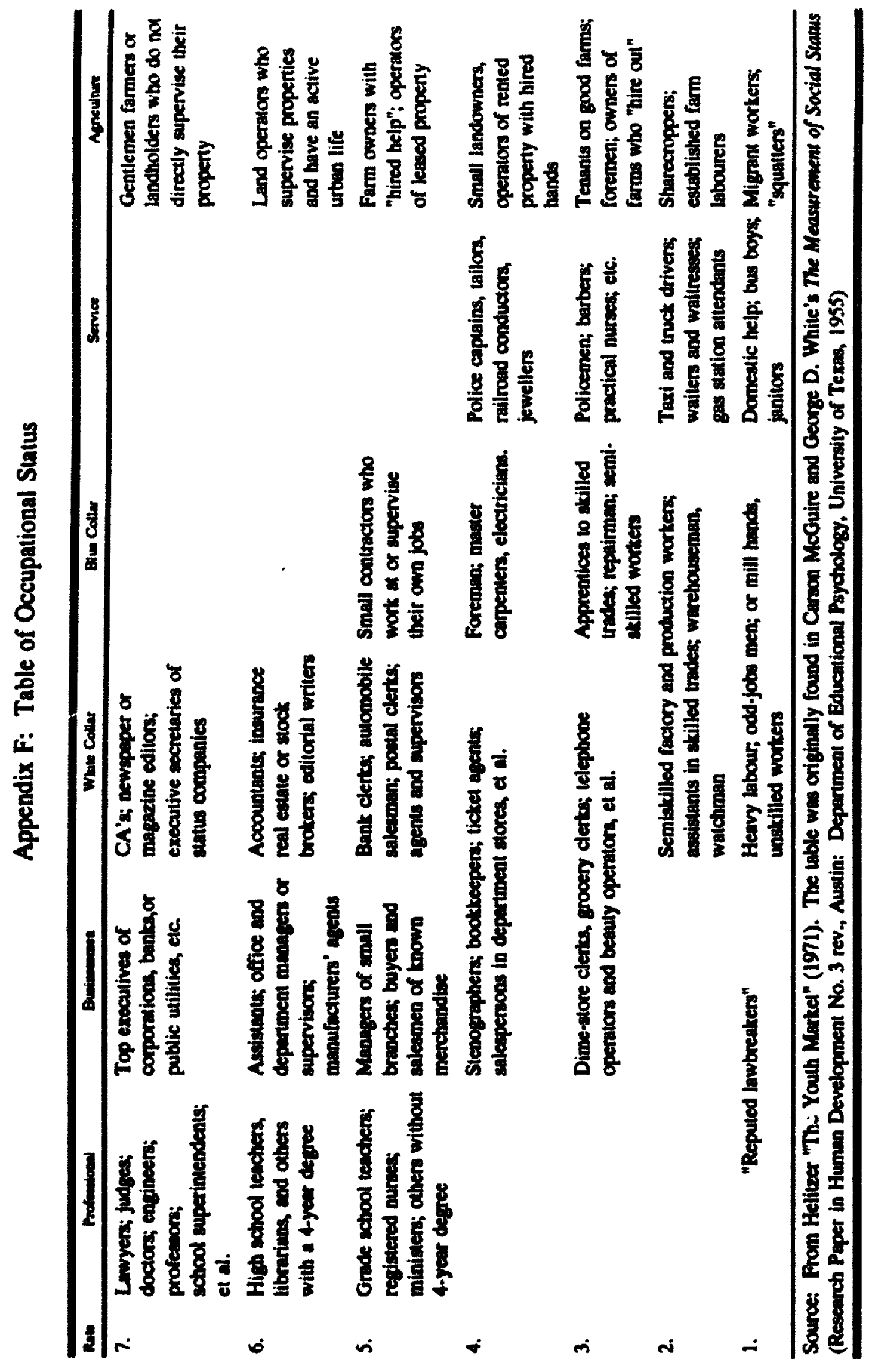


Appendix E: Research Schedule

Tasks

Proposal Preparation

Proposal Submission

Questionnaire Pretest

Data Analysis Preparation

Proposal defense

High School Clearance

Sample Selection

Sampling

Data Entry

Data Analysis

Thesis writing

Draft 1 Submission

Draft 2 Submission

Final Draft Submission

Thesis Defense

\section{Tine}

June 22 - September 15, 1992

September 15

September 15 - 30

September 15 - November 15

October 2

October 15

October 16 - November 15

November 5 - 31

November 17 - December 7

November 28 - December 14

January 14 - April 30

March 10

March 20

March 28

April 23, 1993 
Appendix F: Cost Schedule

Literature review

75.00

Proposal reproduction

25.00

Ethics Committee application

20.00

School board applications

50.00

Questionnaire reproduction

800.00

Data collection

130.00

Thesis reproduction

100.00

Participant foedback

25.00

Total

$\$ 1225.00$ 

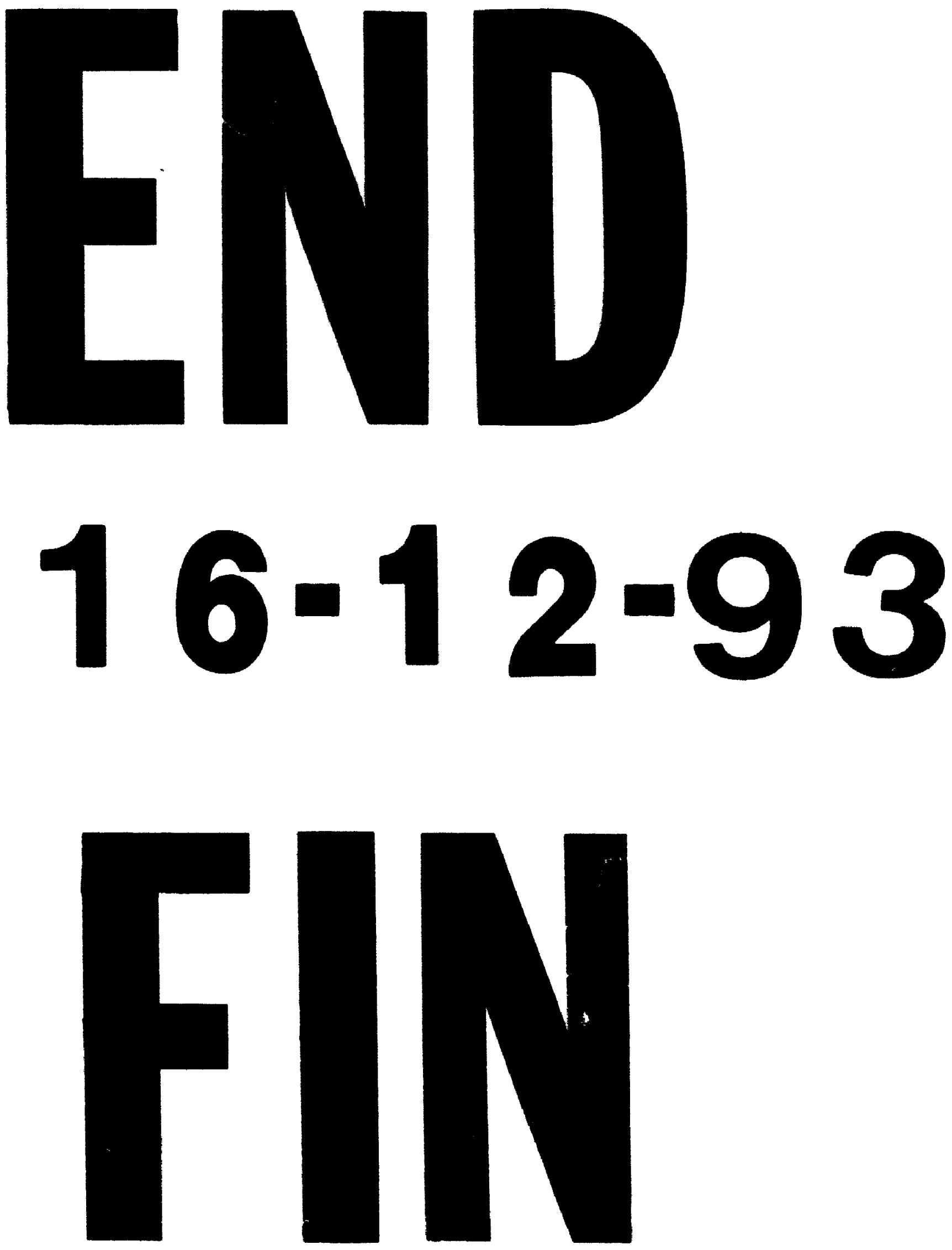